Prepared in cooperation with U.S. Joint Fire Science Program and National Interagency Fire Center, Bureau of Land Management, Great Northern Landscape Conservation, and Western Association of Fish and Wildlife Agencies

\title{
Restoration Handbook for Sagebrush Steppe Ecosystems with Emphasis on Greater Sage-Grouse Habitat- Part 3. Site Level Restoration Decisions
}

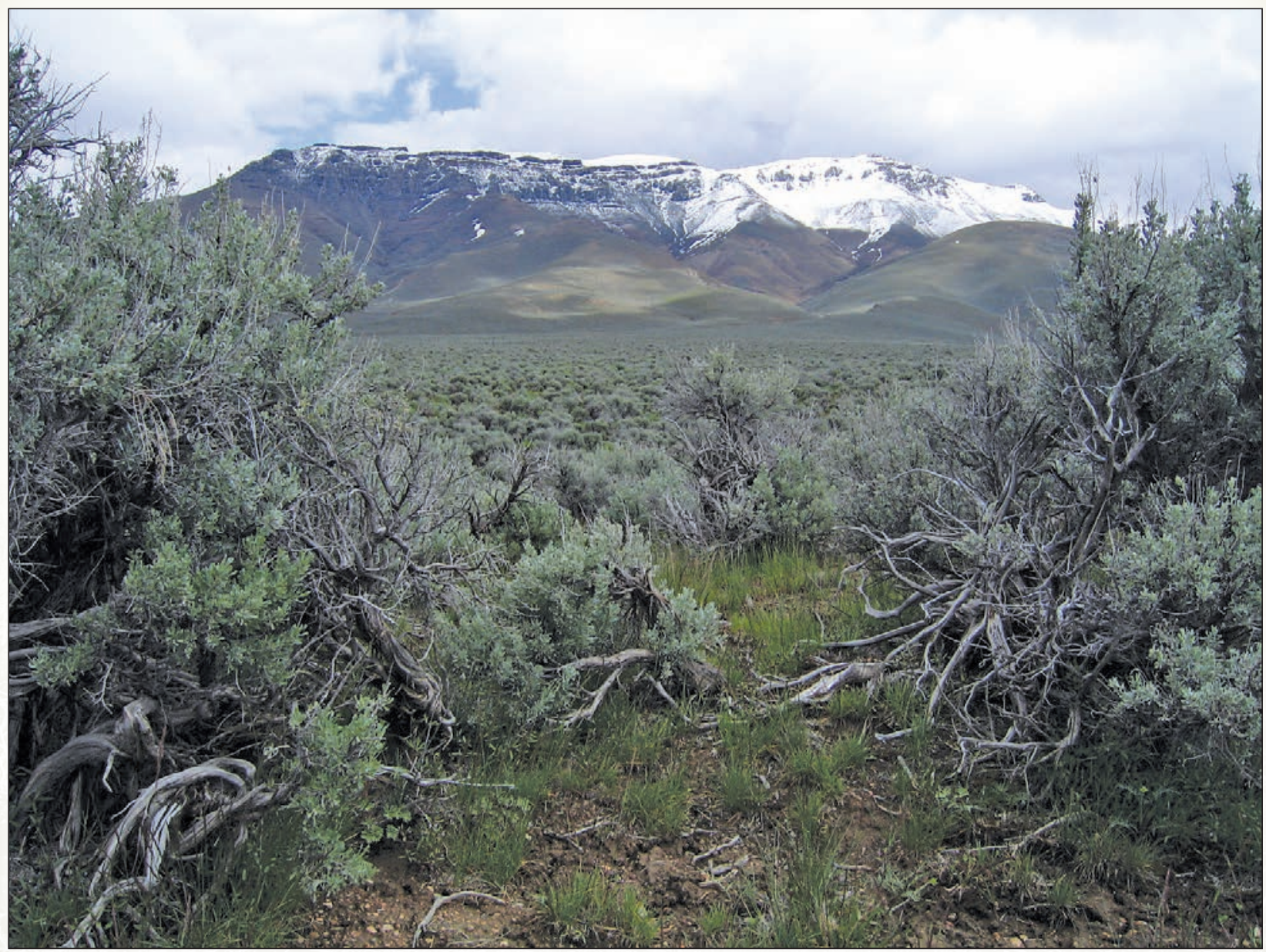

Circular 1426

Version 1.1, March 2018

U.S. Department of the Interior

U.S. Geological Survey 
Cover: Photograph showing Wyoming big sagebrush community near Winnemucca, Nevada. (Photograph by David Pyke, U.S. Geological Survey, 2005.) 


\section{Restoration Handbook for Sagebrush Steppe Ecosystems with Emphasis on Greater Sage-Grouse Habitat- Part 3. Site Level Restoration Decisions}

By David A. Pyke, Jeanne C. Chambers, Mike Pellant, Richard F. Miller, Jeffrey L. Beck, Paul S. Doescher, Bruce A. Roundy, Eugene W. Schupp, Steven T. Knick, Mark Brunson, and James D. Mclver

Prepared in cooperation with U.S. Joint Fire Science Program and National Interagency Fire Center, Bureau of Land Management, Great Northern Landscape Conservation, and Western Association of Fish and Wildlife Agencies

Circular 1426

Version 1.1, March 2018 


\title{
U.S. Department of the Interior SALLY JEWELL, Secretary
}

\author{
U.S. Geological Survey \\ Suzette M. Kimball, Director
}

\author{
U.S. Geological Survey, Reston, Virginia: 2017 \\ First release: 2017 \\ Revised: March 2018 (ver. 1.1)
}

\begin{abstract}
For more information on the USGS - the Federal source for science about the Earth, its natural and living resources, natural hazards, and the environment-visit http://www.usgs.gov or call 1-888-ASK-USGS.

For an overview of USGS information products, including maps, imagery, and publications, visit http://www.usgs.gov/pubprod/.
\end{abstract}

Any use of trade, firm, or product names is for descriptive purposes only and does not imply endorsement by the U.S. Government.

Although this information product, for the most part, is in the public domain, it also may contain copyrighted materials as noted in the text. Permission to reproduce copyrighted items must be secured from the copyright owner.

Suggested citation:

Pyke, D.A., Chambers, J.C., Pellant, M., Miller, R.F., Beck, J.L., Doescher, P.S., Roundy, B.A., Schupp, E.W., Knick, S.T., Brunson, M., and Mclver, J.D., 2018, Restoration handbook for sagebrush steppe ecosystems with emphasis on greater sage-grouse habitat—Part 3. Site level restoration decisions (ver. 1.1, March 2018): U.S. Geological Survey Circular 1426, 62 p., https://doi.org/10.3133/cir1426.

\section{Library of Congress Cataloging-in-Publication Data}

Names: Pyke, David A. | Joint Fire Science Program (U.S.)

Title: Restoration handbook for sagebrush steppe ecosystems with emphasis on greater sage-grouse habitat / prepared in cooperation with U.S. Joint Fire Science Program and National Interagency Fire Center, Bureau of Land Management, Great Northern Landscape Conservation, and Western Association of Fish and Wildlife Agencies.

Description: Reston, Virginia : U.S. Geological Survey, 2015- | Series:

Circular ; 1416, 1418 | Includes bibliographical references and index. Identifiers: LCCN 2015035308| ISBN 9781411339682 (pt. 1 : pbk. : alk. paper) | ISBN 9781411339972 (pt. 2 : pbk. : alk. paper)

Subjects: LCSH: Sagebrush steppe ecology--United States. | Steppe restoration--United States. | Sage grouse--Habitat--Conservation--United States.

Classification: LCC QH104 .R467 2015 | DDC 333.74/153--dc23

LC record available at http://lccn.loc.gov/2015035308

ISSN 1067-084X (print)

ISSN 2330-5703 (online) 


\section{Preface}

We organized this series on restoration leading the reader through concepts necessary to make decisions at the landscape and the site level for restoration of sagebrush (Artemisia spp.) steppe ecosystems. Most restoration projects within this ecosystem have historically been implemented to meet only site-specific objectives. Recently, the decision to not list the greater sage-grouse (Centrocercus urophasianus) as a threatened or endangered species was partially dependent on land managers making landscape- and site-level decisions for management actions including actions related to restoring habitat for this focal species. The sagebrush steppe ecosystem is one of the largest and most threatened ecosystems in the U.S. because of fires, invasive species, and human-influenced changes to ecosystem structure and function. The need for restoration far exceeds our means to restore all degraded habitats, but strategic decisions based on sound ecosystem knowledge and landscape principles may allow restoration to keep pace or exceed degradation in key locations to maintain wildlife populations dependent on these ecosystems.

This site-level tool is written so it might be used in conjunction with Part 2, landscape-level decision tool of the handbook on restoration of sagebrush steppe ecosystems (Pyke, Knick, and others, 2015) or as a stand-alone tool for any site within the sagebrush steppe. This tool relies on user understanding of a land unit resilience to disturbance and its resistance to invasive plants through soil-climate-plant relationships and it relies heavily on soil temperature and moisture regimes, soil descriptions, and ecological site concepts. These concepts were reviewed in Part 1 of the handbook on restoration of sagebrush steppe ecosystems (Pyke, Chambers, and others, 2015) and are intended as a reference for this site-level restoration decision tool. We encourage users to read and understand these concepts before applying this decision support tool. 


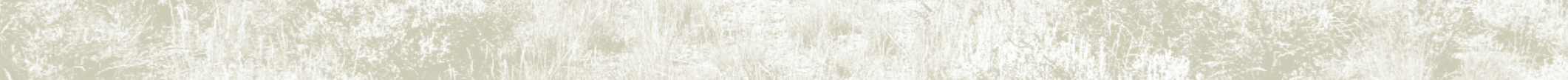




\section{Contents}

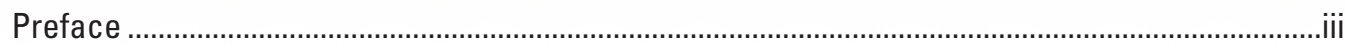

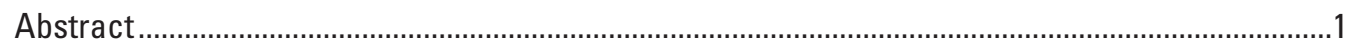

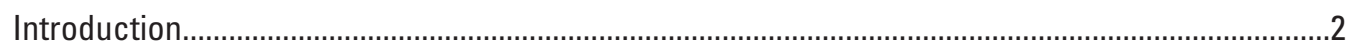

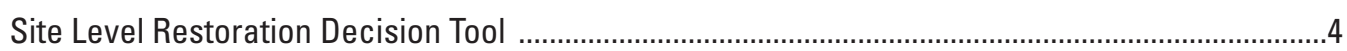

Step 1. What Are Site-Specific Management and Sampling Objectives for Restoration? .....4

Step 2. What Are the Ecological Site Characteristics of My Proposed Restoration Site?

Step 3. How Similar Is the Current Vegetation to That of the Plant Phases in the Reference State for the Ecological Site and Are There Potential Plant Intruders on the Proposed Restoration Site?. . .7

Step 4. Determine Land Use and Disturbance History ........................................................14

Step 5. Pre- and Post-Treatment Weather and Its Influence on Success .............................15

Step 6. Potential Restoration Treatment Types and Associated Impacts ...............................15

Step 7. Post-Treatment Grazing Management....................................................................... 41

Step 8. Implementation and Effectiveness Monitoring ...........................................................44

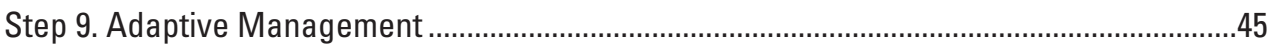

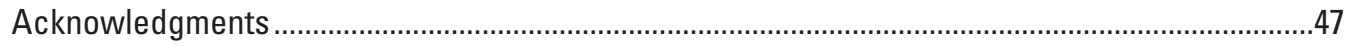

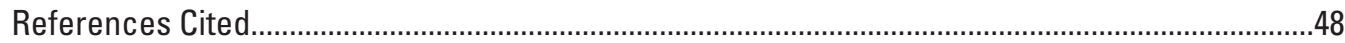

Appendix A. Generalized State and Transition Models...................................................................51

Appendix B. Score Sheet for Pre-Treatment Site Resilience to Disturbance and

Resistance to Invasive Annual Grasses in Sagebrush Steppe ............................................57

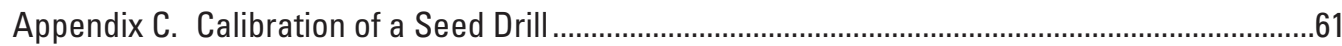

\section{Figures}

1. Map showing percentage of landscape sagebrush cover in the seven floristic provinces included in the sagebrush steppe.

2. Diagram showing hypothetical monitoring situation with three treatments and four monitoring units

3. Graph showing mean plant density and 95 percent confidence interval around the mean relative to a set management objective................................................................46

4. Diagrams showing simplified adaptive management for restoration decisions .............47 


\section{Tables}

1. Soil moisture regime names within upland sagebrush steppe ecosystems in Western United States and nomenclatural formative elements in official soil names, and the typical annual precipitation and humidity

2. Soil temperature regime names within upland sagebrush steppe ecosystems in Western United States and nomenclatural formative elements in official soil names, and typical mean annual soil temperature.

3. Generalized sagebrush ecological types

4. Characteristics of junipers and piñon pines used to separate pre-settlement from post-settlement stands in the Great Basin and Columbia River Plateau .....

5. Phases of juniper or piñon-juniper in-filling of sagebrush shrublands based on tree characteristics

6. Examples of perennial forbs and their tolerance to fire based on growth form .............12

7. Examples of woody plants and their tolerance to fire................................................13

8. Common herbicides used on rangelands for controlling vegetation................................24

9. Example of the calculations from the U.S. Geological Survey Bulk Seed Calculator .....33

10. Seeding recommendation for grasses, forbs, and shrubs provided by Monsen and Stevens $(2004$, p. 135)

11. Seeding recommendations for grasses, forbs, and shrubs provided by Lambert (2005, p. 87-91)

12. Recommended minimum number of growing seasons to defer defoliation to achieve restoration objectives.

13. Additional years of deferment of large animal herbivory beyond those cited in table 12

14. Years normally required to establish, mature, and flower provided these plants are not defoliated

15. Example of the elements necessary for an implementation monitoring checklist. 


\section{Conversion Factors}

U.S. customary units to International System of Units

\begin{tabular}{|c|c|c|}
\hline Multiply & By & To obtain \\
\hline \multicolumn{3}{|c|}{ Length } \\
\hline inch (in.) & 2.54 & centimeter $(\mathrm{cm})$ \\
\hline inch (in.) & 25.4 & millimeter (mm) \\
\hline foot (ft) & 0.3048 & meter (m) \\
\hline mile (mi) & 1.609 & kilometer (km) \\
\hline \multicolumn{3}{|c|}{ Area } \\
\hline square foot $\left(\mathrm{ft}^{2}\right)$ & 0.09290 & square meter $\left(\mathrm{m}^{2}\right)$ \\
\hline acre & 0.4047 & hectare (ha) \\
\hline \multicolumn{3}{|c|}{ Mass } \\
\hline pound, avoirdupois (lb) & 0.4536 & kilogram (kg) \\
\hline
\end{tabular}

International System of Units to U.S. customary units

\begin{tabular}{lcl}
\hline \multicolumn{1}{c}{ Multiply } & By & To obtain \\
\hline millimeter $(\mathrm{mm})$ & Length & \\
centimeter $(\mathrm{cm})$ & 0.03937 & inch (in.) \\
meter $(\mathrm{m})$ & 0.3937 & inch (in.) \\
kilometer $(\mathrm{km})$ & 1.094 & yard (yd) \\
\hline & 0.6214 & mile (mi) \\
\hline square meter $\left(\mathrm{m}^{2}\right)$ & Area & square foot $\left(\mathrm{ft}^{2}\right)$ \\
hectare (ha) & 10.76 & acre \\
\hline
\end{tabular}

\section{Datum}

Horizontal coordinate information is referenced to the North American Datum of 1983 (NAD 83). 



\title{
Restoration Handbook for Sagebrush Steppe Ecosystems with Emphasis on Greater Sage-Grouse Habitat- Part 3. Site Level Restoration Decisions
}

\author{
By David A. Pyke ${ }^{1}$, Jeanne C. Chambers ${ }^{2}$, Mike Pellant ${ }^{3}$, Richard F. Miller ${ }^{4}$, Jeffrey L. Beck ${ }^{5}$, Paul S. Doescher ${ }^{6}$, \\ Bruce A. Roundy ${ }^{7}$, Eugene W. Schupp ${ }^{8}$, Steven T. Knick', Mark Brunson ${ }^{9}$, and James D. Mclver ${ }^{10}$
}

\section{Abstract}

Sagebrush steppe ecosystems in the United States currently (2016) occur on only about one-half of their historical land area because of changes in land use, urban growth, and degradation of land, including invasions of non-native plants. The existence of many animal species depends on the existence of sagebrush steppe habitat. The greater sage-grouse (Centrocercus urophasianus) depends on large landscapes of intact habitat of sagebrush and perennial grasses for their existence. In addition, other sagebrushobligate animals have similar requirements and restoration of landscapes for greater sage-grouse also will benefit these animals. Once sagebrush lands are degraded, they may require restoration actions to make those lands viable habitat for supporting sagebrush-obligate animals, livestock, and wild horses, and to provide ecosystem services for humans now and for future generations.

When a decision is made on where restoration treatments should be applied, there are a number of site-specific decisions managers face before selecting the appropriate type of restoration. This site-level decision tool for restoration of sagebrush steppe ecosystems is organized in nine steps.

- Step 1 describes the process of defining site-level restoration objectives.

- Step 2 describes the ecological site characteristics of the restoration site. This covers soil chemistry and texture, soil moisture and temperature regimes, and the vegetation communities the site is capable of supporting.

- Step 3 compares the current vegetation to the plant communities associated with the site State and Transition models.

- Step 4 takes the manager through the process of current land uses and past disturbances that may influence restoration success.

- Step 5 is a brief discussion of how weather before and after treatments may impact restoration success.

- Step 6 addresses restoration treatment types and their potential positive and negative impacts on the ecosystem and on habitats, especially for greater sage-grouse. We discuss when passive restoration options may be sufficient and when active restoration may be necessary to achieve restoration objectives.

- Step 7 addresses decisions regarding post-restoration livestock grazing management.

- Step 8 addresses monitoring of the restoration; we discuss important aspects associated with implementation monitoring as well as effectiveness monitoring.

- Step 9 takes the information learned from monitoring to determine how restoration actions in the future might be adapted to improve restoration success.

\footnotetext{
${ }^{1}$ U.S. Geological Survey, Forest and Rangeland Ecosystem Science Center.

${ }^{2}$ U.S. Forest Service, Rocky Mountain Research Station.

${ }^{3}$ Bureau of Land Management.

${ }^{4}$ Eastern Oregon Agricultural Research Center, Oregon State University, Corvallis.

${ }^{5}$ Department of Ecosystem Science and Management, University of Wyoming, Laramie.

${ }^{6}$ Department of Forest Ecosystems and Society, Oregon State University, Corvallis.

${ }^{7}$ Department of Plant and Wildlife Sciences, Brigham Young University, Provo.

${ }^{8}$ Department of Wildland Resources and the Ecology Center, Utah State University, Logan.

${ }^{9}$ Department of Environment and Society and the Ecology Center, Utah State University, Logan.

${ }^{10}$ Eastern Oregon Agricultural Research Center, Oregon State University, Union.
} 


\section{Introduction}

Successful restoration at the site level requires a number of decisions that depend on past management, current conditions, financial and human resources, and project objectives. This site-level decision tool on restoration of sagebrush steppe ecosystems uses concepts regarding sagebrush ecosystem resilience to disturbance and resistance to invasive species, in addition to State and Transition models within ecological sites, to determine appropriate techniques and species for restoration. More detailed explanations of these concepts are presented in Part 1 of the handbook on restoration of sagebrush steppe ecosystems (Pyke, Chambers, and others, 2015). In addition, the use of resilience and resistance concepts to evaluate the potential for site recovery and restoration success is provided in a recent field guide by Miller and others (2014) and many of those concepts are incorporated into this site-level decision tool of the handbook on restoration of sagebrush steppe ecosystems. This site-level decision tool is intended to aid those planning a site-specific restoration project by stepping them through a series of questions or choices to select sites and matching techniques that meet project objectives and improve the potential for restoration success. We have incorporated many of the questions from the guide by Miller and others (2014) on site restoration, but we encourage readers to study that complete guide to obtain a full understanding of concepts they present.

This site-level decision tool is intended for use throughout the sagebrush biome, but some aspects of the decision process may relate more strongly to the Northern and Southern Great Basin, Columbia Basin, and Snake River
Plain floristic provinces (fig. 1) because of a greater focus on research and applications of restoration techniques in these areas. These provinces were selected for study because they have a high tendency to be invaded by annual grasses and to burn. In addition, ongoing woodland expansion into sagebrush shrublands is reducing the amount of shrubs, including sagebrush, and perennial grasses and forbs as a result of competition from the trees, and increasing the need for restoration following fire (Miller and others, 2000; Roundy and others, 2014). Since 1990, fires have become more frequent in the Wyoming Basin and the Silver Sagebrush floristic provinces of Wyoming and Montana (Miller and others, 2011; however, see Baker, 2013), and Mealor and others (2013) have documented annual grass dominance and risk within Wyoming. The seasonality of precipitation and relative dominance of warm and cool season plants have influenced both annual grass invasion and fire regimes in these areas (Bradford and Lauenroth, 2006; Bradley, 2009). As science provides more detail regarding similarities and differences between the Intermountain region and those regions farther east, improvements in this site-level decision tool may be implemented to aid in successful restoration.

This site-level restoration decision tool is structured in nine steps that may be most useful when steps are addressed sequentially. Each section has a primary question or statement followed by related questions and statements to assist the user in addressing the primary question or statement. Many of these steps may be accomplished proactively on an ecoregional basis, especially for the purpose of expediting treatments such as post-wildfire rehabilitations.

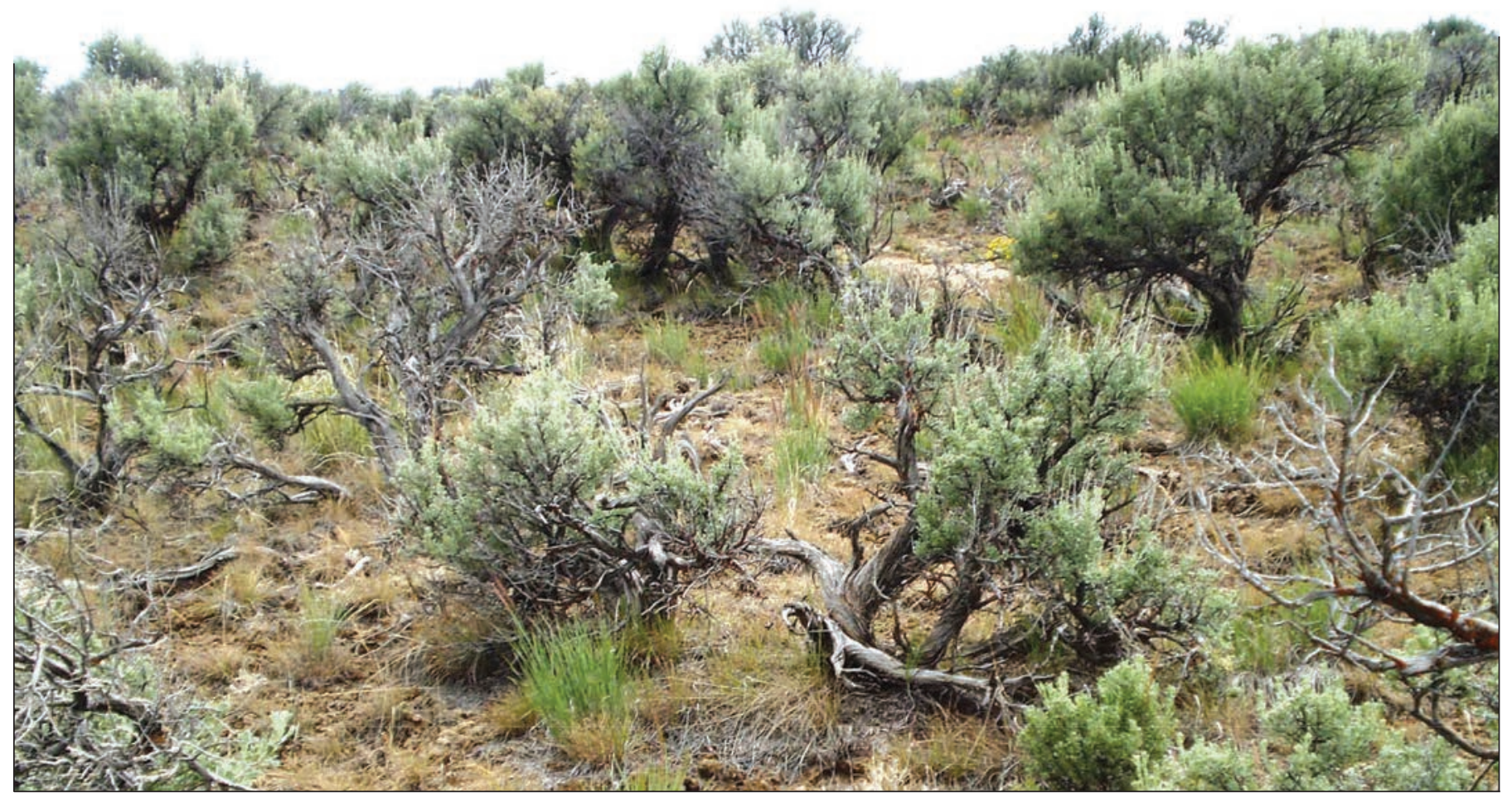

Native sagebrush stand near Elko, Nevada. 


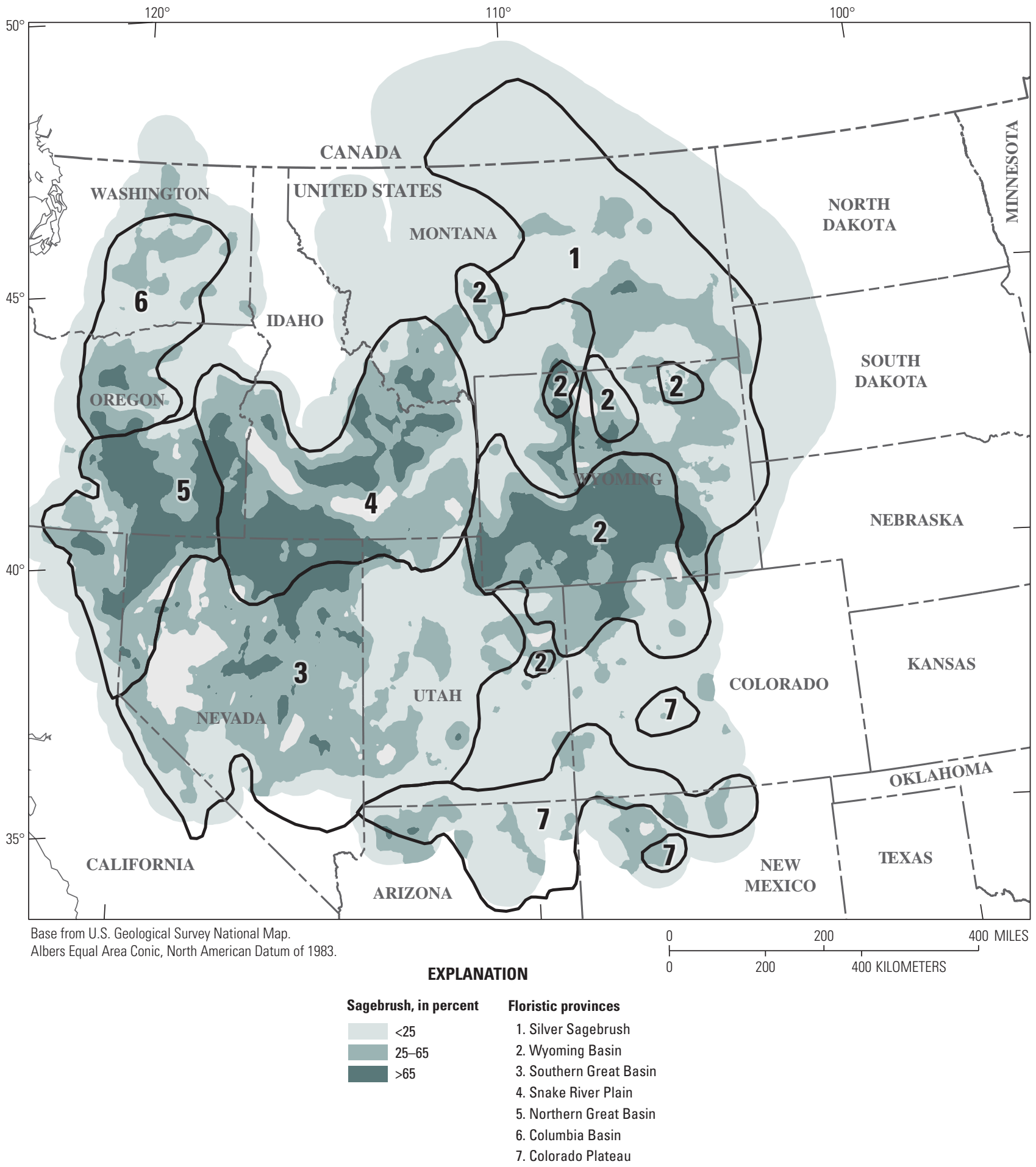

Figure 1. Percentage of landscape sagebrush cover in the seven floristic provinces included in the sagebrush steppe. The greater sage-grouse range is often divided into western (Columbia Basin, northern Great Basin, Snake River Plain, and southern Great Basin) and eastern regions (Silver Sagebrush, Wyoming Basin, and Colorado Plateau) (from Miller and others, 2011). 


\section{Site Level Restoration Decision Tool}

\section{Step 1. What Are Site-Specific Management and Sampling Objectives for Restoration?}

The conceptual connection between restoration objectives, treatments, and achievements is important for adaptive restoration management. This section uses Elzinga and others (1998) as the basis for setting restoration objectives. There are six components of a management objective (1-Species, group or indicator; 2-Location; $3-$ Attribute; 4-Action; 5-Quantity or status; 6-Time frame); the following list will lead managers through the development of specific site-level restoration objectives. Those objectives will contain appropriate attributes to measure during effectiveness monitoring (Step 8).

- What are the Target Species, Vegetation Groups, or Ecological Conditions (for example, Ground Cover, Plant Species or Group Density, or Vegetation Gaps) that will be measured to determine restoration success?

Targets for determining success can be a single species if that is what is being increased (for example, sagebrush) or decreased (for example, trees) during restoration. Targets also may include a grouping of species based on functional or structural attributes, such as perennial grasses, annual grasses, biological soil crusts, all vegetation, or an abiotic indicator such as bare ground or gaps among perennial plants. There may be multiple objectives, for example, reducing invasive species while increasing desirable perennial species. Each species, group, or indicator should be identified, described, and listed separately.

\section{-What is the location or geographic area?}

The area relates to the restoration site being treated. This is the area in which objectives and monitoring results are relevant, and what statisticians refer to as the area of inference. The area of inference should not expand beyond the area that is monitored unless multiple sites are being treated similarly and have similar environmental conditions or the environmental conditions will be included as a variable of the analyzed results. If individual restoration sites encompass multiple ecological sites, it may be useful to stratify the restoration area because each ecological site or treatment may be more or less effective relative to other ecological sites and treatments.

- What attribute will be measured on the species, group, or indicator to specify restoration success?

List and describe each measurement being made on the species, plant groups, or indicator(s) previously identified. Examples are cover, density, biomass, or distance.
- What action should successful restoration achieve?

This should be a verb that describes the direction of change that a successful restoration will produce. There are three basic actions: increase, decrease, or maintain.

- What is the measured quantity/status that will specify restoration success?

This is a critical element of the objective and requires thought to make certain the objective adheres to the Specific, Measurable, Achievable, Reasonable, and Tractable (SMART) objective concept. This element is critical to the achievable and reasonable aspect of this concept. As an example, the vision for a cheatgrass control project might be to eliminate cheatgrass, but that is probably not achievable or reasonable to expect that it can be done. Setting an objective for the measured cover of cheatgrass to be 10 percent less than the perennial herbaceous cover may be an achievable and reasonable value when attempting to control cheatgrass and increase perennial herbaceous vegetation. There are two types of quantitative objectives:

- Target/threshold quantities.-Targets are goals for species, functional/structural groups, or abiotic indicators. Thresholds are levels of measured attributes below which additional intervention or changes in management are needed. For example, a target or threshold goal for a seeding may be to establish two bluebunch wheatgrass (Pseudoroegneria spicata) plants per square meter. Reseeding may be initiated if this threshold is not achieved.

- Change/trend quantities.-These are generally comparisons between conditions that may relate quantities in treated areas to those in pre-treatment areas or to those in an untreated area located within the treatment area (an untreated control). These untreated areas are useful because they also reflect how species, functional/structural groups, or indicators would have responded without an intervention. Generally, change/ trend quantities are specific to an ecological site and are listed as proportional (percentage) changes relative to the pre-treatment or untreated values (for example, cover of perennial grasses in seeded areas will increase by 10 percent over the cover of perennial grasses in untreated areas).

-What is the timeframe needed to achieve this objective?

Again, this contributes to the achievable and reasonable component. Adequate time should be allowed for the objective to be achieved. Ecological timeframes require flexibility in our expected management timeframe for 
achieving objectives. If weather conditions during the monitoring timeframe impact plant growth, then more or less time might be required to achieve objectives. For example, current information on responses of cheatgrass and other invasive annual grasses after fire may lead managers to anticipate a decrease in cover in the first year after a fire, but an increase greater than pre-fire levels by year three that may not decrease until years six to eight even with an established, resilient plant community. Therefore, control objectives for these invasive annual grasses without herbicide applications may require a minimum of 6 years for the response to be observed. In addition, invasive annual grass cover may fluctuate depending on the timing and amount of precipitation. Pay attention to weather conditions and how they may influence annual plant cover. Trend measurements inherently will have multiple periods in which monitoring is conducted and trends are documented for the target measurements. Trend objectives could have a combination of objectives where one examines the directionality and size of the measurement change over a regular timeframe (for example, 1 percent decline or more in cover per year over 5 years) while the other objective may be a threshold level within the same period (for example, 5 percent decline in cover occurring anytime in a 5 -year period). Monitoring should be continued long term to ensure that the original restoration objectives are maintained. If they are not maintained, corrective management actions can be taken before the integrity of the original project is degraded or lost.

- Sampling precision and power to detect a change if the objective is met.

This often concerns people, causing them to not conduct quantitative monitoring because it dictates how many samples are necessary, but this should not be the case. Monitoring designs are based on observer ability to detect a given level of change with a desired certainty over a specific length of time. When people take classes in statistics, they are often taught to be highly confident ( $>90$ percent confidence) that the average measured value with its confidence limits will represent the actual (true) average. This high degree of confidence (also known as power) drives up the number of samples that are necessary. In monitoring restored vegetation, this high degree of precision can often be reduced to a 75 or 80 percent confidence, reducing the number of samples to an achievable number. Another way to reduce the level of samples needed while maintaining a 75 or 80 percent confidence is to group species for measurements. For example, instead of attempting to achieve a level of cover for one species of perennial grass, all perennial grasses may be grouped together.

\section{Step 2. What Are the Ecological Site Characteristics of My Proposed Restoration Site?}

Ecological sites are the basic component of a land-type classification system that describes ecological potential and ecosystem dynamics of land areas. An ecological site is defined as a distinctive kind of land with specific soil and physical characteristics that differ from other kinds of land in its ability to produce a distinctive kind and amount of vegetation and its ability to respond similarly to management actions and natural disturbances. Physical factors include soils, climate, hydrology, geology, and physiographic features. Biotic factors include plant species occurrence, plant community composition, annual biomass production, wildlife-vegetation interaction, and other factors (http://www. nrcs.usda.gov/wps/portal/nrcs/detail/national/landuse/rangep asture/?cid=stelprdb1068392, accessed December 27, 2016). If assistance is needed in determining the ecological site for your area, contact the rangeland management specialist or soil scientist at the local Natural Resource Conservation Service (NRCS) office.

\section{- Soils.}

Obtain the soil survey or go to web soil survey (http:// websoilsurvey.sc.egov.usda.gov/ accessed December 27, 2016) to determine the mapped soils for the restoration site. Refer to Part 1 of this restoration handbook for sagebrush steppe ecosystems (Pyke, Chambers, and others, 2015) for details on the following terms and how to determine them.

- Potential soil map units.--Determine the soil map unit names and the soil map unit components for each map unit at the restoration site.

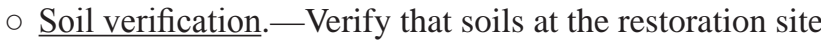
match the description of soils mapped for the location. Dig several holes in representative areas at least 20 in. $(50 \mathrm{~cm})$ deep or until you can no longer dig because of bedrock or hardened parent material, whichever comes first. Stones must be dug out of the holes. Bedrock or a root-restricting layer (for example, petrocalcic horizon) will stop the digging and determine soil depth.

- Does the soil surface texture match the map unit descriptions? Does the surface texture and descriptors from the Soil Map Unit component description match what is found in the surface horizon?

- Does the soil depth match? Does the depth to a root restriction horizon match the description? 
- Is there calcium carbonate in soil and if so, how strong is it? Place drops of 0.1 normal solution of hydrochloric ( $\mathrm{N} \mathrm{HCl}$ ) acid on the soil at different soil horizons and depths and determine if the acid effervesces. The strength of the effervescence indicates amount of calcium carbonate in that part of the soil.

- Are soils alkaline? Highly effervescent soils (also known as limey soils) are generally alkaline (much higher than neutral $\mathrm{pH} ;>7.0$ ).

If your answers to the previous questions match the soil description, then your site probably matches the map unit component and the ecological site correlated to the soil map unit. Additional verification can be determined in matching additional landscape conditions. Some states in the U.S. have keys to ecological sites that may assist in this verification process and should be used when available. If the soils do not match, then look at the typical soil inclusions occurring at this soil map unit to determine if one of these soils better matches the site. If so, then use the ecological site description associated with that soil. If none of the inclusions match, then it will require some investigation to determine the correct soil. In such cases, it may be quicker to employ the services of a local soil scientist to assist in identifying the appropriate soil and ecological site.

○ Ecological sites.-For each known soil map unit component, determine the correlated ecological sites; there may be more than one ecological site if the soil map unit has multiple soil map unit components.
- Soil moisture and temperature regimes.

Soil surveys also include information on soil moisture and temperature regimes. NRCS has assembled spatial data depicting soil temperature and moisture classes across greater sage-grouse (Centrocercus urophasianus; hereinafter, sage-grouse) management zones (available through the Landscape Conservation Management and Analysis Portal accessed December 5, 2016, at http:/greatnorthernlcc.org/lcmap) to provide an initial approximation. Because soil moisture and temperature estimates summarize data and conditions across large regions, specific site conditions may not precisely reflect the mean values provided in soils data. Thus, these values are a starting point, and should be further validated with the following soils information.

o Determine the soil moisture regime (table 1 ). The soil moisture regime names occur as formative elements of the soil series name.

○ Determine the soil temperature regime (table 2). Soil temperature regime names are easily found in soil nomenclature because the full name is often used (with the exception of Cryic).

\section{- Potential vegetation.}

Ecological site descriptions list the major plant species and range of composition based on their potential annual production or canopy cover within at least one of the plant community phases of the reference state (Step 3). These also will provide some initial ideas for species that may be restored on the area (Step 6) and their relative abundances that might be attained.

Table 1. Soil moisture regime names within upland sagebrush steppe ecosystems in Western United States and nomenclatural formative elements in official soil names, and the typical annual precipitation and humidity.

[Abbreviations: cm, centimeter; in., inch]

\begin{tabular}{|l|l|l|}
\hline \multicolumn{1}{|c|}{$\begin{array}{c}\text { Moisture } \\
\text { regime name }\end{array}$} & \multicolumn{1}{|c|}{$\begin{array}{c}\text { Formative elements } \\
\text { for nomenclature }\end{array}$} & \multicolumn{1}{c|}{ Typical annual precipitation and humidity } \\
\hline Aridic or Torric & -id; -ic; arid-; torr-; anhy- & Less than 12 in.; Dry-Aridic or torric is less than 10 in. (25.4 cm); Dry summers \\
\hline Xeric & Xer- & $\begin{array}{c}10-14 \text { in. }(25.4-36.6 \mathrm{~cm}) \text {; Moist Xeric meet the definition for Xeric but has greater than } \\
14 \text { in. }(36.6 \mathrm{~cm}) ; \text { Dry summers }\end{array}$ \\
\hline Ustic & Ust- & Exceeds 14 in. $(36.6 \mathrm{~cm}) ;$ Humid summer \\
\hline
\end{tabular}


Table 2. Soil temperature regime names within upland sagebrush steppe ecosystems in Western United States and nomenclatural formative elements in official soil names, and typical mean annual soil temperature.

[Typical mean annual soil temperature: Temperatures taken at 50 centimeters (19.6 inches) depth or at deepest point if less than 50 centimeters]

\begin{tabular}{|l|l|l|}
\hline \multicolumn{1}{|c|}{$\begin{array}{c}\text { Temperature } \\
\text { regime name }\end{array}$} & $\begin{array}{c}\text { Formative } \\
\text { for noments } \\
\text { formenclature }\end{array}$ & Typical mean annual soil temperature \\
\hline Cryic (cold) & Cry- & Less than $8^{\circ} \mathrm{C}$ with no permafrost and less than $15^{\circ} \mathrm{C}$ during summer months (June-August) \\
\hline Frigid (cool) & Not applicable & $\begin{array}{l}\text { Less than } 8{ }^{\circ} \mathrm{C} \text { with no permafrost and the differencebetween mean summer (June-August) and } \\
\text { winter (December-February) is greater than } 6{ }^{\circ} \mathrm{C}\end{array}$ \\
\hline Mesic (warm) & Not applicable & $\begin{array}{l}\text { At least } 8{ }^{\circ} \mathrm{C} \text {, but lower than } 15^{\circ} \mathrm{C} \text { and the difference between mean summer and winter is } \\
\text { greater than } 6{ }^{\circ} \mathrm{C}\end{array}$ \\
\hline
\end{tabular}

\section{Step 3. How Similar Is the Current Vegetation to That of the Plant Phases in the Reference State for the Ecological Site and Are There Potential Plant Intruders on the Proposed Restoration Site?}

Compare the composition of the current vegetation community with that of the appropriate community phase in the reference state of the State and Transition (S\&T) model for this ecological site (see appendix A for general models).

- Does the current plant community composition match or nearly match any of the community phases in the reference state?

The presence of invasive annual grasses in a community will place that community phase into an invaded state and not the reference state. Sites that nearly match the reference state, but are in an invaded state would have native perennial plant compositions (both species richness and relative dominance [cover or production]) that nearly match those of community phases in the reference state. Invasive annual grass composition, however, should be near or below 5 percent vegetation composition to be considered similar to the reference state. The perennial grasses should clearly dominate the plant composition or codominate with shrubs and should be represented by the appropriate mix of species based on the ecological site description.

- If the current plant community matches or nearly matches one of the plant community phases described in the reference state of the S\&T model, then likely your desired plant community will be one of these potential community phases.
- There are three options: (1) continue the existing management to maintain the existing community; (2) modify management (passive restoration) to achieve an alternative community phase using the community pathway as your guide; (3) implement an active restoration method, (for example, prescribed fire) to achieve an alternative community phase using the community pathway as your guide.

- If the current plant community does not match or nearly match one of the community phases in the reference state, this generally indicates that the current plant community is in an alternative stable state.

- These communities often lack resilience and are often dominated by invasive species or may have experienced tree encroachment from upslope and they lack plants and potential propagules for adequate natural recovery. These communities will require active restoration approaches to achieve plant community objectives.

We provide more detail here on major plant functional or structural groups that occur in plant communities of sagebrush ecosystems and whether they currently dominate the plant community or how they characterize the current vegetation of the community.

- Shrubs.

Should sagebrush or any other shrubs dominate or codominate this site in any community phase of the site S\&T model?

- Should shrubs dominate and, if not, should they even be present at the site? 
- If shrubs are not present and should exist, then restoration may be necessary. If shrubs are present, but only in small numbers and widely scattered across the site, then you must decide whether shrubs are in adequate density to reestablish naturally at desired levels to meet vegetation goals within the timeframe of your objective. If not, then you should consider restoration.

\section{- Perennial grasses.}

Are perennial grasses near the level of community composition and density that is expected for this ecological site? Perennial grasses that do not meet these criteria are at high risk of invasive annual grass dominance.

$\circ$ Are most of the potential dominant perennial grass species found at the site?

- Are the perennial grasses in the relative proportions that the ecological site description depicts?

- Do the perennial grasses achieve a combined total of 20 percent or more foliar cover?

$\circ$ Does the density of deep-rooted perennial grasses meet minimum densities depending on the site?

- The minimum densities are at least two plants per $10 \mathrm{ft}^{2}$ (about $1 \mathrm{~m}^{2}$ ) for xeric and at least three per $10 \mathrm{ft}^{2}\left(1 \mathrm{~m}^{2}\right)$ for aridic sites.

- Perennial forbs.

Is the relative abundance of perennial forbs near the level that is expected for this ecological site? Perennial forbs generally make up a small amount of cover (less than 5 percent canopy cover) in sagebrush steppe communities; they never dominate the plant community in the Great Basin, but representative species should be present. If perennial forbs do not fit the following listed criteria, then including perennial forbs in a restoration project would be encouraged, especially since forbs may provide direct food for sage-grouse or they provide habitat for insects that are food for sage-grouse or are food sources for pollinators.

- Are some of the perennial forb species present at the site also described in the ecological site description?

- Are there perennial forb species at the site that are known to be sage-grouse food?

$\circ$ Are the forbs that are present, insect pollinated?
- Are forbs of cultural values to humans (for example, medicinal, food, or religious functions) that would be expected to be present at the site?

- Do those perennial forbs that are present at the site represent greater than 1 percent of the cover (canopy or foliar)?

- Invasive plants with an emphasis on annual grasses.

When evaluating the current status of invasive species at the site, keep in mind the current drought conditions; cover of annual plants may be lower in dry years than in moister years. Additionally, it is important to evaluate not only the present status of the site, but also the inherent potential for the site to become invaded (resistance of site to invasive annual grasses) as well as the proximity of invasive plants, especially annual grasses, surrounding the site.

$\circ$ Do invasive plants dominate or codominate the site?

○ Is there a nearby seed source for invasive plants?

- Based on table 3, what is the relative level of potential resilience and resistance given the soil temperature and moisture regimes.

- If you have a cheatgrass risk model that applies to your site, is the risk low, moderate or high?

- Compare the current perennial grass cover to that of invasive annual grass cover.

- If perennial grass cover is greater than invasive annual plant cover, then perennial grasses may provide adequate competition to resist invasion.

- If the grass cover of perennials and invasive annuals species are nearly equal, then the risk of invasive annual plant dominance is high.

- If invasive annual plants already dominate then an alternative stable state represented by the invasive plants likely exists.

\section{- Tree encroachment.}

Tree encroachment generally refers to juniper or piñon pine (Juniperus sp. and Pinus sp.) species in sagebrush ecosystems, but may include other conifers (for example, Douglas fir [Pseudotsuga menziesii] in western Montana [Heyerdahl and others, 2006]). Since juniper and piñon pine species impact a greater portion of the sagebrush steppe, this section will emphasize their effects on restoration decisions. What are the characteristics of the tree stands or former tree stands? Use Miller and others (2014, p. 19-22 and appendix 4a, 4b, and 9) to guide your answers to the following questions. 
Table 3. Generalized sagebrush ecological types.

[Based on soil temperature and soil moisture regimes, typical characteristics, and resilience to disturbance and resistance to invasive annual grasses. Modified from Miller and others, 2014. Abbreviations: cm, centimeter; in., inch]

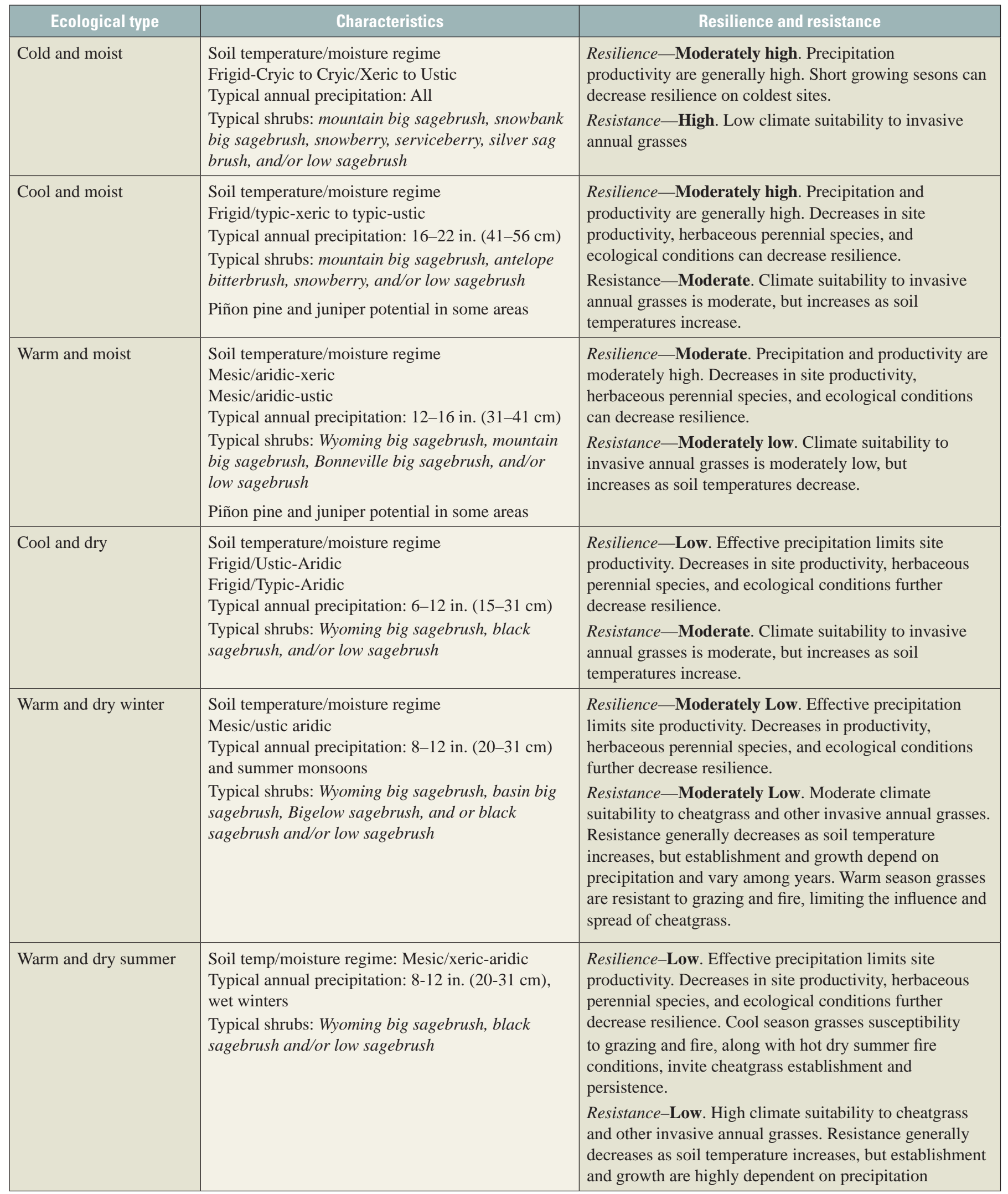


o Determine whether the stand is old growth or contains patches of old growth. If so, consider whether treatment is appropriate by answering the following questions:

- What is the age structure of live trees based on morphology (table 4)?

- Are there large stumps, large burned snags or logs indicating mortality of large trees from a past fire? If yes, would the projected tree cover of live and dead trees result in an open savanna ( $<10$ percent cover) or a woodland ( $>10$ percent cover)?
- What is the distribution of old trees across the treatment area? Are they in small patches on specific soils (soil restricted), or landscape positions (fuel limited areas), or do they occur across the majority of the area (potential encroachment)? Old growth stands of juniper or piñon are unlikely habitat for sagegrouse and may not make good habitat in the future, therefore, treatments to remove old growth trees to provide sage-grouse habitat may not be warranted.

- If trees appear to be young (post-settlement) and have dispersed into a sagebrush stand, then answer the following questions to determine if treatment is warranted.

Table 4. Characteristics of junipers and piñon pines used to separate pre-settlement from post-settlement stands in the Great Basin and Columbia River Plateau.

[Modified from Miller and others, 2014. A bbreviations: cm, centimeter; in., inch]

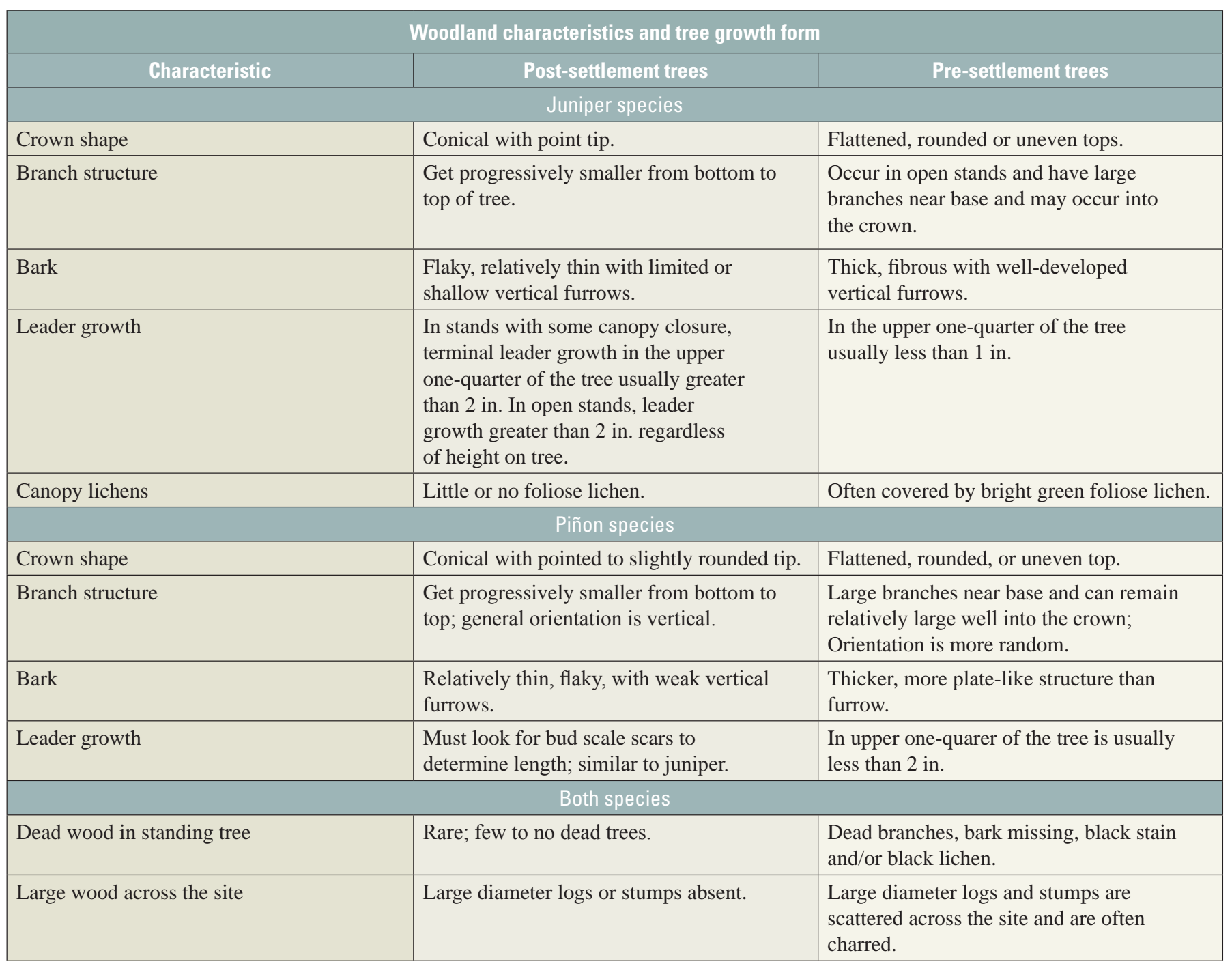


- What is the woodland encroachment phase (I, II, or III) based on tree characteristics (table 5)? Treatments in Phase I and II are more likely to result in increases in herbaceous and shrub species, but Phase III treatments may require additional revegetation to recover.

- How will density and size of trees influence fire behavior and how would fire impact the plant community composition (severity)? The more severe the fire, the less likely recovery will happen without assistance, therefore restoration may be necessary.

- How will fuel structure influence treatment selection and the ability to use fire? Low amounts of fine fuels or discontinuous fuels (for example, fine fuels only under tree canopies leaving intercanopy areas void of fuel) may make it difficult to carry a fire under controllable conditions.

- Are perennial grass and forb cover in the large interspaces between trees depleted (less than 10 percent canopy cover of herbaceous plants)? If so, fire may reduce their recovery after tree removal treatments.
- Is there high shrub mortality based on standing dead shrub plants or persistent shrub litter on the soil surface? If so, this may be a potential indicator of tree-induced resource limitations killing shrubs.

- Are there obvious signs of rill or sheet water erosion that exceed levels expected on the site (see ecological site description reference sheet for Rangeland Health)? If so, the site is experiencing or has experienced recently accelerated soil erosion. Determine if there is adequate top soil to support plants occurring in the reference state of the ecological site description.

- What is the distance to the nearest piñon or juniper seed source if a treatment is conducted? Rodents and birds disperse seed and most seeds are transported within $300 \mathrm{ft}(91 \mathrm{~m})$ of existing trees, but some birds may transport them as far as $3 \mathrm{mi}(4.8 \mathrm{~km})$.

- When considering fire to remove trees, what is the fire tolerance of the other plant species on the site (tables 6 and 7)?

- Most grasses tolerate fire well unless they have dense tillers or litter and standing dead material around the grass crown (see Miller and others, 2014).

Table 5. Phases of juniper or piñon-juniper in-filling of sagebrush shrublands based on tree characteristics.

[Modified from Miller and others, 2014. Abbreviations: cm/yr, centimeter per year; in./yr, inch per year]

\begin{tabular}{|c|c|c|c|}
\hline \multirow{2}{*}{ Characteristics } & \multicolumn{3}{|c|}{ Phases of juniper or piñon-juniper woodland in-filling } \\
\hline & Phase I (early) & Phase II (middle) & Phase III (late) \\
\hline $\begin{array}{l}\text { Tree canopy percentage of } \\
\text { maximum potential cover }\end{array}$ & Less than $1 / 3$ of maximum & $1 / 3$ to $2 / 3$ of maximum & Greater than $2 / 3$ of maximum \\
\hline $\begin{array}{l}\text { Leader growth of } \\
\text { dominant trees, in/yr } \\
(\mathrm{cm} / \mathrm{yr})\end{array}$ & $\begin{array}{l}\text { Terminal: Greater than } 4 \text { in. } \\
(10 \mathrm{~cm}) \\
\text { Lateral: Greater than } 4 \text { in. }(10 \mathrm{~cm})\end{array}$ & $\begin{array}{l}\text { Terminal: Greater than } 4 \text { in. }(10 \mathrm{~cm}) \\
\text { Lateral: } 2 \text { in. }(5 \mathrm{~cm}) \text { to greater than } \\
4 \text { in. }(10 \mathrm{~cm})\end{array}$ & $\begin{array}{l}\text { Terminal: Greater than } 4 \text { in. } \\
(10 \mathrm{~cm}) \\
\text { Lateral: Less than } 2 \text { in. }(5 \mathrm{~cm})\end{array}$ \\
\hline Tree recruitment & Active & Active & Limited to absent \\
\hline Potential berry production & Low & Moderate to high & Low to near absent \\
\hline $\begin{array}{l}\text { Leader growth of } \\
\text { understory trees, in/yr } \\
(\mathrm{cm} / \mathrm{yr})\end{array}$ & $\begin{array}{l}\text { Terminal: Greater than } 4 \text { in. }(10 \mathrm{~cm}) \\
\text { Lateral: Greater than } 3 \text { in. }(8 \mathrm{~cm})\end{array}$ & $\begin{array}{l}\text { Terminal: } 2 \text { in. }(5 \mathrm{~cm}) \text { to greater } \\
\text { than } 4 \text { in. }(10 \mathrm{~cm}) \\
\text { Lateral: Less than } 1 \text { in. }(2 \mathrm{~cm}) \text { to } \\
\text { greater than } 3 \text { in. }(8 \mathrm{~cm})\end{array}$ & $\begin{array}{l}\text { Terminal: Less than } 2 \text { in. }(5 \mathrm{~cm}) \\
\text { Lateral: Less than } 1 \text { in. }(2 \mathrm{~cm})\end{array}$ \\
\hline
\end{tabular}


Table 6. Examples of perennial forbs and their tolerance to fire based on growth form.

[Modified from Miller and others, 2014]

\begin{tabular}{|c|c|}
\hline $\begin{array}{l}\text { Tolerant } \\
\text { (damage none to slight) } \\
\text { Buds below ground }\end{array}$ & $\begin{array}{l}\text { Intolerant } \\
\text { (damage moderate to severe) } \\
\text { Buds above ground }\end{array}$ \\
\hline $\begin{array}{l}\text { common yarrow } \\
{\text { (Achillea millefolium })^{1}}\end{array}$ & $\begin{array}{l}\text { pussytoes } \\
(\text { Antennaria sp. })^{1}\end{array}$ \\
\hline $\begin{array}{l}\text { agoseris } \\
\text { (Agoseris sp.) }^{1}\end{array}$ & $\begin{array}{l}\text { sandwort } \\
\text { (Arenaria sp.) }\end{array}$ \\
\hline $\begin{array}{l}\text { onion } \\
\text { (Allium sp.) }\end{array}$ & 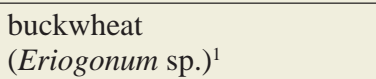 \\
\hline $\begin{array}{l}\text { asters } \\
(\text { Aster sp. })^{1}\end{array}$ & $\begin{array}{l}\text { spiny phlox } \\
\text { (Phlox hoodii) }\end{array}$ \\
\hline 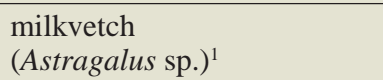 & \\
\hline $\begin{array}{l}\text { arrowleaf balsamroot } \\
\text { (Balsamorhiza sagittata) }\end{array}$ & \\
\hline $\begin{array}{l}\text { mariposa lily } \\
\text { (Calochortus sp.) }\end{array}$ & \\
\hline $\begin{array}{l}\text { hawksbeard } \\
{\text { (Crepis sp. })^{1}}^{\text {Crepis }}\end{array}$ & \\
\hline 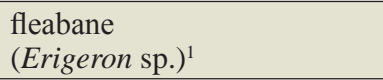 & \\
\hline $\begin{array}{l}\text { sticky purple geranium } \\
\text { (Geranium viscosissimum) }\end{array}$ & \\
\hline $\begin{array}{l}\text { old man's whiskers } \\
\text { (Geum triflorum) }\end{array}$ & \\
\hline $\begin{array}{l}\text { desert parsley } \\
(\text { Lomatium sp. })^{1}\end{array}$ & \\
\hline $\begin{array}{l}\text { lupine } \\
\text { (Lupinus sp.) }\end{array}$ & \\
\hline $\begin{array}{l}\text { bluebells } \\
\text { (Mertensia sp.) }\end{array}$ & \\
\hline $\begin{array}{l}\text { wooly groundsel } \\
\text { (Packera cana) }\end{array}$ & \\
\hline $\begin{array}{l}\text { beard tongue } \\
\text { (Penstemon sp.) }\end{array}$ & \\
\hline $\begin{array}{l}\text { longleaf phlox } \\
(\text { Phlox longifolia })^{1}\end{array}$ & \\
\hline $\begin{array}{l}\text { lambstongue ragwort } \\
\text { (Senicio integerrimus) }\end{array}$ & \\
\hline $\begin{array}{l}\text { largehead clover } \\
\text { (Trifolium macrocephalum) }^{1}\end{array}$ & \\
\hline $\begin{array}{l}\text { mule’s ear } \\
\text { (Wyethia amplexicaulis) }\end{array}$ & \\
\hline $\begin{array}{l}\text { death camas } \\
\text { (Zigadenus sp.) }\end{array}$ & \\
\hline
\end{tabular}

${ }^{1}$ Indicates known greater sage-grouse food.
- If grasses are mostly located under trees, the heat from the burning tree may kill those grasses leaving few grasses to survive and recover after the fire.

- Are invasive annual grasses part of the current vegetation community? If so, they will probably increase after a fire, especially on sites with soil temperature/moisture regimes on the warmer and drier ecological sites that can support trees. The exception is when adequate perennial grasses are present to compete with and eventually dominate invasive annuals.

- What are the impacts of fire on the habitat of animal species of concern (for example, sage-grouse)?

- Is this site potential sage-grouse habitat for nesting, brood rearing, or winter survival? Fire will likely remove sagebrush for decades making the site poor habitat for sage-grouse and potentially insufficient to sustain sage-grouse populations until sagebrush can return. Mechanical tree removal techniques might be better choices when compared with prescribed fire, especially if sagebrush still exist.

- When removing trees to achieve habitat for sage-grouse the physical structure of the surrounding vicinity may influence sage-grouse use.

- How large is the treatment area and is it adjacent to existing habitat? Connecting the restoration area to existing sage-grouse habitat has a high likelihood of creating usable new habitat.

- Does the surrounding area have trees or artificial structures that predators might use as perches while searching for sage-grouse? If so, this may not become usable habitat for sage-grouse even if it contains the correct plant species. 
Table 7. Examples of woody plants and their tolerance to fire.

[From Miller and others, 2014. Sprouting ability is indicated as (S) for sprouting, (NS) for non-sprouting, and (VS) for variable sprouting results]

\begin{tabular}{|c|c|c|}
\hline Tolerant & Moderately tolerant & Intolerant \\
\hline $\begin{array}{l}\text { Saskatoon serviceberry } \\
\text { (Amelanchier alnifolia) (S) }\end{array}$ & $\begin{array}{l}\text { threetip sagebrush } \\
\text { (Artemisia tripartita) (VS) }\end{array}$ & $\begin{array}{l}\text { little sagebrush } \\
\text { (Artemisia arbuscula) (NS) }\end{array}$ \\
\hline $\begin{array}{l}\text { silver sagebrush } \\
(\text { Artemisia cana })(\mathrm{S})\end{array}$ & $\begin{array}{l}\text { rubber rabbitbrush } \\
(\text { Ericameria nauseosa) (S) }\end{array}$ & $\begin{array}{l}\text { black sagebrush } \\
\text { (Artemisia nova) (NS) }\end{array}$ \\
\hline $\begin{array}{l}\text { Torrey’s saltbush } \\
\text { (Atriplex torreyi) (S) }\end{array}$ & $\begin{array}{l}\text { pines } \\
\text { (Pinus sp.) (NS) intolerant of crown fire }\end{array}$ & $\begin{array}{l}\text { big sagebrush } \\
\text { (Artemisia tridentata) (NS) }\end{array}$ \\
\hline $\begin{array}{l}\text { Gardner's saltbush } \\
\text { (Atriplex gardneri) (S) }\end{array}$ & $\begin{array}{l}\text { junipers } \\
\text { (Juniperus sp.) (NS) intolerant of crown fire }\end{array}$ & $\begin{array}{l}\text { fourwing saltbush } \\
\text { (Atriplex canescens) (VS) }\end{array}$ \\
\hline $\begin{array}{l}\text { snowbrush ceanothus } \\
\text { (Ceanothus velutinus) (S) }\end{array}$ & & $\begin{array}{l}\text { shadscale saltbush } \\
\text { (Atriplex confertifolia) (NS) }\end{array}$ \\
\hline $\begin{array}{l}\text { yellow rabbitbrush } \\
\text { (Chrysothamnus viscidiflorus) (S) }\end{array}$ & & $\begin{array}{l}\text { curl-leaf mountain mahogany } \\
\text { (Cercocarpus ledifolius) (VS) }\end{array}$ \\
\hline $\begin{array}{l}\text { Nevada jointfir } \\
\text { (Ephedra nevadensis) (S) }\end{array}$ & & $\begin{array}{l}\text { spiny hopsage } \\
\text { (Grayia spinosa) (VS) }\end{array}$ \\
\hline $\begin{array}{l}\text { quaking aspen } \\
\text { (Populus tremuloides) (S) }\end{array}$ & & $\begin{array}{l}\text { broom snakeweed } \\
\text { (Gutierrezia sarothrae) (VS) }\end{array}$ \\
\hline $\begin{array}{l}\text { Stansbury cliffrose } \\
\text { (Purshia stansburiana) (S) }\end{array}$ & & $\begin{array}{l}\text { bud sagebrush } \\
\text { (Picrothamnus desertorum) (NS) }\end{array}$ \\
\hline $\begin{array}{l}\text { desert bitterbrush } \\
\text { (Purshia glandulosa) (S) }\end{array}$ & & $\begin{array}{l}\text { Mexican cliffrose } \\
\text { (Purshia mexicana) (VS) }\end{array}$ \\
\hline $\begin{array}{l}\text { greasewood } \\
\text { (Sarcobatus vermiculatus) (S) }\end{array}$ & & $\begin{array}{l}\text { antelope bitterbrush } \\
\text { (Purshia tridentata) (VS) }\end{array}$ \\
\hline \multicolumn{3}{|l|}{$\begin{array}{l}\text { currant and gooseberry } \\
\text { (Ribes sp.) (S) }\end{array}$} \\
\hline \multicolumn{3}{|l|}{$\begin{array}{l}\text { Wood's rose } \\
(\text { Rosa woodsii) (S) }\end{array}$} \\
\hline \multicolumn{3}{|l|}{$\begin{array}{l}\text { mountain snowberry } \\
\text { (Symphoricarpos oreophilus) (S) }\end{array}$} \\
\hline $\begin{array}{l}\text { horsebrush } \\
\text { (Tetradymia sp.) (S) }\end{array}$ & & \\
\hline
\end{tabular}




\section{Step 4. Determine Land Use and Disturbance History}

Understanding the history of disturbance and previous use and/or management is important for recognizing the role these factors may have played in determining current conditions and how these disturbances may have influence the current plant community and soils of the site.

- What types of past or current land uses or disturbances have impacted or are impacting the restoration area?

Examples include but are not limited to:

$\circ$ Wildfire frequency, time since fire, and fire severity and intensity.

These fire regime characteristics may assist in understanding the plant community phases or even community states within S\&T models. The more frequently an area has burned, especially in the warm and dry sites, the more likely invasive annual grasses may dominate a site and sagebrush will be missing from the site.

- Roads, trails, campsites, pipelines, well pads, power lines, wind towers, past cultivation, or water impoundments and troughs for livestock.

These disturbances can create soil compaction, influence water infiltration, and become avenues for invasive species entry or spread. In addition, past plowing, pipeline trenches, or soil scraping, storage, and recontouring (as done by surface mining and energy development) can incorporate low soil horizons into surfaces and change soil textures or chemistry by mixing soil horizons. Changes in soil compaction, texture and chemistry may modify the plant species capable of establishing and growing at the site and may require soil modifications to alleviate these influences.

- Mining activities that removed vegetation or disturbed/ changed soils.

Surface mine reclamation requires top soil be stockpiled and revegetation of the disturbed lands, but other types of mining or abandoned mines may not have similar requirements.

o Wild horse or burro use of the restoration areas.

Are current numbers of animals and their level of use compatible with achieving restoration objectives? If not, is it possible to, at least temporarily, reduce numbers of animals?
○ Livestock use of the restoration area.

Is current grazing management (for example, animal type, stocking levels, and season of use) compatible with achieving sustainable restoration objectives? If not, can use be halted or changed, at least temporarily (passive restoration method)?

- Are there indicators that disturbances have potentially changed the soil or site stability, hydrologic functioning, or the biotic integrity of the site?

The current plant community was compared against the plant community phases for the ecological site, but there are additional indicators that could be examined to determine if the additional conditions might influence restoration success. Interpreting Indicators of Rangeland Health (Pellant and others, 2005) can be used for this determination. The ecological site description for the current location has a reference sheet that describes the expected levels for 17 indicators used to rate the three attributes of land health: Soil and Site Stability, Hydrologic Function, and Biotic Integrity. If any of these attributes are rated as a moderate or greater departure from the reference description, then the rating may indicate a set of soil, hydrological, or biological indicators that may impact vegetation recovery using passive restoration approaches. These locations may need active restoration or rehabilitation approaches to improve the ecological status of the site.

- Soil and Site Stability is the capacity of an area to limit redistribution and loss of soil resources including nutrients and organic matter by wind and water.

Indicators of soil and site stability include: rills; water-flow patterns; pedestals and terracettes; gullies; wind-scoured, blowouts and deposition areas; litter movement; soil surface resistance to erosion; soil surface loss and degradation; and compaction layer.

- Hydrologic Function is the capacity of an area to capture, store, and safely release water from rainfall, run-on, and snowmelt (where relevant); to resist a reduction in this capacity, and to recover this capacity when a reduction does occur.

Indicators of hydrologic function include: rills; water-flow patterns; pedestals and terracettes; gullies; soil surface resistance to erosion; soil surface loss and degradation; plant community composition and distribution relative to infiltration; and compaction layer. 
- Biotic Integrity is the capacity of the biotic community to support ecological processes within the normal range of variability expected for the site, to resist a loss in the capacity to support these processes, and to recover this capacity when losses do occur.

Indicators of biotic integrity include: soil surface resistance to erosion; soil surface loss and degradation; compaction layer and functional and structural groups including biological soil crusts; plant mortality or presence of dead plant parts; litter amount; annual production; invasive plants; and reproductive capability of perennial plants.

- Could eliminating or reducing grazing animals or changing grazing season for 1 or more years before treatment improve the effectiveness of the treatment?

Temporary elimination or reduction of animal numbers or a change in season of use by animals may improve effectiveness of some treatments because perennial plants can have time to grow and become more robust to subsequent grazing effects. For example, eliminating grazing animals for 1 or 2 years before a prescribed fire may produce more fine fuels to carry the fire across the treatment area. Another example is changing season of use by grazing animals to improve seed production of desirable plants, but this should be done with caution if undesirable plants also occur because they too may respond with more seeds and increase along with the native desired plants.

\section{Step 5. Pre- and Post-Treatment Weather and Its Influence on Success}

Weather during years before and after a revegetation treatment have a strong influence on the effectiveness of that treatment (Hardegree and others, 2012). Pretreatment weather may impact fuel loads and seed banks for invasive plants that may compete with desired plants in a restoration treatment. Above average precipitation during the growing season, especially during the winter and spring, may increase annual grass growth (fuels), seed production, and associated seed banks. If these situations existed before the treatment then prepare to potentially treat annual grasses either before or during the year of treatment. For 2-3 years after treatments, precipitation will influence seed germination, seedling establishment, growth, and survival. Although these factors may not be easy to control, anticipation of conditions by way of long-range weather forecasts may be useful for scheduling (or re-scheduling) actions to maximize effectiveness (Hardegree and others, 2016).
Long-range weather forecasts (seasonal; less than 1 year) are dependent on past, current, and future predicted ocean current patterns in the Pacific and Atlantic Oceans in association with past and current weather. A variety of models use climate and weather data to project future seasonal predictions and the Climate Prediction Center with the National Oceanic and Atmospheric Administration use an ensemble of these models to predict seasonal weather across the United States (http://www.cpc.ncep.noaa.gov/ products/predictions/90day/, accessed March 28, 2016). This information may help inform decisions on moving forward with revegetation projects for regions of interest, whereas climate model scenarios (combinations of atmospheric and ocean general circulation models with emission scenarios) may be used to provide insights into long-term trends and future site potential.

\section{Step 6. Potential Restoration Treatment Types and Associated Impacts}

Restoration is placed in two types based on the degree of immediate change necessary to achieve restoration. Passive restoration involves changing current management of the area to allow natural processes (for example, plant succession) to move plant communities to a desired composition and structure without direct investment in treatments. Generally, all plant species required to achieve the restoration objective already occur at the restoration location, but not in the desired composition for passive restoration to be effective. Although the change in management may occur quickly, processes that bring about plant compositional changes may require considerable time and appropriate weather conditions to achieve the restoration objective, thus monitoring for several years may be necessary to determine if objectives are achieved. Active restoration may be necessary if desired species have been eliminated from sites or if the time necessary for recovery is longer than desired to meet objectives through passive restoration. In these cases, investments in site preparation and seeding are used to "jumpstart” successional processes.

\section{- Passive Restoration Options.}

These options rely on changing current management to allow the plant community to recover through successional processes. Recovery, however, often depends on the site productivity, which depends on soil temperature, moisture, nutrients, texture, and depth. In sagebrush steppe ecosystems, sites with cool to cold soil temperature regimes and with moist to humid soil moisture regimes tend to be more resilient to disturbances and more resistant to invasive annual grass establishment and spread. Thus, cooler and moister sites would be expected to respond more positively to changes in management of disturbances (passive restoration) than warmer and drier locations (table 3). Types of passive restoration include, but are not limited to: 


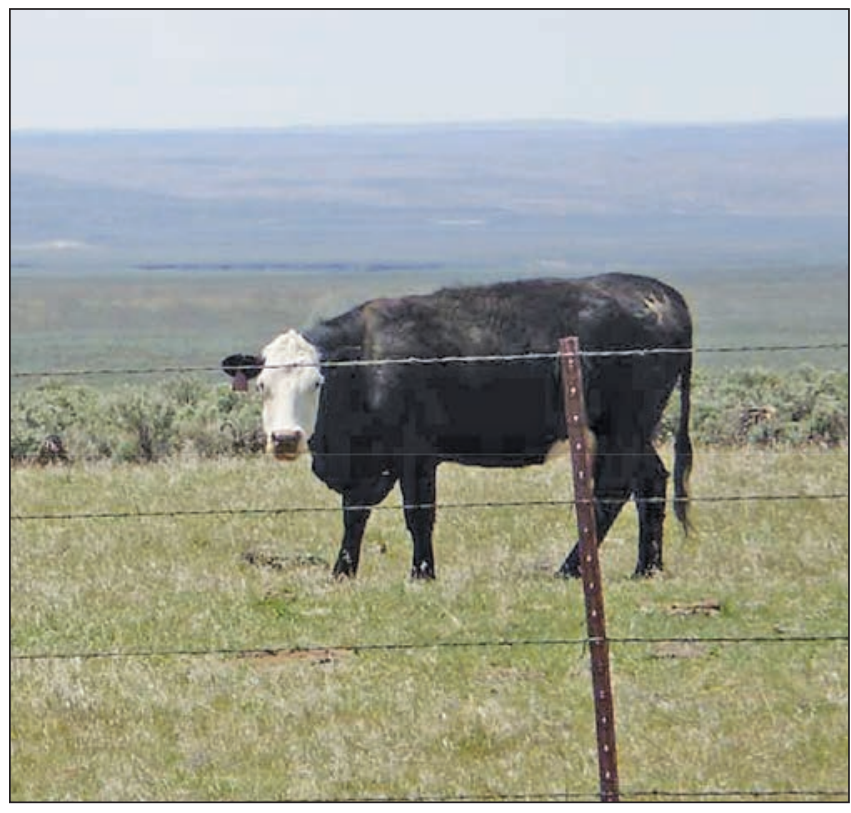

Targeted cattle grazing on cheatgrass the Bureau of Land Management Jarbidge Field Office near Twin Falls, Idaho.

\section{$\circ$ Livestock grazing.}

Herbivory and trampling by large grazing animals can be manipulated two ways: (1) changing season of use or (2) changing their level of use (through adjusting stocking rates, herding, or adjusting access to water).

- Within the western part of the sagebrush steppe there is general agreement that most of the dominant native perennial grasses are less tolerant of repeated annual grazing between the early boot stage and seed dispersal.

- In the eastern portion where warm-season $\left(\mathrm{C}_{4}\right.$, see Part 1 of the handbook on restoration of sagebrush steppe ecosystems [Pyke, Chambers, and others, 2015] for explanations of warm- and cool-season grasses) grasses codominate with cool-season $\left(\mathrm{C}_{3}\right)$ grasses, some of the cool-season bunch grasses have similar low grazing tolerance to perennial grasses of the western region and may lead to shifts in dominance to warm-season grasses with repeated late spring grazing.

- Shifts to grazing during the early growing season or the dormant season may benefit plant recovery through enhanced reproduction and greater likelihood for seedling establishment and survival. However, in sage-grouse nesting and brood-rearing habitat this grazing would need to maintain grass heights to provide adequate cover.

- Reductions in stocking levels may achieve similar results, provided fewer plants are grazed annually.
○ Feral horses and burros.

These animals may cause similar impacts as livestock, but management options are restricted to reductions in the numbers of animals. Lands around water sources are particularly vulnerable to overuse because horses will return to these locations throughout the year.

○ Road and trail access to restoration areas.

Roads and trails may be seasonally restricted, or sites may have limited use or completely closed to reduce the potential for invasive seed transport into recovery areas. Cleaning vehicles moving in and out of areas of concern may assist recovery by controlling the introduction or re-introduction of invasive species (Fleming, 2005).

\section{- Active Restoration Options.}

Active restoration is required when management changes and natural successional processes are inadequate to meet vegetation objectives. Active restoration will generally include revegetation through seeding or planting species or through controlling undesirable species by mechanical, chemical, or prescribed fire treatments. When selecting active restoration options, it is important to consider site characteristics that might be impacted by the choice of treatments; for example, treatments that increase the potential for soil erosion or compaction, or characteristics that might impact the effectiveness or safety of certain equipment, such as steep slopes or stony soils. Treatments often fall into two categories, surface or aerial applications. Surface applications breakdown further into powered or manual techniques. Powered vehicles (fuelor animal-powered) operate with wheel or sometimes continuous track vehicles. When surface equipment or labor is incapable, impractical, or unsafe to conduct, aerial techniques may provide an alternative.

- Surface applications.

Rangeland drills are generally the preferred method of seeding wildland plants that germinate and establish best with seed burial. However, success seems to depend on mean annual precipitation (30-year mean), with perennial grasses increasing when mean annual precipitation is equal to or greater than 13 in. $(33 \mathrm{~cm})$ (Knutson and others, 2014). Minimum-till rangeland drills were recently introduced that create less soil disturbance and may reduce invasive species along drill rows because they do not leave furrows that may capture invasive species seeds (Ott and others, 2016). Regardless of drill type, species with smaller seeds may require surface sowing which is often accomplished through placing the seed on the soil surface followed by a technique to insure good seed-to-soil contact (for example, the use of a cultipacker or press wheel). 
The ability to use seed drills and many plant control techniques that mechanically or chemically reduce undesirable species is restricted by steep slopes (greater than 30 percent) and stoniness of soil (greater than 15 percent cover). For example, mower blades can be damaged by stones and contact with stones may create sparks and ignite fires. Flail shredders with flexible hammers may be used on stony soils, but the risk of fire may still exist.

$\circ$ Aerial applications.

Herbicides, pesticides, soil amendments (for example, mulch, and fertilizer), fire propellants, as well as seeds may be applied using helicopters or fixed-wing aircraft. Aerial seeding has often resulted in mixed success because seeds are mixed together and often left on the surface, which puts them at risk for being eaten, blown, or washed from where they were intended to germinate and grow. Without techniques to cover seeds or place them in better contact with the soil, aerial applications in the Great Basin are most effective when done on areas that receive more than 10.6 in. $(27 \mathrm{~cm})$ mean annual precipitation, but only when seeding introduced perennial forage grasses, not native grasses (Knutson and others, 2014). Success generally improves if aerial applications are followed by a technique to cover seeds with soil or plant litter, which may include spreading mulch over the surface to protect the seed from water movement. Harrows or anchor chains pulled by tractors may provide an effective technique to cover aeriallyapplied seed with soil, provided slopes are less than 50 percent (sometimes slopes as much as 65 percent) to prevent equipment from rolling over. Steep slopes can affect application of proper herbicide rates because of the greater surface area on a slope relative to a flat. Helicopters can compensate by flying more parallel to the slope than fixed-wing aircraft, but limitations still occur.

- Soil erosion potential and treatments.

Erosion by water or wind is a major concern with any restoration project, especially if it is necessary to remove vegetation or disturb soils to implement the project (Web Soil Survey, http://websoilsurvey.nrcs. usda.gov/app/HomePage.htm, accessed October 20, 2016) provides geospatial soil maps and interpretations associated with each soil map unit including water and wind erosion hazard.

- Water erosion. Models of the potential for water erosion of soil are available to aid in determining risks. The Erosion Risk Management Tool (ERMiT, http://forest.moscowfsl.wsu.edu/cgi-bin/fswepp/ermit/ ermit.pl, accessed June 14, 2016) is a web-based tool that uses a model for predicting the probability of soil

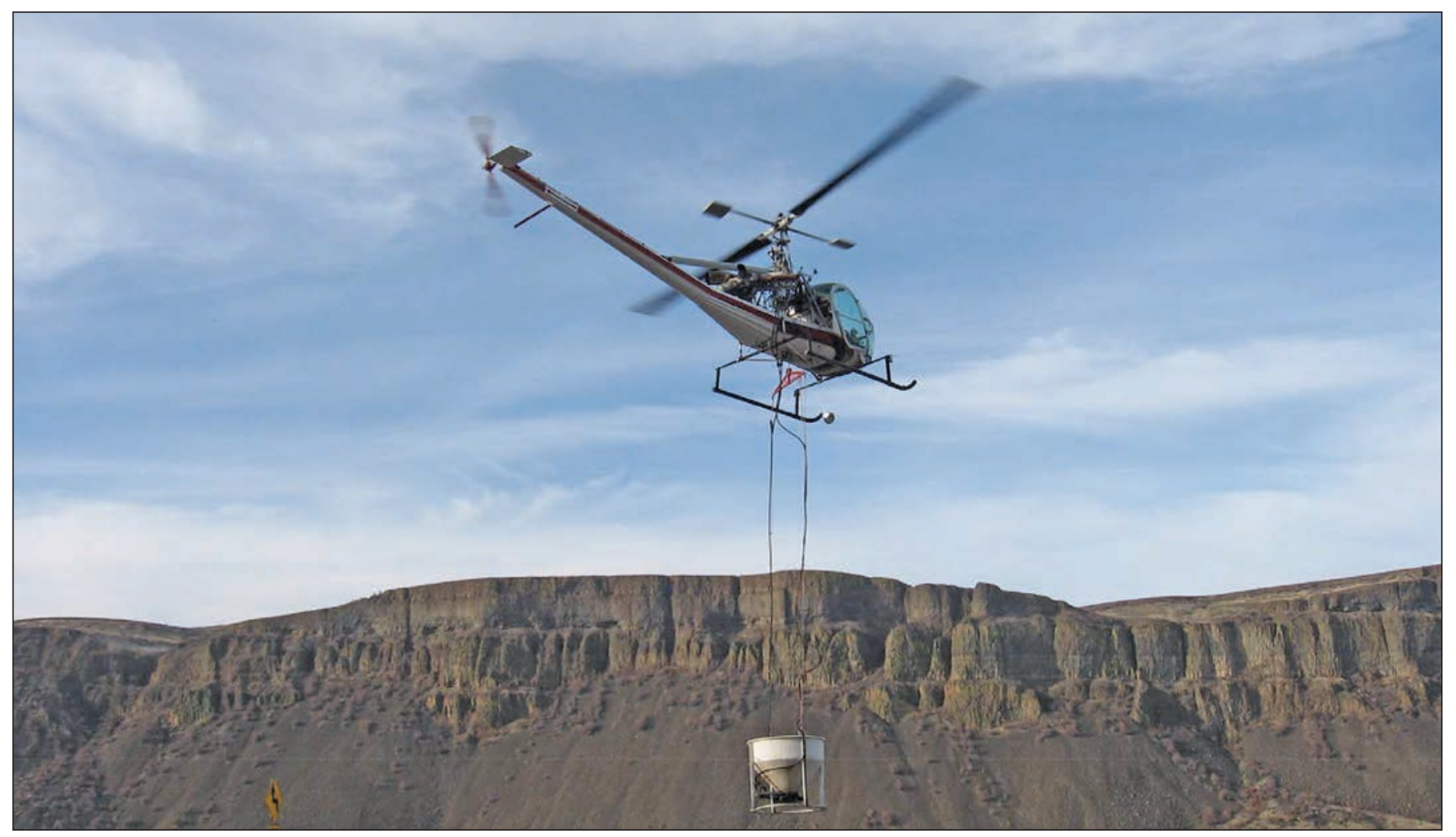

Helicopter lifting a bucket for tebuthiuron herbicide to thin woody plants in Moses Coulee, Washington. (Photograph by Scott Schaff, U.S. Geological Survey Forest and Rangeland Ecosystem Science Center, November 24, 2008.) 
erosion from rainfall. It can be used in rangelands and forested lands. The Rangeland Hydrology and Erosion Model (RHEM) model (http://dss.tucson.ars. ag.gov/rhem/, accessed July 27, 2016) is a rangelandspecific model focused on water erosion. Information on erosion and mass movement of soil can aid managers in deciding whether soil disturbance or if lack of perennial vegetation creates a greater risk of water-caused soil movement or loss. In general, fine soils and steep slopes have an increased risk of water erosion. Arid and semi-arid regions often experience seasonal or episodic precipitation events that may cause rapid erosion. In these regions, planning for erosion may be important for long-term success.

- Wind erosion. In general, fine textured soils on sandy sites are often prone to wind erosion. Soil descriptions will provide a guide regarding erosion risks on these sites. Caution should be used in conducting actions that cause soil disturbances on highly erodible sites. To our knowledge, no simple models are readily available for predicting wind erosion on sites.

- Revegetation on erodible soils. Revegetation on erodible soils requires fast-growing plants in seed mixtures for quickly stabilizing and protecting soils in the short term. Generally, revegetation to protect soils from erosion can take more than 1 year and often does not provide adequate protection if high rainfall occurs in the first few years after a fire (Robichaud and others, 2000; Sankey and others, 2012).

- Use of sterile annual grasses. The use of fast growing sterile annual grasses (for example, wheat) to stabilize soils and decrease annual grass establishment may be effective if used as part of a two-step process in which the sterile annuals are seeded in the first year followed by revegetation in the second year (Jones and others, 2015). Competition between the sterile annual grasses and invasive annual grasses tends to reduce the abundance of invasive plants. However, in some locations these sterile annuals may compete with desirable perennial seeded species, thus negatively impacting the long-term objective of achieving perennial plant cover to protect soils (Beyers, 2004). This is especially true in more arid areas where fast growing annual cover crops can impact perennial plant establishment. Balancing the potential dominance of annual colonizing species with the growth and expansion of desirable perennial species is one of the challenges when using controlled disturbance in habitat management.
- Use of surface mulch. Surface mulch also may capture and store moisture while providing some soil protection from wind and water-induced soil erosion if rainfall intensity remains low, but will likely be less effective with increasing wind or rain intensity. Finer materials will improve soil organic matter and more quickly contribute to soil stability than coarser materials that decompose slowly in dry environments. Straw wattles for soil erosion control on steep slopes have been shown to have minimal success relative to surface mulch techniques and are rarely used (Robichaud and others, 2010). Weedfree mulch reduces the likelihood of introducing invasive plants with the mulch. Rice straw, since it is grown in wetlands, is a good alternative to meadow hay from upland communities because invasive plants from rice fields will not likely survive in sagebrush ecosystems.

○ Steep slopes and treatments.

Slopes greater than 30 percent will limit the use of tractors, because of the risk of equipment rolling over when it is traversing perpendicular to the slope, for some mechanical vegetation controls and for planting seeds with seed drills; a practice used to reduce the risk of drill furrows concentrating water and accelerating rill erosion.

○ Surface stones and treatments.

Sites with surface stones greater than 15 percent will often have soil map unit component names using "stony" (rocks with diameters greater than 10 in. or $25 \mathrm{~cm}$ ). Stones of this size and coverage can restrict the use of some types of surface equipment (for example, spray equipment, seed drills, harrows, or chains). Aerial methods, if available, may be necessary.

- Soil firmness in upper horizons $(0-6$ in. $[0-15 \mathrm{~cm}])$ and treatments.

Loose unconsolidated soil particles are prone to soil erosion and do not provide good soil-to-seed contact necessary for optimal germination. Soil stability tests (Herrick and others, 2009) conducted at the surface and subsurface (approximately 1 in. [ $2.5 \mathrm{~cm}]$ deep) provide soil aggregate stability values that help estimate relative soil firmness. Sites with aggregate stability values of 1 or 2 have relative little soil firmness (potentially loose when disturbed) in comparison with soils with aggregate stability values of 5 and 6 (generally firm when disturbed). Use caution when drill seeding on loose soils because they are prone to wind erosion, especially fine textures, because seed drills may break thin physical or biological soil crusts that are currently holding soils in place. Disturbance of this crust may initiate wind erosion by saltation. If the seedbed has loose soils, 
it may require some soil firming during seeding (for example using packer wheels or cultipackers). For example, sagebrush is a species that establishes better on a firm seedbed. In addition, seed drills may require depth bands or hydraulic seeding depth control to place seeds at the proper depth to promote good germination.

○ Subsurface soil compaction and treatments.

Areas of high use (for example, trails, and permanent water locations for animals, roads, or well pads) may have a strong compaction layer (soil layer with less pore space usually within $2-3 \mathrm{in}$. [5.0-7.5 cm]) of the soil surface) that can restrict water movement into soils, decrease water holding capacity of the soil, and increase the potential for surface runoff of water. If soil compaction exists, consider whether plowing or ripping the soil might help in breaking the compacted layer and provide for seedling root penetration and establishment. Additional soil preparation (disk or harrow followed by cultipacker) may be necessary to reduce soil clods for acceptable seed placement for germination and establishment. However, caution should also be exercised as soil disturbance may require additional recovery time, especially in warm and dry areas, because most biotic soil processes are affected by temperature and moisture.

- Plant control and prescribed fire.

Generally, when active restoration is necessary, sites are fully occupied by plants whose species are not desired or their dominance relationships are not at desired levels. In these cases, plant controls or manipulations can be implemented before seeding occurs. If you consider that fire might provide desired results, then work with a certified fire management professional or an agency fire specialist to achieve objectives. Generally, the goal of prescribed fire is to modify species composition by reducing undesirable, firesensitive species and favoring desirable fire-tolerant or fire-resistant species. In addition, prescribed fire may be used, at least temporarily, to eliminate woody plants and make it possible to use other equipment for plant control or seeding. After fire, some plants may increase while others decrease, causing changes in relative abundances of species over time. See Pyke and others (2010) and Miller and others (2013) for more details. For information on how specific plants respond to fire refer to the Fire Effects Information System (FEIS; http://www.feis-crs.org/feis/, accessed June 14, 2016). Miller and others (2014) also developed a scoresheet to evaluate the suitability of a site for prescribed fire that is useful for projects in the Great Basin and Columbia Plateau (appendix B).
- Prescribed fires in sagebrush communities with sage-grouse. If the restoration area is a sagebrush community that currently supports sage-grouse at some period of the sage-grouse life-cycle, then the use of fire as a management tool should be carefully evaluated because it can be more detrimental than beneficial to sage-grouse habitat, especially in the short term (20-40 years). Sage-grouse habitat generally contains big sagebrush and the time required to re-establish it means the extent of the fire may no longer support sage-grouse until big sagebrush returns to adequate size and density. In high elevation areas with mountain big sagebrush, the potential for recovery (resilience) is high and a shorter time may be required for the recovery of the plant community (high resilience) than in lower elevation sites that are warm and dry (low resilience). Prescribed fire may be a viable option in high resilience sites, especially to control conifer expansion. However, fire in some cases may be an excellent tool for manipulating species dominance as well as preparing sites for effective uses of other restoration techniques (for example, using fire to remove invasive species or litter layers to enhance the effectiveness of an herbicide treatment).

- Prescribed fires in non-sagebrush communities or in sagebrush communities without sage-grouse. Fire is generally used to reduce the dominance of woody plants such as piñon pine or juniper. Prescribed fires also may provide a temporary reduction (1-2 years) of annual plants such as cheatgrass, because given the right conditions, fires can consume seeds in the litter and the soil seed bank thereby reducing the population of cheatgrass plants for the next year. The amount of reduction is dependent the fire conditions. When cheatgrass dominates an area, the greatest reductions in cheatgrass populations are achieved when fire intensity (energy released) is high and fire duration is long, allowing the fire to consume standing dead plant material and litter while transferring sufficient heat into the soil to reach lethal temperatures for the seeds. Work with an experienced fire management officer who can devise the appropriate prescription to kill the maximum number of seeds in seed banks while maintaining safe burning conditions to control the fire.

- Fire characteristics that influence plant responses. There are characteristics of each fire that may positively or negatively impact plants and their survival. The major characteristics that may be controlled in a prescribed fire include fire intensity, duration, type, extent, and patchiness. Intensity refers to the heat energy generated by a fire. 
Fire intensity is strongly associated with the amount of fine fuel, namely leaves and herbaceous plants; however, woody fuels with flammable volatile compounds in their leaves or stems may generate more heat than herbaceous fuels. Burning shrubs and trees often create local severe effects due to accumulation of fine fuels and extended burn duration caused by woody fuels, and this behavior can kill all plants and seeds under their canopies.

Fire duration is the time which a fire burns at a given location. Woody materials burn longer, with larger stems and branches potentially burning longer than smaller ones. Tree and shrub roots often facilitate entry of fire into the soil profile, increasing the subterranean heat pulse locally. The combination of heat and duration determine the depth of the heat pulse in the soil, which dictates whether seeds survive in the soil seed bank even though they may not be consumed by the fire. The cumulative effect, when the heat pulse causes mortality, is referred to as the lethal temperature. Lethal temperatures can be lower when fire duration is longer and when sufficient soil moisture exists to facilitate transfer of heat into the soil. Back fires are often used in prescribed fire management to achieve these conditions because they tend to burn with longer durations than other fire types.

Fire type relates to the direction and the position of the fire front relative to the wind direction or the soil surface. Head fires burn in the same direction of the wind (burn with the wind) and tend to burn with high intensity but short durations. These can result in lower plant and seed mortality relative to back fires that burn against the direction of the wind, creating lower flame lengths and intensity but longer durations.

Fire extent (size) and patchiness are indications of the continuity of the fuels that burn and the current weather and fuel moisture conditions. Hot, dry conditions with low plant fuel moisture and high wind speeds will allow fires to ignite easily and spread quickly. Low air temperatures, high humidity, or low wind speed will slow fires and may make some plant material difficult to ignite. Thus, various combinations of fuel distribution, weather, and topography can yield fires that burn in patches. Patchy or fragmented fires create unburned vegetation islands within a larger burned area and create greater burn perimeter-to-area ratio than continuous fire across the same burned area. These patchy fires may allow for faster dispersal of seeds into burned sites while still providing the ecological benefits of a fire. Large fires

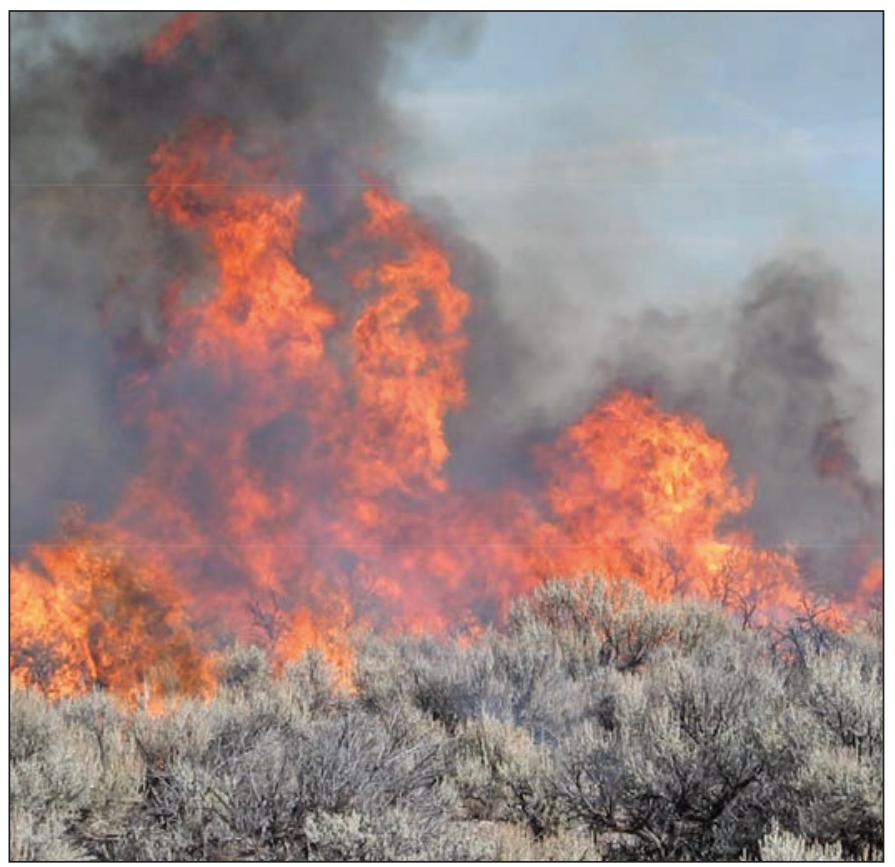

Experimental prescribed fire on sagebrush steppe plant community on the U.S. Fish and Wildlife Service, Hart Mountain National Antelope Refuge, Oregon. (Photograph by Scott Schaff, U.S. Geological Survey Forest and Rangeland Ecosystem Science Center, October 18, 2006.)

without unburned patches especially in warm and dry environments generally require the longest time to recover and may require seeding to reintroduce sagebrush more rapidly to these sites because seed banks of sagebrush are limited.

Steep slopes also will impact fire behavior and intensity. Habitat biologists and fire managers working together may examine fire options based safety requirements and vegetation objectives. If objectives for fire use are to control vegetation and remove seed banks, then slow moving, backing fires with longer durations may achieve these goals; however, limitations imposed by the need for safe weather conditions during prescribed fires may preclude use of effective backing fires in some ecosystems. Fires burning up slopes often spread rapidly with shorter duration thereby reducing the likelihood of achieving lethal temperatures in soil seed banks. Head fires are typically wind driven and more difficult to control due to rapid rate of spread and high intensity fire behavior; patchiness created by these fire fronts will usually be dictated by wind and topography, they are rarely used in managed fire situations. Regardless of the type of fire, fires will create more bare ground immediately after the fire, and steep slopes can contribute to soil erosion (previously explained), therefore caution should be used with prescribed fire on erodible soils. 
- Plant responses to fire. Pyke and others (2010) describe how the location of perennial buds and the presence of a seed bank relative to soil surface are important features that influence plant responses to fire.

Annual plants require an adequate seed bank in the soil to survive fires. To reduce annual plants with fire, the fire intensity must be sufficient to achieve lethal temperatures to kill nearly all seeds in the litter and at or buried slightly below the soil surface. When seeds of annual plants survive a fire, they are often able to incorporate the nutrients that become available after the fire quicker than perennial plants. For example, plant-available nitrogen and moisture often increase immediately after a fire and can persist for at least 1 year. Invasive annual grasses that germinate in the fall or winter and grow quickly are adapted to take advantage of this nutrient increase before many perennial plants have recovered. If these grasses are in the pre-fire community, they will likely have some seeds survive and those plants will respond to the increased levels of nitrogen with higher than normal seed production. Thus, fire alone in communities with dominant or co-dominant invasive annual grasses and with few woody plants may show an initial decline in annual grass dominance from fireinduced seed mortality, but those seeds that survive will produce plants that may recover quickly if fire is not combined with other plant control techniques and/or revegetation of perennial grasses. Because annual grasses are more likely to invade and dominate sites with warm-dry soil temperature and moisture regimes, and because these sites generally have poor restoration success, the use of fire in these locations as a control or a site preparation tool should be evaluated carefully before proceeding. On cool-moist sites where sagebrush and cheatgrass codominate, there is generally a 1-year window of opportunity for reseeding before cheatgrass increases and again dominates the site.

Perennial plants must rely on their bud placement and regrowth potential for surviving a fire.

Perennial plants with buds above the soil surface are vulnerable to fire-induced mortality, whereas those with buds below the soil surface may resprout after fires (tables 6 and 7). Note that some species and genotypes of bitterbrush (Purshia sp.) resprout while others do not, so this plant is site specific in its survival response to fire. Perennial grasses in the Intermountain West have buds at or slightly above the soil surface and vary in their susceptibility to fire depending on the amount of leaves near the crown of the plant where buds exist. Idaho fescue (Festuca idahoensis) tends to have more leaves packed near the plant crown and is generally more susceptible to fire-induced mortality than bluebunch wheatgrass. Many forbs resprout from root buds or below ground storage organs (for example, bulbs, corms, and tubers) and are highly resistant if they are present at the site.

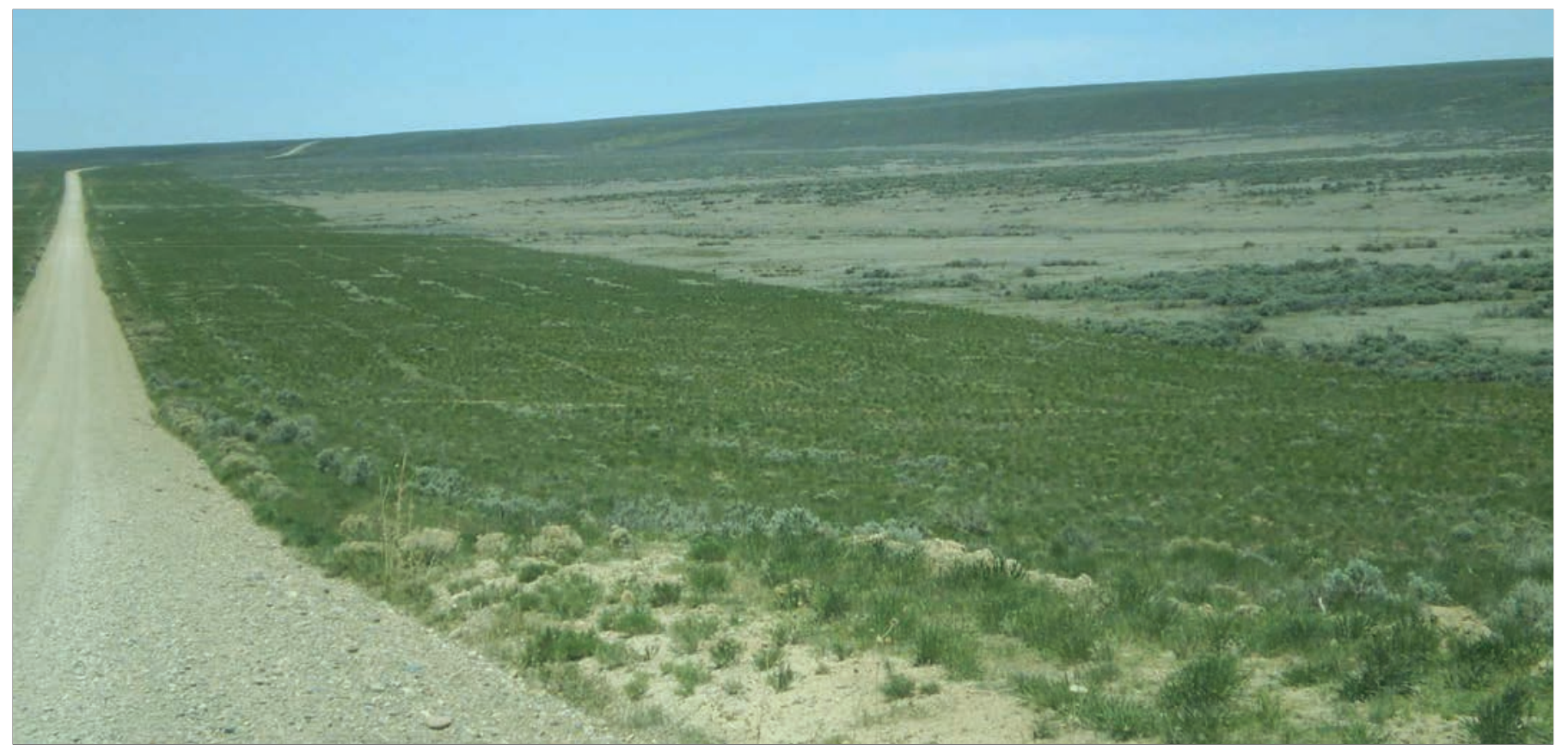

Greenstrip being installed in the Bureau of Land Management Jarbidge Field Office, to act slow fires and assist in controling fire extent, near Twin Falls, Idaho. 
- Prefire fuel assessment (from Miller and others, 2014). Tradeoffs exist between conditions necessary to carry a fire that will meet vegetation objectives and to provide a safe environment for implementing a prescribed fire. In addition, some federal agencies restrict the use of prescribed fire in sagebrush steppe unless a rationale for using fire over other alternatives are explained in the National Environmental Policy Act analysis because of the sage-grouse habitat concerns (Bureau of Land Management, 2015a, 2015b). The following are questions to ask to help determine if prescribed fire can safely meet vegetation objectives.

- How will abundance and structure of current vegetation, including invasive plants, influence fire severity (degree of loss or change in organic matter above, at and below the surface)?

- Are surface fuels adequate to carry a fire across a shrubland or woodland?

- If piñon or juniper occupies the site: (1) In what woodland phase (I, II, or III) is the stand (table 5)? Later woodland phases (II and especially III) have higher total fuel loads that require more extreme weather conditions to carry a fire caused by the lack of horizontal surface fuel continuity, (2) Are ladder fuels (primarily shrubs) sufficient to carry the fire into tree canopies, (3) Are tree fuels (tree size, distances between trees, and density of canopies) so great as to result in a high severity fire that may kill even tolerant desirable plants?

- What weather conditions are necessary to carry a fire and what severity of fire is likely?

- How will site characteristics (slope and aspect) affect fire severity?

- How do fuels influence the season of burning and when is it most appropriate (see Miller and others [2013] for effects in Great Basin, Columbia Plateau, and Snake River Plains)?

○ Plant control and mechanical treatments.

Generally mechanical techniques are used to reduce woody plant competition or to modify fuel distributions within a stand. Depending on the technique, mechanical treatments have a range of soil disturbances. Soil disturbance can have positive effects for seed-to-soil contact especially for broadcast seeds, but it also can have negative effects by increasing the amount of exposed mineral soil (bare ground), which may lead to other negative ecosystem responses such as soil erosion by wind or water. For equipment descriptions and their applications, access the Revegetation Equipment Catalog (http://reveg-catalog.tamu.edu/index.htm, accessed June 24, 2016).

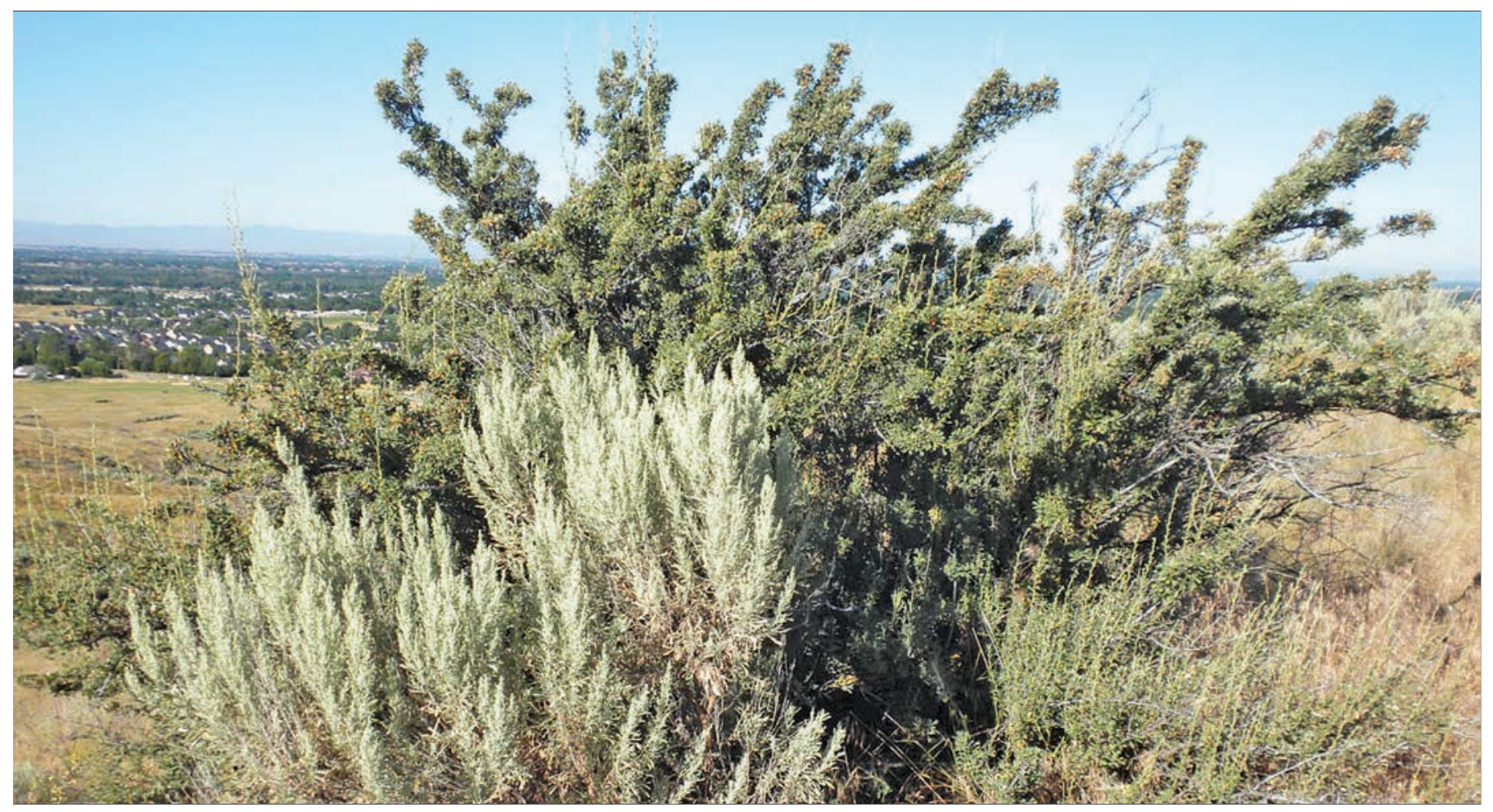

Sagebrush and bitterbrush near Boise, Idaho. 
- Pre-mechanical treatment assessment (from Miller and others, 2014). Weigh costs (money and nontarget plant impacts) against benefits of treatments. Questions to consider, related to potential costs or negative impacts, include: (1) Will it cause unacceptable soil compaction, (2) Will it create unacceptable amounts or distributions of bare ground, (3) Will it harm biological soil crusts? (4) Will it damage existing perennial grasses and forbs, (5) Will it provide a seed bed for seedling establishment? If so, are there invasive species in the area that may take advantage of the disturbance caused by this treatment, (6) Will the slope of the site contribute to rill or surface erosion or soil instability, and (7) Will changing the timing of the mechanical treatment influence the plant response positively or negatively?

The following mechanical treatments are listed in order of increasing severity for soil disturbance and impact on non-target species. In addition, take care in regarding the timing of these techniques when invasive species are present. Applications of mechanical treatments before the invasive plants flower and set seed is less detrimental than after seed set. However, use of these techniques in the spring may negatively impact wildlife. Consult with wildlife biologists to determine the best time for these types of treatments.

- Harvesting. This can range from humans felling trees to mechanical harvesters (for example, feller buncher) that cut at the base, limb, and stack trees for removal. Low impact wheels and treads on equipment, and minimal use of skidding (of large stems) can help to minimize impacts of tree harvest. Human felling of trees is generally less disturbing than mechanical equipment. This is the preferred technique for many managers when removing piñon and juniper in sagegrouse areas where sagebrush still exists. If trees are not removed, then jackpot burning or piling and burning are often used to remove the trees. Burning these trees often results in high intensity fires that sterilize soils of plants and nutrients for multiple years and may eventually become habitat for invasive annual grasses before they support native perennial plants.

- Mowers/flails/shredders/rotobeaters/chipping. This group of equipment is designed to cut, chop, or shred non-sprouting plant material above the deck height of the equipment. They can be set close to the soil to remove nearly all live vegetation, but with lower deck heights there is greater likelihood of soil disturbance, especially when using horizontal blades rotating around a vertical shaft. Undulations in the soil surface may exacerbate this problem. These tools do not work well in rocky soil if near surface application is the goal, because damage may occur. Stones striking mower blades can produce sparks that may ignite wildfires. Flail shredders with flexible hammers might be a better option than mowers under dry conditions.

- Pipe harrow or dixie harrow. This is a series of steel pipes with several triangular blades welded along the length and pulled lengthwise behind a tractor. It removes or thins brittle shrubs such as sagebrush while disturbing the soil. Pipes can be removed to thin fewer shrubs. Multiple passes remove more shrubs. This tool works well in rocky soil where mowers/ shredders may not be used for fear of damage.

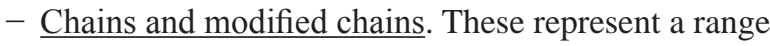
of large ship anchor chains, either alone or with a variety of modifications (for example, disks, railroad ties, and blades) connected to disturb the soil. The chain is pulled between two tractors while keeping it in a U- or J-shape, depending on the type of chain. Brittle shrubs and trees may be broken or up-rooted. Smaller woody plants may merely bend and not break, and thus escape removal. This is commonly used to remove large juniper and piñon trees in some parts of the region.

○ Plant control and chemical treatments (consult with a certified applicator).

Herbicides come in many varieties and impact plant growth in many ways. Some are selective, only affecting a specific plant life form or structure. Others are capable of killing all plants, but can act as selective herbicides if applied at the right season or at low application rates. Some herbicides require contact with actively growing plants at the time of application; others bind to soils, are actively taken up through roots, and may have residual impacts on plants that last for months or years. If herbicides are applied, label instructions for the specific herbicide should be precisely followed. Annual grasses are problematic in sagebrush ecosystems with a variety of herbicides that are listed for use in controlling them (table 8).

Several herbicides that are commonly used in sagebrush ecosystems for plant community manipulations are addressed briefly below.

- Glyphosate. This herbicide is non-selective and may kill or harm nearly all plants that are actively growing and are contacted by an adequate amount of the herbicide. As a contact herbicide, it kills plants by being absorbed through leaves and inhibiting production of certain amino acids and proteins necessary for plant growth. It has no residual activity and degrades quickly after it contacts soil. It will not 


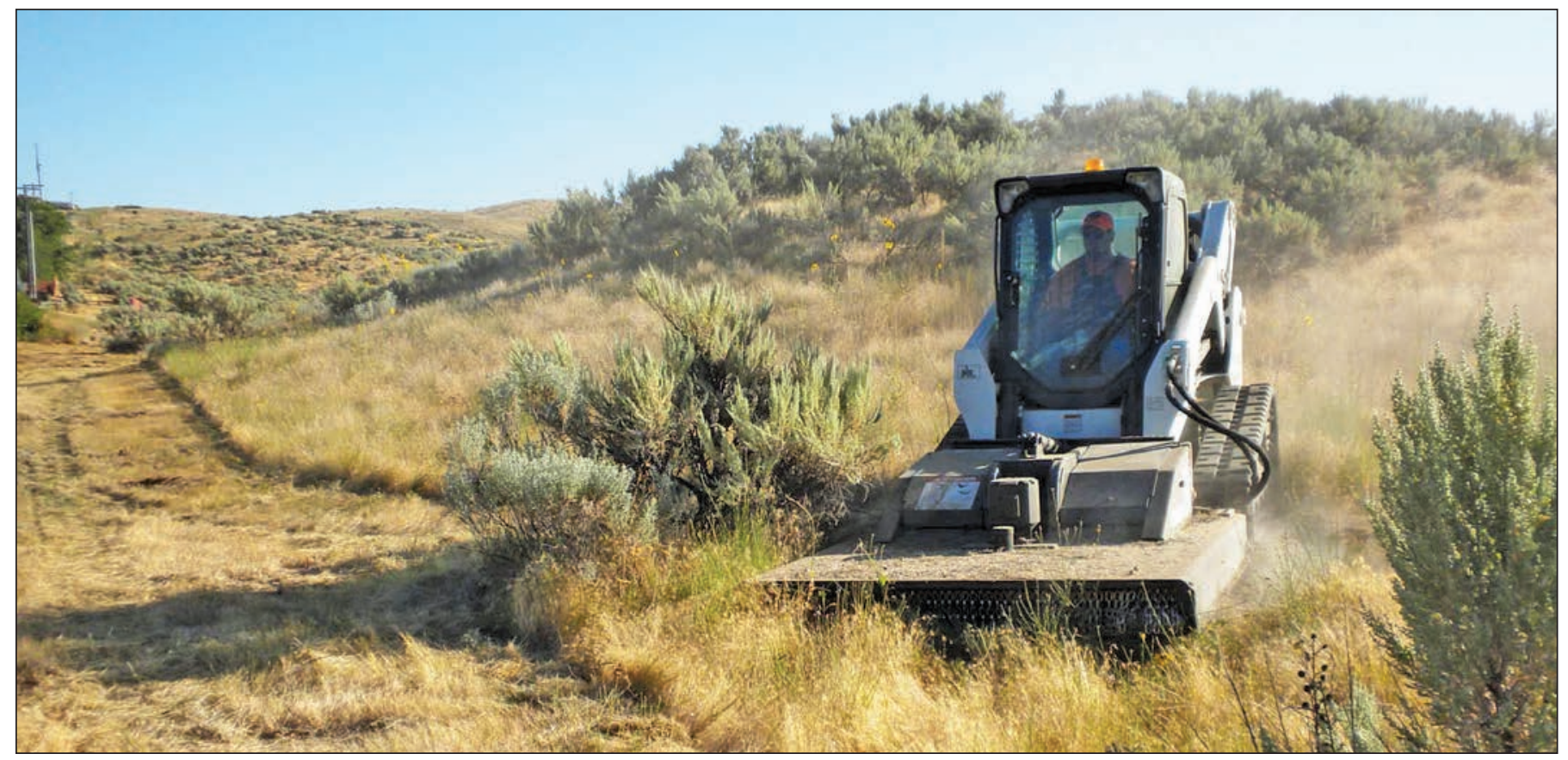

Cooperative Fuels Management Project near Boise, Idaho.

Table 8. Common herbicides used on rangelands for controlling vegetation.

[After Mealor and others (2013) and U.S. Forest Service (2014). A pplication rates: In fluid ounces per acre and (liters per hectare) unless specified otherwise. Abbreviations: cm, centimeter; lb/acre, pound per acre; $\mathrm{kg} / \mathrm{ha}$, kilogram per hectare]

\begin{tabular}{|c|c|c|c|c|}
\hline Chemical name & Trademark name(s) & Application rates & Time of application & Remarks \\
\hline Glyphosate & $\begin{array}{l}\text { Roundup, Rodeo, } \\
\text { Accord and others }\end{array}$ & $\begin{array}{l}12-16 \\
(0.88-1.17)\end{array}$ & $\begin{array}{l}\text { Spring during active growth, but } \\
\text { before early boot stage }\end{array}$ & $\begin{array}{l}\text { Often kills or harms all } \\
\text { plants actively growing }\end{array}$ \\
\hline Imazapic & Plateau, Panoramic & $\begin{array}{l}2-8 \\
\text { (0.15-0.58) depending } \\
\text { on soils }\end{array}$ & $\begin{array}{l}\text { Fall before cheatgrass } \\
\text { emerges or spring before it } \\
\text { reaches } 5 \mathrm{~cm} \text { tall }\end{array}$ & $\begin{array}{l}\text { Pre-emergent or contact } \\
\text { herbicide. Use of surfactant } \\
\text { may impact perennials too. }\end{array}$ \\
\hline $\begin{array}{l}\text { Imazapic } \\
+ \text { glyphosate }\end{array}$ & Journey & $\begin{array}{l}16-21 \\
(1.17-1.54)\end{array}$ & $\begin{array}{l}\text { Fall after cheatgrass } \\
\text { emergence or spring during } \\
\text { active growth }\end{array}$ & $\begin{array}{l}\text { Use as a broad spectrum } \\
\text { herbicide with residual } \\
\text { impact on annual grasses }\end{array}$ \\
\hline Rimsulfuron & Matrix & $\begin{array}{l}2-4 \\
(0.15-0.29)\end{array}$ & Fall or spring & $\begin{array}{l}\text { Broad spectrum herbicide. } \\
\text { Adheres to soil. Soil } \\
\text { movement or drift to } \\
\text { sensitive crops is a concern. }\end{array}$ \\
\hline Sulfosulfuron & Outrider & $\begin{array}{l}0.75-1.33 \\
(0.05-0.11)\end{array}$ & $\begin{array}{l}\text { Fall or spring after until } \\
\text { cheatgrass 3-leaf stage }\end{array}$ & $\begin{array}{l}\text { Contact or root absorption } \\
\text { herbicide, Annual and } \\
\text { perennial weed including } \\
\text { cheatgrass. }\end{array}$ \\
\hline $\begin{array}{l}\text { Sulfometuron } \\
+ \text { Chlorsulfuron }\end{array}$ & Landmark XP & $\begin{array}{l}0.75-1.33 \\
(0.05-0.11)\end{array}$ & $\begin{array}{l}\text { Fall before annual grasses } \\
\text { emerge or spring until } \\
\text { 3-leaf stage. }\end{array}$ & $\begin{array}{l}\text { Broad spectrum herbicide } \\
\text { with residual control that } \\
\text { increases in soils with pH } \\
\text { greater than } 7.5 \text {. May } \\
\text { require one year before } \\
\text { replanting. }\end{array}$ \\
\hline Tebuthiuron & Spike 20P & $\begin{array}{l}2.5-5 \mathrm{lb} / \mathrm{acre} \\
(2.80-5.60 \mathrm{~kg} / \mathrm{ha})\end{array}$ & $\begin{array}{l}\text { Winter or spring allowing } \\
\text { adequate rainfall for soil } \\
\text { infiltration }\end{array}$ & $\begin{array}{l}\text { Woody plant control (higher } \\
\text { rates) or thinning (lower rates). }\end{array}$ \\
\hline $2,4-D$ & $\begin{array}{l}\text { Barrage, Weedone, } \\
\text { Weedar and many more }\end{array}$ & $\begin{array}{l}8-32 \\
(0.59-1.34)\end{array}$ & While actively growing & Broadleaf forbs \\
\hline
\end{tabular}




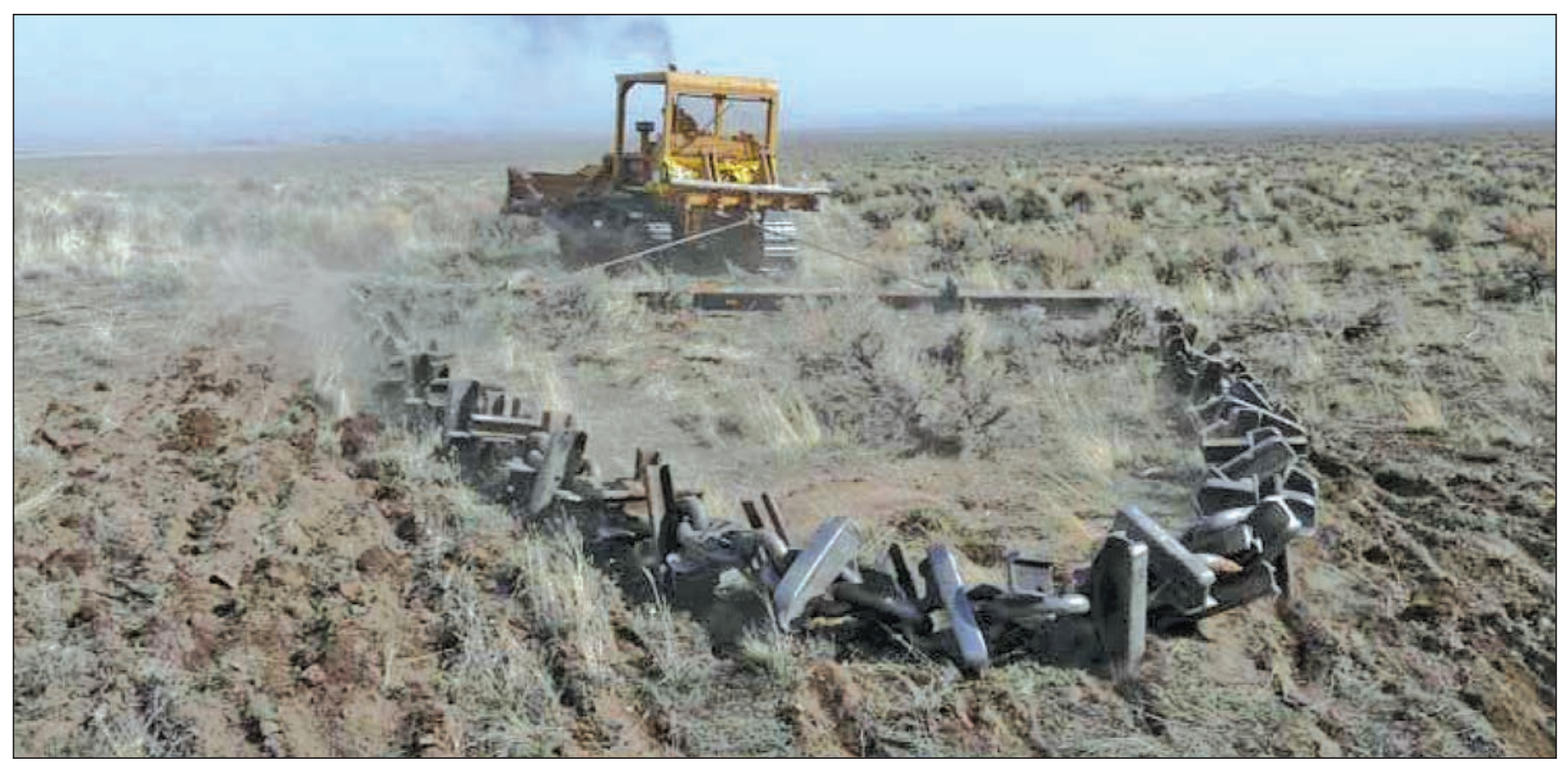

Chain harrow used to partially reduce sagebrush near Rush Valley, Utah.

harm plants that have not emerged from the soil or are present as ungerminated seeds. Multiple applications may be necessary if undesirable plants emerge after applications (for example, in areas with warm- and cool-season undesirable plants). Glyphosate is most effective when plants are at or near their peak relative growth and is less effective as plants are maturing seeds. It is commonly used when few desirable plants are found in the community and invasive plants clearly dominate because all plants contacted by the herbicide will likely die when applied at moderate to high rates. At low rates (for example, 160-350 g acid equivalent/ha) some studies have shown control with limited impact on residual perennial vegetation when applied during active tillering to early boot stage of medusahead (Taeniatherum caput-medusae). Use care when applying these techniques; monitoring both the invasive and residual native plants is recommended to better understand its potential for successful use.

- Imazapic, Rimsulfuron, Sulfosulfuron, Sulfometuron plus Chlorsulfuron. This group of non-selective herbicides when used at low application rates can be somewhat selective in controlling annual plants depending on the timing and rate of application. Modes of action may differ between each, but because of the potential residual effects, they may work as both a pre-emergent and a contact herbicide. It is generally applied in mid- to late-fall before precipitation to work on annual grass seedlings, such as cheatgrass, emerging in fall or winter. At recommended rangeland rates, annual plants fail to emerge, die, or are prevented from producing viable seeds. However, these herbicides also may kill or temporarily harm desirable annual forbs that are used as forage by sage-grouse. If the site is a springsummer habitat for sage-grouse, then these herbicides may not be appropriate for meeting sage-grouse habitat requirements.

Seedings of perennial plants can be implemented just before fall applications of the herbicide, but these applications may have harmful effects on some native species. Munson and others (2015) determined that seedings immediately after wildfires were more successful if imazapic was applied 3 years after seeding rather than the same years as the seeding. Early spring applications, especially in the Intermountain West, may be more harmful to desirable plants because they may be actively growing at the same time as the herbicide application and may contact the herbicide. Applications may reduce cheatgrass competition with desirable native plants during the growth year of application and may reduce densities and competition in the growing season following application and possibly into a third growing season. Adult perennial plants may show signs of injury during the year of application. 
Vigor and seed production may be reduced, leading to decreased cover and seed production, and less potential for new seedling establishment and spread of perennial plants. Do not anticipate a rapid expansion of desirable perennial plants with these herbicides.

- Tebuthiuron. This herbicide when used at low rates has been effective in thinning dense stands of sagebrush and is relatively selective for shrubs and trees. For sagebrush reductions, pelleted formulations with 20 percent active ingredient are used, and application rates are prescribed to reflect the site clay content, soil organic material, current canopy cover of sagebrush, and the desired cover. Pellets dissolve slowly with precipitation and active ingredient is taken up by shrub roots and translocated through the plant. It kills plants by inhibiting photosynthesis. Woody plants appear to be the most sensitive to this herbicide, but broad-leaved herbaceous plants also may be impacted. Some research has shown, however, increases in grass and forb cover with reductions in sagebrush indicating this may be an effective method for thinning dense stands of sagebrush and releasing the perennial herbaceous component in the community, provided herbaceous perennials already exist and invasive annuals are nearly absent in the treatment area (McDaniel and Balliette, 1986).

$-\underline{2,4-\mathrm{D}}$. This is a selective herbicide that acts primarily on dicotyledonous (forbs and woody plants) species. It is a contact herbicide that is most effective when plants are growing actively. It is a synthetic auxin (a plant growth promoting hormone) that results in unsustainable cell division that exhibits its effects as stem and leaf curling of contacted growth points. Within this broad group of plants, it will typically kill the above ground parts of plants. If plants are perennial and capable of resprouting by means of roots, the plant often survives and grows again the following year. It has been commonly used to kill sagebrush since sagebrush is incapable of resprouting. Applications of this herbicide, when forbs are growing actively, will likely impact forbs as well.

- Biological controls.

These include the use of insects or microbes to control populations of undesirable plants. We also will discuss targeted grazing, because regulations for use are less stringent. Most biological control agents are imported from the countries of origin of many undesirable plants.
As a result, there are regulations regarding the import, transport, and use of these organisms. Be certain that exotic biological controls have the appropriate approval for use in your area (consult the U.S. Department of Agriculture, Animal and Plant Health Inspection Service and the U.S. Environmental Protection Agency [EPA]). There are two concerns when using biological controls. One is that the control agent (animal or microbe) must be specific to the plant being controlled. Second, should the agent control the plant then what, if anything, will replace the controlled plant? Revegetation may be necessary to fill the void before another invasive species replaces the one eliminated.

- Insects. Some woody plants and forbs have been successfully controlled with insects. In some cases, these require multiple insects or require the appropriate geographic region. Examples of plants effectively controlled by insects include, but are not limited to: common St. John's Wort (Hypericum perforatum); leafy spurge (Euphorbia esula); saltcedar (Tamarix ramosissima).

- Microbial pathogens. Fungal and bacterial pathogens are currently being tested as biological controls for cheatgrass and other annual invasive grasses. None of these microbes have been successfully shown to be restricted to the target plants (that is, they potentially can attack native desirable plants). These microbes will need to be shown effective on the target invasive plant and must be approved by the EPA as being safe to apply without damaging desirable plants. More study is required to determine if microbial pathogens will be effective control agents.

- Targeted grazing using livestock. This is a form of biological control that does not require permitting, but careful management is required to ensure that the targeted species is the only species negatively impacted by defoliation. In some cases this may require behavioral training of animals to select appropriate plants for control. This may require contracting to obtain trained animals. Good resources when considering targeted grazing can be accessed at the targeted grazing website from the Society for Range Management (https://targetedgrazing. wordpress.com/, accessed December 27, 2016). Match the animal type to the control required and apply the grazing at the most appropriate time for effectiveness. There are four common forms of targeted grazing. 
Fuel breaks using livestock has the goal of reducing fine fuels for wildfire to allow firefighters to actively engage in fire suppression in a safe and strategic manner without committing exhaustive resources to control or contain a wildfire. Sheep, cattle, or goats are commonly used to reduce fine herbaceous fuels in bands or tracks of lands that may be used as fire breaks for firefighters to stop or control fires. These fuel breaks generally must be maintained annually to sustain their effectiveness, especially where herbaceous plants dominate the fuel profile (herbaceous plants are the key component of fine fuels which are key determinants of fire spread and intensity).

Livestock can be used as an agent for weed control, but they may require behavioral training to successfully remove the undesirable plant while insuring the desirable plants are not harmed. As the weed is controlled, it may be necessary to restore a desirable community if desirable plants do not exist on the site in adequate numbers.

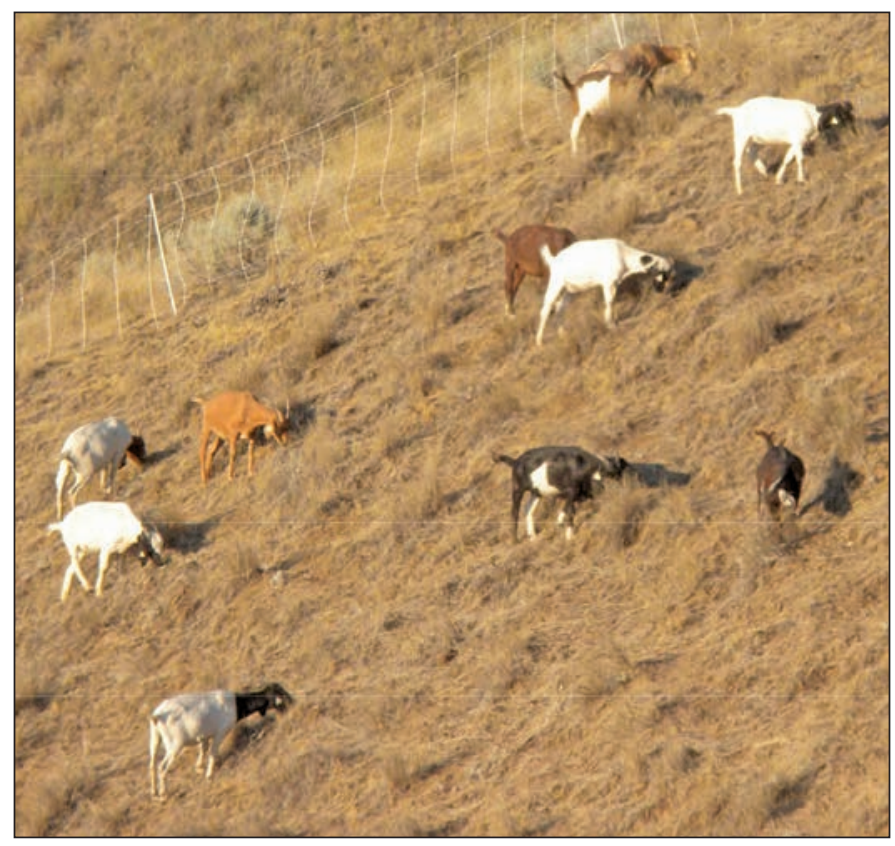

Goat grazing fine fuels in Boise Foothills, near Boise, Idaho.
Livestock may be used to create plant community compositional changes. When it is desirable to shift the dominance of plants within the community, targeted grazing also can be used. This often requires adjustments in the timing of grazing so that the targeted plant is defoliated when it is vulnerable to grazing, but the desired plants are not vulnerable. This may shift the compositional balance in the plant community. The Green-Brown grazing method (Smith and others, 2012) has been proposed as a method suitable for using livestock grazing to create plant community shifts in dominance using native sagebrush steppe as the desired plants and cheatgrass as the target for reduction. To our knowledge, there are no published papers demonstrating success of this method for sagebrush steppe. In addition, if locations for targeted grazing are sage-grouse nesting or brood rearing habitat, then adequate perennial grass height for maintaining habitat guidelines may be required.

Livestock grazing as a site preparation for herbicide application. This technique removes vegetation cover and potential litter that may obstruct herbicide contact on plants or soils. This may reduce herbicide costs while providing forage for livestock.

○ Revegetation.

Restoration of native plants with a goal of achieving an ecosystem similar to the potential for the site, given the soil and current climate, is one form of revegetation. Alternatively, revegetation can be defined as actions to rehabilitate the site, by using similar plant species to those native to the site, but introduced from elsewhere. The rehabilitation plants tend to either achieve additional goals such as increased livestock forage or greater plant competition against invasive plants. A less tested alternative that has been proposed in relation to climate changes is assisted migration, where plants from other areas are matched to the predicted future climate of the area and are planted or sown at the site. We are not advocating this technique until further research can provide better insights on where and when it should be used. 


\section{Big Sagebrush Community Restoration Decisions}

Restoration treatments are prescriptive and may differ among locations. The following are some scenarios with associated passive and active restoration options. Appropriate options will depend on the restoration objectives, current vegetation, amount of desirable and undesirable vegetation on the area, and the resilience and resistance of the site. Ott and others (2016) provide an overview of typical choices and when they are used in the sagebrush communities. Benson and others (2011) provide a more detailed manual focused on the Columbia Plateau region.

\section{If there is too little big sagebrush at restoration site-}

Options for restoring sagebrush will depend on the presence and size of big sagebrush at the site.

1. If big sagebrush is present, but small and young - The best restoration option is to do nothing because it is the least disruptive to the plant community. Maintain current management, prevent fires, monitor for the continued presence of big sagebrush, and wait for it to grow.

2. If big sagebrush is absent, but you desire it-Reintroduction is the best restoration choice because seed banks and seed dispersal are unlikely. Seeding and transplanting are the best reintroduction methods.

Seeding sagebrush- Seeding is done using two general techniques: broadcast by aircraft or

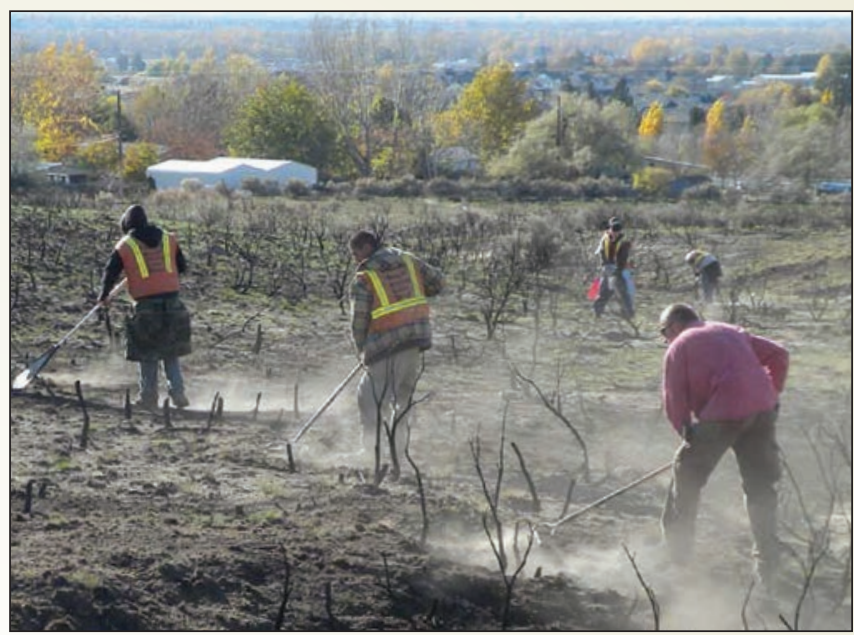

Bureau of Land Management volunteers raking sagebrush seed into the soil after a fire near Boise, Idaho. ground-based broadcast system or drilled.

Broadcasting sagebrush seeds has been generally less successful when done without additional techniques which provide good soil-to-seed contact (soil compacting, harrowing, chaining, and others). Broadcasting also tends to have better success at high elevations with cool and moist soils (moderately high to high resistance to annual grasses and resilience to disturbance) and with low potential for soil erosion. Drilling requires either dribbling the seed directly on the soil surface and packing the seed into the soil with a packing wheel, tractor tire, or tread. Some minimum-till rangeland drills, for example Truax Roughrider ${ }^{\mathrm{TM}}$, have the ability to distribute seed on the soil surface in front of a cultipacker attachment.

Planting sagebrush bareroot stock, tublings, or transplanting wildlings - Tublings have shown the highest success rate for establishing sagebrush. This technique is often more successful than seeding techniques, especially in warmer and drier ecological types with less resistance and resilience. The best conditions for successful plantings require high soil moisture and cold, but not freezing, temperatures.

If big sagebrush dominates the restoration site, but the herbaceous community is not adequate-Passive restoration may be the best option especially if maintenance of big sagebrush is important for sage-grouse. Options in this case will depend on the amount of perennials relative to the amount of invasive annual grasses, but options will be restricted if you wish to maintain the big sagebrush. If active restoration is necessary, then site preparations to remove big sagebrush and revegetate the site may be necessary.

1. If the site has adequate perennial herbaceous species richness, cover, and numbers of deep-rooted perennial grasses to allow passive restoration-Adequate perennial-species richness is at least 2 species of deep-rooted perennial grasses with greater than 5 percent foliar cover and with at least 0.2 plants per $\mathrm{ft}^{2}\left(2\right.$ plants per $\left.\mathrm{m}^{2}\right)$ for these species and the site has high resilience (cold-moist regime). In addition, the cover of deep-rooted perennial bunchgrasses should be at least twice the cover of the invasive annual grasses in a normal growth year. Then the restoration goal should be to enhance cover of the deep-rooted perennial grasses and to encourage establishment of them in interspaces between shrubs. Passive restoration may be successful in high resilience sites. Use of the Green-Brown grazing method may benefit the perennial herbaceous plants and decrease annual grasses. Monitoring to determine if objectives are achieved is critical since research on this lacking. 
2. If the site does not have adequate perennial herbaceous species richness, cover, or numbers as described above or the site meets the above criteria but has moderate resilience (cool-moist regime)_-In these cases, consider spot treatments of imazapic on patches of cheatgrass at rates low enough to kill cheatgrass, but not at rates to kill or harm most of the perennial plants. Additionally, consider temporarily removing livestock grazing until perennial plant vigor has returned. When resuming grazing consider changing grazing management (season of use, intensity of use, distribution, or numbers of livestock) to allow perennial herbaceous plants to reproduce, establish, and persist in interspaces. This may enhance establishment and growth of perennial bunchgrasses, but establishment may require imazapic to adequately degrade in the soil (3 or more years) as well as favorable weather conditions over several years to allow for perennial plant reproduction and establishment. Imazapic also may reduce the cover and density of Sandberg bluegrass (Poa sandbergii). See the section on imazapic for potential side-effects to consider. Monitoring is essential to determine if trends toward meeting restoration objectives are adequate.

3. If deep-rooted perennial grass cover or density is not adequate, but it is at least twice the foliar cover of cheatgrass in a normal growing year, and deep-rooted perennial grasses are found equally under shrubs and in interspaces or more in the interspaces than undershrub-When this is the case, change grazing management to allow the existing deep-rooted perennial grasses to increase cover and to successfully reproduce to provide a seed source for future replacement plants should some grasses die. In addition, consider spot treatments of imazapic on patches of cheatgrass at rates low enough to kill cheatgrass, but not at rates to kill or harm most of the perennial plants. Imazapic may enhance establishment and growth of perennial bunchgrasses, but establishment may require imazapic to adequately degrade in the soil (3 or more years), as well as favorable weather conditions over several years to allow for perennial plant reproduction and establishment. Imazapic also may reduce the cover and density of Sandberg bluegrass (Poa sandbergii), therefore, use caution if Sandburg bluegrass is present. See the section on imazapic for potential side-effects to consider. The ultimate objective should be to achieve nearly 20 percent foliar cover for perennial grasses and to have the majority of this cover contributed by grasses in the interspaces between shrubs. Monitoring is essential since research supporting this is limited.

4. If the site has low resilience and resistance (warm-dry regime)—Responses to passive restoration actions may be slower and more variable than on more productive sites. In these cases, passive techniques may not work within desired time-frames, and active restoration will be difficult and may require multiple interventions to be successful. Restoration of warm-dry sites invaded by annual grasses has proven very difficult, requiring repeated actions and/or multiple treatments in combination. If passive restoration will be attempted, consider fall/winter grazing of cheatgrass by livestock followed by removal of livestock before perennial deep-rooted herbaceous grasses show the first signs of elevating inflorescences in the culms (Green-Brown grazing method). Monitor to determine if deep-rooted perennials are increasing and cheatgrass is decreasing in cover.

5. If soils are shallow with Sandberg bluegrass listed in ecological site descriptions as the dominant perennial grass and is its current foliar cover is greater than 5 percent and at least twice the cover of cheatgrass-Then the restoration goal should be to enhance establishment of Sandberg bluegrass in the interspaces between shrubs to increase resilience. Since these sites tend to have low resistance to cheatgrass and resilience to disturbances, active restoration will likely be difficult, thus passive restoration through changing livestock grazing management to enhance Sandberg bluegrass seed production and seedling establishment in interspaces among shrubs is encouraged to achieve the greater resilience. Care must be taken since Sandberg bluegrass and annual bromes often have similar phenology limiting the grazing opportunity. Livestock need to be removed at or before the elevation of the culms of Sandberg bluegrass to maximize the bluegrass seed production and dispersal while negatively impacting cheatgrass. Grazing may resume after senescence of the bluegrass. This may allow grazing on annual bromes during their reproduction to reduce seed production.

If both big sagebrush and perennial deep-rooted grasses are lacking on the restoration site- Active restoration using a seed drill provides the highest likelihood of successfully restoring the site. The cooler and moister the site, the greater the likelihood of success. On drier and warmer sites with moderately low to low resistance and resilience, seeding in multiple years may be necessary and should be included in the budget since poor weather for germination and establishment is the major deterrent to successful restoration. 
○ Selecting appropriate plant species for revegetation of a site.

Examine the species list for each community phase of the reference state in the S\&T model found in the ecological site description for the location

being revegetated.

- What are the common (constant) native species? Each ecological site description will list the typical plant species found on that ecological site and the range of composition by weight or cover for each species. Species whose compositional range exceeds zero are the most constant species and are often present on the ecological site. They will include the typical dominant species, but also may contain subdominant and minor species. If revegetation is necessary to restore species by seeding or transplanting, then species whose ranges exceed zero would be good candidates for inclusion in restoration projects.

- Select one or more dominant plant species from the major structural and functional plant groups. Each ecological site will have a list of plant species broken into major structural and functional groups. To insure that a diversity of species are restored that will represent these major groups, selecting one or more species from each group may assist the restored plant community to occupy the greatest number of ecological niches within the plant community.

- Selecting native or introduced plant species. In restoration/rehabilitation efforts in the sagebrush steppe, a primary objective should be to ensure the appropriate structural and functional plant species groups are represented in the expected proportions for the specific ecological site(s) in the restoration area to create resilient and resistant ecosystems. For example, seedings may need to include both deep-rooted perennial bunchgrasses (for example, bluebunch wheatgrass) and shallow-rooted grasses (for example, Sandberg bluegrass) to fill different ecological niches if those groups are currently absent from the restoration area. The decision about whether to use native species or comparable introduced species depends on many factors, such as seed availability and cost. Common native grass and shrub species are increasingly available and affordable and will most likely be the desired choice for restoration. Although native forbs are becoming more available, many are still cost prohibitive for large scale seedings. However, seeding patches with forbs may be an option. It will require dedicated seed boxes on drills and the ability to turn the seed delivery on and off.
In many cases, compromises may need to be made to substitute available introduced forbs into the mix. The recent national seed strategy (Plant Conservation Alliance, 2015) may reduce this current reliance on introduced forbs. In the interim, managers can proactively identify important forb species, collect seeds, and contract with growers to increase seeds so they become available when needed. Combining native and introduced grasses in a single mix is not recommended; introduced species often outcompete natives during establishment. The use of all introduced species may be the preferred alternative in some instances, such as, on warm-dry sites with heavy invasive species infestations where the goal is for rapid-establishment, desirable perennials to compete with invasive species. Later additions of native species to add diversity of function and lifeform will likely require multiple interventions, but may still remain a stable state dominated by introduced species and would need to be managed as such.

- What if there are multiple ecological sites on your restoration project area? If the restoration area has more than one ecological site, then three choices may be made.

Separate Ecological Sites. If possible, use physical characteristics of the site to delineate different ecological sites and seed each ecological site with its appropriate species. For example, Digital Elevation Models can sometimes be used to determine slopes or aspects that may distinguish ecological sites when soil map units are not capable of separating these different potential plant communities.

Common Species. If ecological sites cannot be easily separated spatially, then provided they have common species in each ecological site, these common species could be used as the primary species seeding across both sites. In addition, a mixture of minor, sitespecific species from each ecological site might be included in the seed mixture. Given the arid nature of most sagebrush ecological sites, emphasis should be placed on drought-tolerant species.

Mixing Dominant Species. Select the dominant species from the different ecological sites and seed them across two ecological sites. This will allow the separate ecological sites to distinguish where the species will establish, survive, and reproduce. This alternative should only be used as a last resort since it is more costly and will likely result in some species not establishing on portions of the restoration area. 
o Should seeds or transplants be used in the revegetation project?

Sites that require complete reintroduction of all restoration species and are sufficiently large (greater than 2 ha [5 acres]) are often seeded. Since seeding projects often require matching multiple species to multiple sites, their success is often improved by ensuring that the choice of plants adequately matches site conditions. Alternatively, transplants are generally reserved for reintroductions of single species that may initially begin with a small density of plants that can act as the seed source for future plants (for example, shrub islands). In the Intermountain West, this method has been largely used for transplanting shrubs either into existing perennial plant communities that lack shrubs, or for small restoration areas where fast establishment and rapid growth are important (for example, landscaping at historical sites). Another common use of transplants occurs in mined-land reclamation where funds are available to monitor and to sometimes provide additional resources (for example, water or nutrients) if necessary to enhance survival. Alternative approaches used to enhance water capture in arid lands may be worth considering in the future (see Whisenant, 1999; Bainbridge, 2007).

○ Seed Source, Mixture, and Purchase.

When possible, use seeds with origins from the same seed transfer zone of the restoration site. With climate change, some managers may select species from slightly warmer sites than the restoration site, but caution should be used since current minimum temperatures may be as important for establishment as for survival. Further research on the conditions necessary for seedling establishment is crucial before making significant recommendations regarding species selections. Big sagebrush ecosystems cover several ecoregions and many species grow throughout these ecoregions. Seed transfer zones try to encompass similar growing conditions to ensure matches of adaptations with environmental conditions. Thus, knowing information about the source location of plant material to be sown or grown in an area is important especially for species that grow across multiple ecoregions and may be adapted for establishment and survival in their home location, but maladapted for other locations with different growing conditions. If possible, attempt to select species that represent multiple collection areas so as to maximize genetic diversity within the seedlot. This "genetic bulking” of the mix increases the probability that adapted individuals will establish on the site.
- Seed Source-Provisional seed zones. The U.S. Forest Service Western Wildland Environmental Threat Assessment Center has an online tool called Western Threat Mapping Seed Zone GeoBrowser to determine your provisional seed zone (http://www. fs.fed.us/wwetac/threat_map/SeedZones_Intro.html, accessed December 27, 2016). Seeds within the same seed zone should have similar growing conditions. Distance from seed source to site is another method that has been recommended. Preference is given to seed sources within $483 \mathrm{~km}$ (300 mi) of the revegetation site.

- Elevation of source relative to restoration site. Elevation is typically used as a surrogate for temperature and moisture patterns, and selection of native species adapted to comparable conditions is preferable to simple proximity. Preference is given to seed sources with elevations between $500 \mathrm{ft}$ (153 $\mathrm{m}$ ) below to $1000 \mathrm{ft}$ (305 m) above the site, but when considering climate change and its potential impacts these numbers could be reversed.

- Source-Identified Seed. These species are collected at a particular location where the source is maintained in the seed-increase process and is provided in the label information for the seed lot.

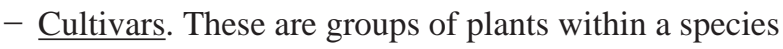
that have been chosen and maintained because of growth performance qualities for certain areas. In some cases, identification can be traced to a single accession (collection site) or multiple accessions. However, sometimes accessions are bulked and the better performing plants are chosen for the cultivar. Some cultivars may result from some genetic manipulations through breeding. Read the cultivar release information to determine origin and environmental requirements and match those requirements to the revegetation site.

○ Determine the amount of seed required per species.

This requires information on the area of land that will be seeded and the proportion of the seed mixture that each species will contribute. The amount of seed will be calculated based on the amount of Pure Live Seed (PLS) in the seed mixture and the desired density of plants after treatment. 
- Percent PLS calculation. PLS is calculated as the quotient of percent Purity (from seed tag) and percent Germination (Germ, including percent Viable, but dormant from laboratory tests using tetrazolium chloride) of the seeds available [percent PLS = (percent Purity $\times$ percent Germ)/100]. The seed tag has a value, but it is recommended to obtain an independent test. Seeds are purchased as bulk seeds in pounds, but the quality of seed may vary, thus the importance in knowing the percent PLS within the purchased bulk seed. Ensure that documentation of the source and percent PLS of all species used in a seed mix is included in the implementation monitoring report for evaluation and adaptation after treatment.

- Determine number of PLS per unit weight. Bulk seed is purchased by weight, but seeds vary in size, so the average number of seeds per unit weight must be determined. These estimates are known for the majority of species in the sagebrush steppe. There are four sources for this information and each may differ in their exact values: (1) The USDA Web page, PLANTS Database, (http://plants.usda.gov, accessed December 27, 2016) is currently under revision and validation so may have limited species. On this Web page, search for the plant species, then select Characteristics from General Information box (on the left side of the screen) to find Seed per Pound (this is the PLS per pound); (2) Jorgensen and Stevens (2004; table 1; http://www.treesearch.fs.fed.us/pubs/31970; accessed December 27, 2016) provides an extensive list of grasses, forbs, and shrubs for western rangelands; (3) "Guidebook to Seeds of Native and Non-native Grasses, Forbs and Shrubs of the Great Basin" by Scott Lambert (2005; table C, http://www. blm.gov/style/medialib/blm/id/publications/technical_ bulletins.Par.93717.File.dat/tb05-04.pdf, accessed December 27, 2016); or (4) download Bulk Seed Calculator Spreadsheet (http://fresc.usgs.gov/sites/ ESRMonitoring/Tools.htm, accessed December 27, 2016) to obtain species PLS per pound from an earlier version of the PLANTS Database preloaded for States of Idaho, Nevada, Oregon, and Utah, (table 9). This spreadsheet also is preloaded with calculations to assist in the following steps for determining the amount of seed to purchase.
- Determine the fully occupied seeding rate per species. The Fully Occupied Seeding Rate is the number of PLS necessary for the species to establish a fully occupied stand of this species alone. Standard seed rates are set to about $25 \mathrm{PLS} / \mathrm{ft}^{2}\left(250 \mathrm{PLS} / \mathrm{m}^{2}\right)$ for most species; these rates are adjusted upwards to about $45 \mathrm{PLS} / \mathrm{ft}^{2}\left(450 \mathrm{PLS} / \mathrm{m}^{2}\right)$ for small-seeded species ( $\geq 50,000 \mathrm{PLS} / \mathrm{lb}$ or $110,132 \mathrm{PLS} / \mathrm{kg}$ ). By dividing PLS/ft ${ }^{2}\left(\mathrm{PLS} / \mathrm{m}^{2}\right)$ by PLS/lb (PLS/kg) and multiplying by $43,560 \mathrm{ft}^{2} /$ acre $\left(10,000 \mathrm{~m}^{2} / \mathrm{ha}\right)$ you will get the fully occupied seed rate in lb of PLS/acre (kg of PLS/ha).

- Determine the percent of the mixture that each species will contribute to the stand. This percentage should be based on the manager's perspective of the ultimate proportional densities (relative densities) that each species would each contribute to the overall densities of plants across the revegetation area. Note that the established stand of seeded species is not directly correlated to the proportion of the seed of each species in the seed mix. Monitoring and local experience can help to refine these proportions in future restoration projects. If there are residual plants that exist on the site at the time of the restoration, then these also should be considered in the overall mixture, therefore the seeded mixture might be less than 100 percent of the overall fully occupied stand.

- Actual seed rates. These are calculated by multiplying the percent of the mixture for each species times the Fully Occupied Seed Rate.

- Weight of PLS seed required for the project. Seeds are purchased based on the weight of seed for each species that is required for the project. This value is calculated by multiplying the Actual Seed Rate (lb PLS/acre) times the area (acres) of the project. If seeds will be broadcast onto a site rather than drilled into the soil, then this seed weight is typically doubled, to double the number of seeds sown. The Weight of Bulk seed would be the Weight of PLS divided by the percent PLS of the seed being purchased.

- Seed cost. This will be calculated based on the weight of PLS purchased for each species. 


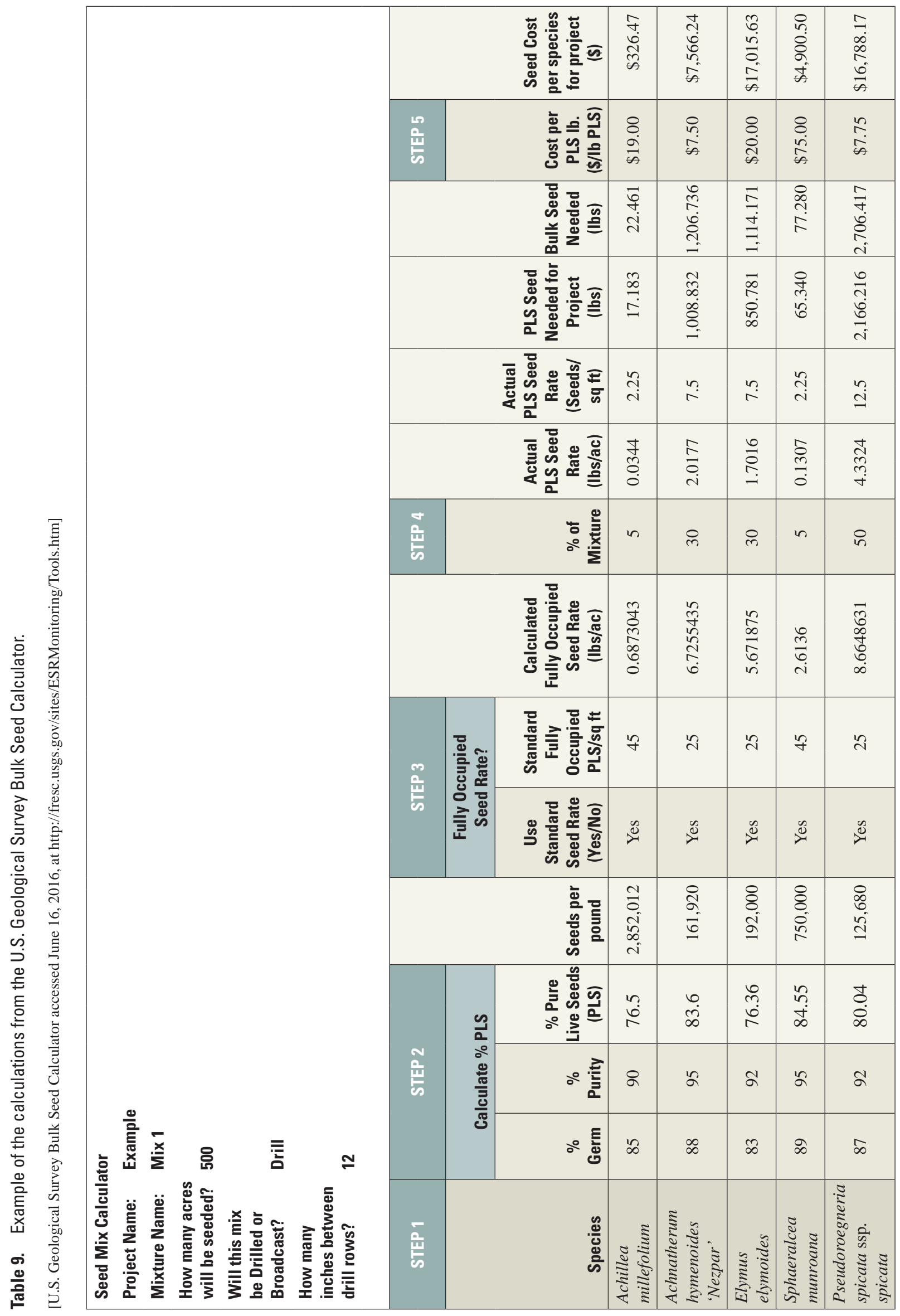


o Consider treating some seeds to enhance germination and establishment.

Breaking dormancy and inoculating seeds with specific bacteria or fungi to enhance germination or establishment may be considered for some species. Species with thick or indurate seed coats often have a physical dormancy that must be broken before the seed can imbibe and germinate. Equipment to break the seed coat can be used on some species whereas others perform better with acid pretreatments. Inoculations of rhizobacteria for legume species and of mycorrhiza for obligate mycorrhizal associated plants may improve establishment. It is a good practice to examine plant fact sheets and plant guides for species in a seeding mixture to determine if they require additional treatments to enhance establishment. The PLANTS Database (http:// plants.usda.gov) is an excellent initial resource for these materials, but also online searches may reveal available literature or other online sources. Examples of propagation techniques can be accessed at http://npn. rngr.net/propagation (accessed December 27, 2016).

○ Group species by the sowing depth of their seeds.

This applies to drill-sown seeds. The optimum depth of a seed depends on the seed size and light and temperature requirements for germination. If seeds require light to germinate, then they must be planted at the soil surface. Those requiring fluctuating temperatures should be buried, but near the surface. Otherwise, the general rule is to sow seeds at depths equal to about 2.5 to 3 times the seed length if oblong or diameter if round (tables 10 and 11).
○ Seed mixing before application.

Seeds sown at similar depths should be mixed and sown together. Rice hulls (U.S. No. 1 grade) are often mixed with small seeds to insure that seeds are sown evenly. The rice hulls work as cups to hold small seeds and allow them to pass through a seed drill in an even manner during the drilling process. A guide for mixing rice hulls (St. John and others, 2012) can be accessed at: https:/www.nrcs.usda.gov/Internet/ FSE_PLANTMATERIALS/publications/idpmctn5976a. pdf (accessed December 27, 2016).

○ Sowing seeds.

The preference for restoration success is to use a seed drill to sow seeds, but this depends on the steepness of the slope and the stoniness of the soils. If a seed drill is not possible, then broadcasting seeds can be done.

- When to seed. Seeding should be done just before or at the beginning of the onset of the most prominent and predictable period of precipitation to insure adequate moisture for germination and establishment. In the Great Basin, Columbia Basin, and Snake River Plain floristic provinces this is typically in late-fall to early-winter. In the eastern and some southern provinces, this may shift to late-spring if summer precipitation is the most reliable source of precipitation. Check with the local NRCS offices to understand site-specific recommendations. Near-term weather forecasts may provide additional insights (or restrictions) on planting activities.

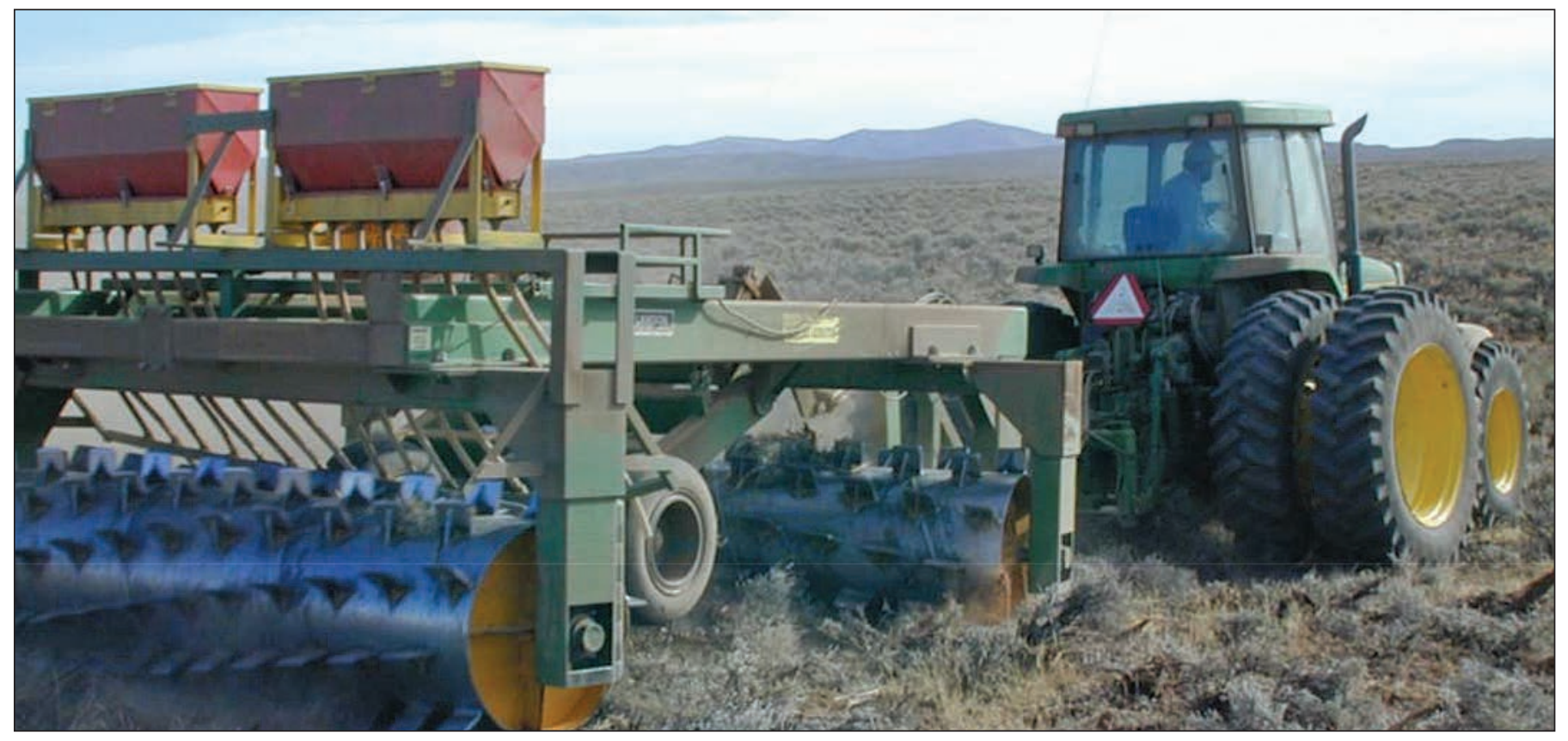

Meadow aerator-seeder planting seeds while aerating the soil near Evanston, Wyoming. 
Table 10. Seeding recommendation for grasses, forbs, and shrubs provided by Monsen and Stevens (2004, p. 135).

[Date: F, fall to winter; S, early spring. M ethod: A, aerial or ground broadcast; B, drill; C, surface compact seeding; D, browse interseeder. Depth: A, surface to 0.12 inches (in.) or 3.0 millimeters (mm) deep; B, 0.12-0.25 in. (1.6-6.4 mm) deep; C, 0.25-0.75 in. (6.4-19 mm) deep; D, greater than 0.75 in. (19 mm) deep. Compatibility with other species: $1-5$ with 5 being highly compatible. Vigor: $1-5$ with 5 having high seed vigor. G rowth rate: $1-5$ with 5 having the highest rate of growth]

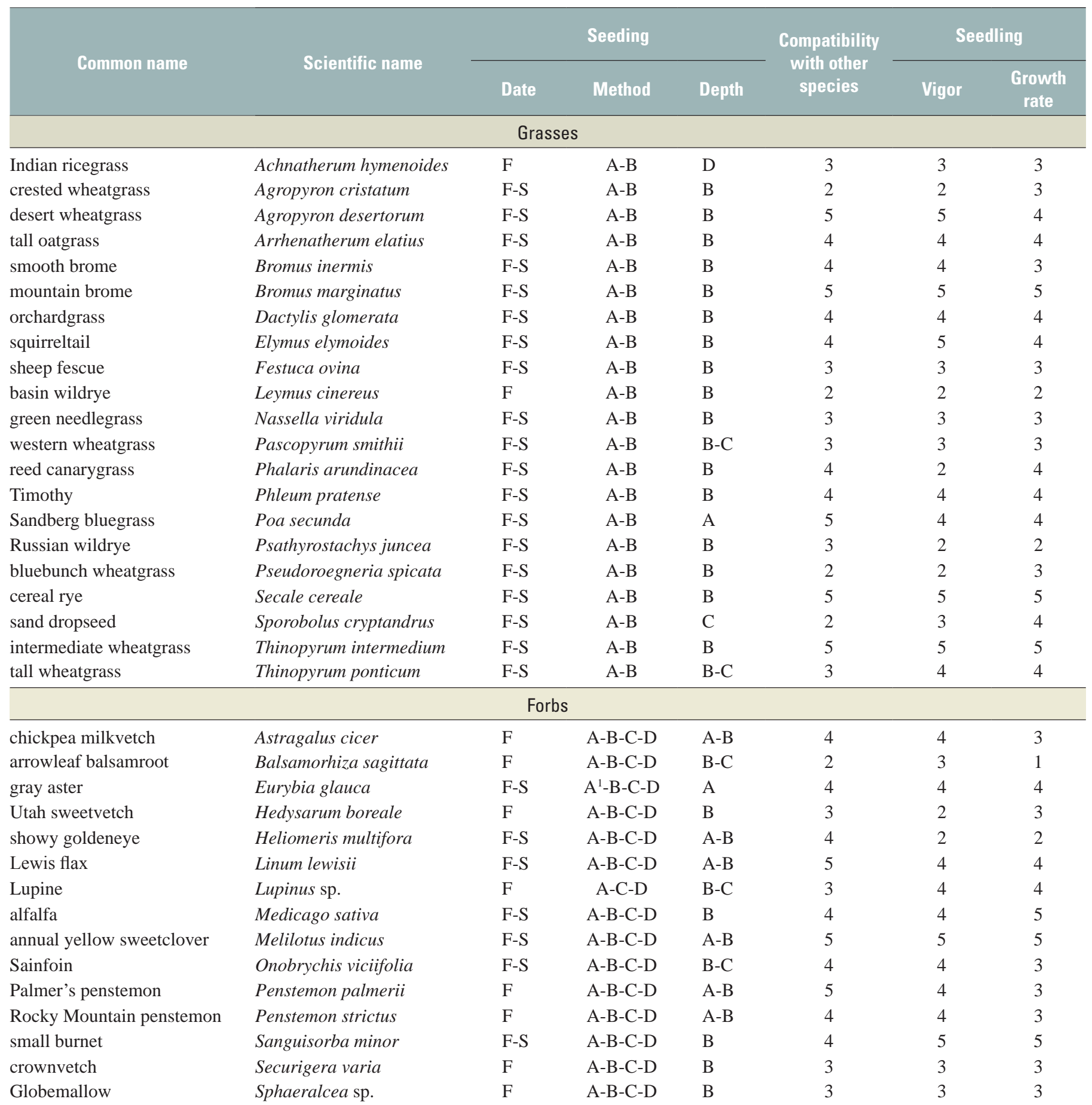


Table 10. Seeding recommendation for grasses, forbs, and shrubs provided by Monsen and Stevens (2004, p. 135).—Continued

\begin{tabular}{|c|c|c|c|c|c|c|c|}
\hline Common name & Scientific name & Date & Method & Depth & $\begin{array}{l}\text { Compatibility } \\
\text { with other } \\
\text { species }\end{array}$ & Vigor & $\begin{array}{l}\text { Growth } \\
\text { rate }\end{array}$ \\
\hline \multicolumn{8}{|c|}{ Shrubs } \\
\hline Saskatoon serviceberry & Amelanchier alnifolia & $\mathrm{F}$ & C-D & B & 3 & 3 & 3 \\
\hline mountain big sagebrush & $\begin{array}{l}\text { Artemisia tridentata ssp. } \\
\text { vaseyana }\end{array}$ & F-S & $A-B^{1}-C^{2}-D^{2}$ & A & 4 & 5 & 4 \\
\hline Wyoming big sagebrush & $\begin{array}{l}\text { Artemisia tridentata ssp. } \\
\text { wyomingensis }\end{array}$ & F-S & $A-B^{1}-C^{2}-D^{2}$ & A & 3 & 4 & 4 \\
\hline alderleaf mountain mahogany & Cercocarpus montanus & $\mathrm{F}$ & B-C-D & $\mathrm{B}$ & 3 & 3 & 3 \\
\hline yellow rabbitbrush & Chrysothamnus viscidiflorus & F-S & $A-B^{1}-C^{2}-D^{2}$ & A & 5 & 5 & 4 \\
\hline mormon tea & Ephedra viridis & $\mathrm{F}$ & B-C-D & B & 3 & 2 & 2 \\
\hline rubber rabbitbrush & Ericameria nauseosa & F-S & $A-B^{1}-C^{2}-D^{2}$ & A & 5 & 5 & 4 \\
\hline winterfat & Krascheninnikovia lanata & F-S & $A-B^{1}-C^{2}-D^{2}$ & A & 4 & 5 & 3 \\
\hline chokecherry & Prunus virginiana & $\mathrm{F}$ & B-C-D & $\mathrm{B}-\mathrm{C}$ & 2 & 2 & 2 \\
\hline Stansbury cliffrose & Purshia stansburiana & $\mathrm{F}$ & B-C-D & $\mathrm{B}-\mathrm{C}$ & 3 & 3 & 2 \\
\hline antelope bitterbrush & Purshia tridentata & $\mathrm{F}$ & B-C-D & B-C & 4 & 5 & 4 \\
\hline Gambel Oak & Quercus gambelii & $\mathrm{F}$ & C-D & $\mathrm{C}$ & 1 & 2 & 2 \\
\hline skunkbush sumac & Rhus trilobata & $\mathrm{F}$ & C-D & B & 2 & 2 & 2 \\
\hline
\end{tabular}

${ }^{1}$ If cleaned to 60 percent or greater purity.

${ }^{2}$ If cleaned to 30 percent purity.

- Drill seeds when slopes are less than 30 percent and soils are not stony (less than 15 percent surface stones [greater than 9.8 in., or $250 \mathrm{~mm}$ ]). Recent developments of rangeland drills have improved on the original design with only one seed box. Minimum till drills are now available with multiple seed boxes that can incorporate different sizes and shapes of seeds and that control seed depth better than in the past. Regardless of the type of drill used, the drill should be calibrated before seeding and recalibrated during the seeding process. Geographic Position Systems (GPS) can be attached to the tractor pulling the drill to assist in determining the seeding rate across a project and to document the actual areas seeded. Appendix C provides description of calibration techniques for rangeland drills.
- Broadcast seeding. This can be accomplished using ground applied equipment or by aircraft. As with seed drills, use of a GPS allows more precise applications across lands and should be considered for improving seeding coverage. Broadcast seeding tends to be less successful unless it is followed immediately with techniques to incorporate seeds into the soils. Calibration of broadcast seeders also is important before and during applications, but the precision of these calibrations is less than on seed drills. For ground-based equipment, tarps are placed in the path of the seeder. Seed counts per area and adjustments are repeated until the seed rate is appropriate. Generally, there is some overlap of broadcast paths to compensate for the seed rate reduction; therefore, seed rates at different distances should guide the necessary overlap in seeding paths. 
Table 11. Seeding recommendations for grasses, forbs, and shrubs provided by Lambert (2005, p. 87-91).

[Great Basin plant species showing nativity, soils adapted to, average plant height at maturity, and placement in soil. Native status: I, introduced to western North America; N, native to specified geographic area in western North America. Soils: cl , clay loam; 1, loam; s, sands; sil, silt loam; sl , sandy loam]

\begin{tabular}{|c|c|c|c|c|c|}
\hline Common name & Scientific name & $\begin{array}{l}\text { Native } \\
\text { status }\end{array}$ & Soils & $\begin{array}{c}\text { Plant } \\
\text { height } \\
\text { (inches) }\end{array}$ & $\begin{array}{l}\text { Seed } \\
\text { depth } \\
\text { (inches) }\end{array}$ \\
\hline \multicolumn{6}{|c|}{ Grasses } \\
\hline Indian ricegrass & Achnatherum hymenoides & $\mathrm{N}$ & s, sl & 28 & $2-8$ \\
\hline desert needlegrass & Achnatherum speciosum & $\mathrm{N}$ & sl & 30 & $1 / 2$ \\
\hline Thurber's needlegrass & Achnatherum thurberianum & $\mathrm{N}$ & sil, sl, shallow, rocky & 30 & $1 / 2$ \\
\hline crested wheatgrass & Agropyron cristatum & I & l, sil & 36 & $1 / 4-1 / 2$ \\
\hline Siberian wheatgrass & Agropyron fragile & I & sl & 30 & $1 / 4-1 / 2$ \\
\hline purple threeawn & Aristida purpurea & $\mathrm{N}$ & sil, sl & 16 & $1 / 4-1 / 2$ \\
\hline sideoats grama & Bouteloua curtipendula & $\mathrm{N}$ & sil, sl & 30 & $1 / 4$ \\
\hline bluegrama & Bouteloua gracilis & $\mathrm{N}$ & $\mathrm{cl}, \mathrm{sl}$ & 16 & $1 / 8-1 / 4$ \\
\hline meadow brome & Bromus biebersteinii & I & l, deep & 42 & $1 / 4-1 / 2$ \\
\hline smooth brome & Bromus inermis & I & l, sil, deep & 48 & $1 / 4-1 / 2$ \\
\hline mountain brome & Bromus marginatus & $\mathrm{N}$ & l, sil, deep & 48 & $1 / 4-1 / 2$ \\
\hline orchardgrass & Dactylis golmerata & I & l, sil & 48 & $1 / 4-1 / 2$ \\
\hline California oatgrass & Danthonia californica & $\mathrm{N}$ & l, cl, sil & 32 & $1 / 4-1 / 2$ \\
\hline timber oatgrass & Danthonia intermedia & $\mathrm{N}$ & sl, l & 24 & $1 / 2$ \\
\hline tufted hairgass & Deshampsia cespitosa & $\mathrm{N}$ & cl, sil, acidic & 24 & $1 / 8$ \\
\hline saltgrass & Distichilis spicata & $\mathrm{N}$ & cl, sil, alkali & 16 & $1 / 8-1 / 4$ \\
\hline squirreltail & Elymus elymoides & $\mathrm{N}$ & sil, sl & 24 & $1 / 4$ \\
\hline blue wildrye & Elymus glaucus & $\mathrm{N}$ & l, sil & 36 & $1 / 4-1 / 2$ \\
\hline RS wheatgrass & Elymus hoffmannii & I & sil & 36 & $1 / 4-1 / 2$ \\
\hline thickspike wheatgrass & Elymus lanceolatus & $\mathrm{N}$ & s, sil & 36 & $1 / 4-1 / 2$ \\
\hline streambank wheatgrass & Elymus lanceolatus ssp. lanceolatus & $\mathrm{N}$ & l, sil & 36 & $1 / 4-1 / 2$ \\
\hline big squirreltail & Elymus multisetus & $\mathrm{N}$ & sil, sl & 28 & $1 / 4$ \\
\hline slender wheatgrass & Elymus trachycaulus & $\mathrm{N}$ & l, sl, saline & 40 & $1 / 4-1 / 2$ \\
\hline Snake River wheatgrass & Elymus wawawaiensis & $\mathrm{N}$ & sl, sil & 36 & $1 / 4-1 / 2$ \\
\hline hard fescue & Festuca brevipila & $\mathrm{I}$ & l, sil & 18 & $1 / 4$ \\
\hline Idaho fescue & Festuca idahoensis & $\mathrm{N}$ & cl, sil & 32 & $1 / 4$ \\
\hline Roemer's fescue & Festuca idahoensis ssp. roemeri & $\mathrm{N}$ & cl, sil, (W.OR) & 30 & $1 / 4$ \\
\hline western fescue & Festuca occidentalis & $\mathrm{N}$ & sil & 24 & $1 / 4$ \\
\hline sheep fescue & Festuca ovina & I & l, sil & 14 & $1 / 4$ \\
\hline creeping red fescue & Festuca rubra ssp. arenaria & I & l, sil, acidic & 24 & $1 / 4$ \\
\hline needle and thread & Hesperostipa comata & $\mathrm{N}$ & s, sl & 30 & $1 / 2$ \\
\hline prairie Junegrass & Koeleria macrantha & $\mathrm{N}$ & sil, sl & 24 & $1 / 8$ \\
\hline basin wildrye & Leymus cinereus & $\mathrm{N}$ & sil, sl & 60 & $1 / 4-1 / 2$ \\
\hline mammoth wildrye & Leymus racemosus & I & $\mathrm{s}$ & 40 & $1 / 2$ \\
\hline beardless wildrye & Leymus triticoides & $\mathrm{N}$ & sl & 40 & $1 / 2$ \\
\hline green needlegrass & Nassella viridula & $\mathrm{N}$ & cl, shale-derived & 40 & $1 / 2$ \\
\hline western wheatgrass & Pascopyrum smithii & $\mathrm{N}$ & $\mathrm{cl}, \mathrm{l}$ & 36 & $1 / 4-1 / 2$ \\
\hline James’ galleta & Pleuraphis jamesii & $\mathrm{N}$ & $\mathrm{cl}, \mathrm{l}$ & 18 & $1 / 4$ \\
\hline Canada bluegrass & Poa compressa & I & l & 16 & $1 / 8$ \\
\hline Cusick’s bluegrass & Poa cusickii & $\mathrm{N}$ & sil, sl & 16 & $1 / 8$ \\
\hline muttongrass & Poa fendleriana & $\mathrm{N}$ & l, sil & 20 & $1 / 8$ \\
\hline Sandberg bluegrass & Poa secunda & & & & \\
\hline alkali bluegrass & Poa juncifolia & $\mathrm{N}$ & sil, alkali & 26 & $1 / 8$ \\
\hline big bluegrass & Poa ampla & $\mathrm{N}$ & l, sil & 24 & $1 / 8$ \\
\hline Canby’s bluegrass & Poa canbyi & $\mathrm{N}$ & l, sil & 20 & $1 / 8$ \\
\hline Nevada bluegrass & Poa nevadensis & $\mathrm{N}$ & sil, sl & 30 & $1 / 8$ \\
\hline Sandberg’s bluegrass & Poa sandbergii & $\mathrm{N}$ & l, sil & 16 & $1 / 8$ \\
\hline Russian wildrye & Psathyrostachys juncea & I & sil, sl & 32 & $1 / 4-1 / 2$ \\
\hline bluebunch wheatgrass & Pseudoroegneria spicata & $\mathrm{N}$ & sil & 40 & $1 / 4-1 / 2$ \\
\hline
\end{tabular}


38 Restoration Handbook for Sagebrush Steppe Ecosystems with Emphasis on Greater Sage-Grouse Habitat—Part 3

Table 11. Seeding recommendations for grasses, forbs, and shrubs provided by Lambert (2005, p. 87-91)._-Continued

\begin{tabular}{|c|c|c|c|c|c|}
\hline Common name & Scientific name & $\begin{array}{l}\text { Native } \\
\text { status }\end{array}$ & Soils & $\begin{array}{c}\text { Plant } \\
\text { height } \\
\text { (inches) }\end{array}$ & $\begin{array}{l}\text { Seed } \\
\text { depth } \\
\text { (inches) }\end{array}$ \\
\hline \multicolumn{6}{|c|}{ Grasses-Continued } \\
\hline beardless wheatgrass & Pseudoroegneria spicata ssp. inermis & $\mathrm{N}$ & sil & 40 & $1 / 4-1 / 2$ \\
\hline alkali sacaton & Sporobolus airoides & $\mathrm{N}$ & $\mathrm{l}, \mathrm{sl}$ & 36 & $1 / 8$ \\
\hline sand dropseed & Sporobolus cryptandrus & $\mathrm{N}$ & s, sl & 30 & $1 / 8$ \\
\hline intermediate wheatgrass & Thinopyrum intermedium & I & sil & 48 & $1 / 4-1 / 2$ \\
\hline tall wheatgrass & Thinopyrum ponticum & $\mathrm{I}$ & l, sil, & 60 & $1 / 4-1 / 2$ \\
\hline sixweeks fescue & Vulpia octoflora & $\mathrm{N}$ & annual sil & 12 & $1 / 4$ \\
\hline \multicolumn{6}{|c|}{ Wildflowers including herbaceous legumes } \\
\hline western yarrow & Achillea millefolium & $\mathrm{N}$ & sil, l & 24 & $1 / 8-1 / 4$ \\
\hline tapertip onion & Allium acuminatum & $\mathrm{N}$ & sil, l & 24 & $1 / 4-1 / 2$ \\
\hline milkweed & Asclepias species & $\mathrm{N}$ & sil, sl & 36 & $1 / 2$ \\
\hline chickpea milkvetch & Astragalus cicer & $\mathrm{I}$ & sil, sl & 36 & $1 / 4-1 / 2$ \\
\hline basalt milkvetch & Astragalus filipes & $\mathrm{N}$ & sil, sl & 36 & $1 / 4-1 / 2$ \\
\hline freckled milkvetch & Astragalus lentiginosus & $\mathrm{N}$ & sil, sl, cl & 16 & $1 / 4$ \\
\hline woollypod milkvetch & Astragalus purshii & $\mathrm{N}$ & sil, l & 20 & $1 / 2$ \\
\hline Silver’s milkvetch & Astragalus subcinereus & $\mathrm{N}$ & sil, sl & 12 & $1 / 4$ \\
\hline looseflower milkvetch & Astragalus tenellus & $\mathrm{N}$ & sil, sl & 24 & $1 / 4$ \\
\hline Carey’s balsamroot & Balsamorhiza careyana & $\mathrm{N}$ & sil, sl & 46 & $1 / 2$ \\
\hline Hooker’s balsamtoot & Balsamorhiza hookeri & $\mathrm{N}$ & sil & 42 & $1 / 2$ \\
\hline arrowleaf balsamroot & Balsamorhiza sagittata & $\mathrm{N}$ & sil, sl & 48 & $1 / 2$ \\
\hline Gunnison’s mariposa lily & Calochortus gunnisonii & $\mathrm{N}$ & sl, sil & 18 & $1 / 4$ \\
\hline sagebrush mariposa lily & Calochortus macrocarpus & $\mathrm{N}$ & sl, sil & 18 & $1 / 4$ \\
\hline small camas & Camassia quamash & $\mathrm{N}$ & sil, l, cl & 24 & $1 / 4-1 / 2$ \\
\hline yellow spiderflower & Cleome lutea & $\mathrm{N}$ & sil, sl & 28 & $1 / 4$ \\
\hline Rocky Mountain beeplant & Cleome serrulata & $\mathrm{N}$ & sil, l & 36 & $1 / 4$ \\
\hline tapertip hawksbeard & Crepis acuminata & $\mathrm{N}$ & sil, sl & 28 & $1 / 4$ \\
\hline Blue Mountain prairie clover & Dalea ornata & $\mathrm{N}$ & sl & 30 & $1 / 4-1 / 2$ \\
\hline dwarf yellow fleabane & Erigeron chrysopsidis & $\mathrm{N}$ & sil, sl & 10 & $1 / 4$ \\
\hline desert yellow fleabane & Erigeron linearis & $\mathrm{N}$ & sil, sl & 12 & $1 / 4$ \\
\hline shaggy fleabane & Erigeron pumulis & $\mathrm{N}$ & sil & 20 & $1 / 4$ \\
\hline showy aster & Eurybia conspicua & $\mathrm{N}$ & sl, sil, l & 36 & $1 / 4-1 / 2$ \\
\hline blanketflower & Gaillardia aristata & $\mathrm{N}$ & sil, 1 & 24 & $1 / 4$ \\
\hline sticky purple geranium & Geranium viscosissimum & $\mathrm{N}$ & sil & 24 & $1 / 8$ \\
\hline northern sweetvetch & Hedysarum boreale & $\mathrm{N}$ & sil & 30 & $1 / 4$ \\
\hline common sunflower & Helianthus annuus & $\mathrm{N}$ & sl, sil & 60 & $1 / 4-1 / 2$ \\
\hline showy goldeneye & Heliomeris multiflora & $\mathrm{N}$ & sil & 48 & $1 / 4$ \\
\hline scarlet gilia & Ipomopsis aggregata & $\mathrm{N}$ & sil, sl & 36 & $1 / 4$ \\
\hline Bonneville pea & Lathyrus brachycalyx & $\mathrm{N}$ & sil & 24 & $1 / 4-1 / 2$ \\
\hline granite prickly phlox & Linanthus pungens & $\mathrm{N}$ & sil, sl & 24 & $1 / 4$ \\
\hline Lewis' flax & Linum lewisii & $\mathrm{N}$ & sil, sl & 28 & $1 / 4$ \\
\hline blue flax & Linum perenne & I & sl, sil & 30 & $1 / 4$ \\
\hline cous biscuitroot & Lomatium cous & $\mathrm{N}$ & sil, sl & 36 & $1 / 8-1 / 4$ \\
\hline fernleaf biscuitroot & Lomatium dissectum & $\mathrm{N}$ & sil & 30 & $1 / 8-1 / 4$ \\
\hline Gray’s biscuitroot & Lomatium grayi & $\mathrm{N}$ & sil & 30 & $1 / 8-1 / 4$ \\
\hline bird’s-foot trefoil & Lotus corniculatus & I & sil, cl, l & 18 & $1 / 4$ \\
\hline big deer vetch & Lotus crassifolius & $\mathrm{N}$ & sil, sl & 24 & $1 / 4-1 / 2$ \\
\hline Nevada bird’s-foot trefoil & Lotus nevadensis & $\mathrm{N}$ & sl, shallow & 20 & $1 / 4$ \\
\hline meadow bird’s-foot trefoil & Lotus pinnatus & $\mathrm{N}$ & sil & 20 & $1 / 4$ \\
\hline silver lupine & Lupinus albifrons & $\mathrm{N}$ & sl, sil & 18 & $1 / 4-1 / 2$ \\
\hline silky lupine & Lupinus sericeus & $\mathrm{N}$ & sl, sil & 18 & $1 / 4-1 / 2$ \\
\hline annual yellow sweetclover & Melilotus indicus & $\mathrm{I}$ & sil, sl & 48 & $1 / 4$ \\
\hline blazing-star & Mentzelia species & $\mathrm{N}$ & sl & 36 & $1 / 4$ \\
\hline alfalfa & Meticago sativa & I & sl, sil, l & 36 & $1 / 4-1 / 2$ \\
\hline
\end{tabular}


Table 11. Seeding recommendations for grasses, forbs, and shrubs provided by Lambert (2005, p. 87-91).—Continued

\begin{tabular}{|c|c|c|c|c|c|}
\hline Common name & Scientific name & $\begin{array}{l}\text { Native } \\
\text { status }\end{array}$ & Soils & $\begin{array}{l}\text { Plant } \\
\text { height } \\
\text { (inches) }\end{array}$ & $\begin{array}{l}\text { Seed } \\
\text { depth } \\
\text { (inches) }\end{array}$ \\
\hline \multicolumn{6}{|c|}{ Wildflowers including herbaceous legumes-Continued } \\
\hline nodding microseris & Microseris nutans & $\mathrm{N}$ & sil, sl & 16 & $1 / 4$ \\
\hline Sainfoin & Onobrychis viciifolia & I & sl, sil & 24 & $1 / 4-1 / 2$ \\
\hline sand penstemon & Penstemon arenicola & $\mathrm{N}$ & sl & 24 & $1 / 4$ \\
\hline blue penstemon & Penstemon cyaneus & $\mathrm{N}$ & sil, sl & 28 & $1 / 4$ \\
\hline scabland penstemon & Penstemon deustus & $\mathrm{N}$ & sil & 24 & $1 / 4$ \\
\hline firecracker penstemon & Penstemon eatonii & $\mathrm{N}$ & sil, sl & 28 & $1 / 4$ \\
\hline Palmer’s penstemon & Penstemon palmeri & $\mathrm{N}$ & sil, l & 30 & $1 / 4$ \\
\hline Rydberg's penstemon & Penstemon rydbergii & $\mathrm{N}$ & sil & 32 & $1 / 4$ \\
\hline royal penstemon & Penstemon speciosus & $\mathrm{N}$ & sil & 36 & $1 / 4$ \\
\hline Rocky Mountain penstemon & Penstemon strictus & $\mathrm{N}$ & sil, l & 36 & $1 / 4$ \\
\hline Whipple’s penstemon & Penstemon whippleanus & $\mathrm{N}$ & sil & 24 & $1 / 4$ \\
\hline spiny phlox & Phlox hoodii & $\mathrm{N}$ & sil & 8 & $1 / 8$ \\
\hline longleaf phlox & Phlox longifolia & $\mathrm{N}$ & sil, sl, shallow & 20 & $1 / 8$ \\
\hline showy phlox & Phlox speciosa & $\mathrm{N}$ & sil, sl & 16 & $1 / 8$ \\
\hline blackeyed Susan & Rudbeckia hirta & $\mathrm{N}$ & sil, l & 24 & $1 / 4$ \\
\hline small burnet & Sanguisorba minor & I & sil, sl & 28 & $1 / 2$ \\
\hline scarlet globemallow & Sphaeralcea coccinea & $\mathrm{N}$ & sil & 10 & $1 / 4$ \\
\hline gooseberryleaf globemallow & Sphaeralcea grossulariifolia & $\mathrm{N}$ & sil, sl & 28 & $1 / 4$ \\
\hline Munro’s globemallow & Sphaeralcea munroana & $\mathrm{N}$ & sil, sl & 32 & $1 / 4$ \\
\hline Pacific aster & Symphyotrichum chilense & $\mathrm{N}$ & sl, sil, l & 36 & $1 / 4-1 / 2$ \\
\hline American vetch & Vicia americana & $\mathrm{N}$ & sil & 30 & $1 / 4$ \\
\hline winter vetch & Vicia villosa & I & sil, l & 30 & $1 / 4$ \\
\hline Mule’s-ears & Wyethia species & $\mathrm{N}$ & sil, cl & 36 & $1 / 2$ \\
\hline \multicolumn{6}{|c|}{ Shrubs } \\
\hline basin big sagebrush & Artemisia tridentata ssp. tridentata & $\mathrm{N}$ & sl, sil, l & 14 feet & $1 / 16$ feet \\
\hline mountain big sagebrush & Artemisia tridentata ssp. vaseyana & $\mathrm{N}$ & sil, cl, l & 9 feet & $1 / 16$ feet \\
\hline Wyoming big sagebrush & Artemisia tridentata ssp. wyomingensis & $\mathrm{N}$ & sl, sil, shallow & 3 feet & $1 / 16$ feet \\
\hline
\end{tabular}

Success of broadcast seeding is often hindered by a lack of seed-to-soil contact. To improve success, broadcast seeding can be combined with dragging harrows or chains across the seeded areas. Use caution with these techniques since they may lead to increased soil erosion if used on lands with erodible soils and they may decrease biological crusts where they occur and can break up the crowns of existing perennial herbaceous species. Livestock trampling after broadcast seeding also has been tried with inconsistent results. Research on timing and soil textures is likely necessary to improve information on these methods.

○ Transplants.

Stevens (2004) and Shaw (2004) provide the basis for much of the following discussion regarding transplanting as a tool for restoring arid and semiarid lands. Transplants may provide advantages over seedings in certain situations (Shaw, 2004), such as locations where (1) fast stabilization of soil is required but where seed drills may not be able to access, such as rocky sites, stream banks, or arroyo side slopes; (2) fast establishment is required for meeting wildlife habitat goals; (3) height and structure are required to create windbreaks to reduce wind erosion; (4) quick recovery of aesthetics are necessary; or (5) restoration species are difficult to establish from seeds. Transplants often require additional preplanting planning to have adequate stock available at the desired moment for planting. If planting into stands or patches of competitive annual grasses, it might be advantageous to apply an herbicide, such as imazapic, to the area or as a spot spray of the planting patch to release transplants from competition during the early establishment years. Use care with an herbicide or a rate of application that will harm the transplant. 
- Determine the type of transplant material. The options for transplant material depend on the species and propagation ease. Shaw (2004, see table 1) provides a table of species and propagation techniques that have been successful. There are four general types of transplanting material: container, bare root, wildlings, and vegetative propagation. Most container and bare root seedlings are initially sown with seeds. Stemcuttings also may be used for some woody species. Seeds may be available from seed merchants or may need to be collected depending on the species that you require. Generally, container or bare root plants are produced for species when seed germination techniques are known so that little research is necessary to provide adequate stocks for planting.

Container Plants. These will require more area in transport and preplanting handling facilities because containers must be spread out and maintained until planting occurs. Delivery should be scheduled to occur as close to the planting date as possible. Refrigerated trucks maintaining temperatures at slightly above freezing should be adequate. Environmental conditions after delivery of container plants are important for their survival. If containers are boxed, they should be moved to a large shaded and protected holding facility; such as, the north side of a building, a shaded lathhouse, or snowfenced area with shade cloth where seedlings can be watered and protected from animals may suffice. Once placed at the holding facility, plants will require watering and maintenance until planting. Dark containers should be shaded from sun to prevent high temperatures from affecting roots. Shading and cool temperatures should be maintained as long as possible at the field site until the seedling is ready for planting.

Bareroot Plants. Shaw (2004) references Dahlgreen (1976) for the critical factors that promote success of bareroot seedlings. Many of these factors relate to temperature and humidity from extraction until planting. Immediately after bareroot seedlings are removed from their growth medium, they should be packed and stored at temperatures near freezing and at high humidity to prevent desiccation. Refrigerated trucks or a snow cache (Dahlgreen and others, 1974) are recommended for transporting seedlings to sites. Before planting, seedlings should be gradually warmed, and kept moist, but not saturated in water to prevent an anaerobic environment. Dahlgreen (1976) recommends wrapping seedlings in burlap or a material that allows roots to breath, but maintaining high humidity by dipping wrapped seedlings in and out of water; then setting aside in a shaded location to acclimate to the lower of either the air or soil temperature $(8-10$ in. $[20-25 \mathrm{~cm}]$ depth).

Wildings. These are plants dug from a field location with field soil surrounding their roots. They can range from seedlings to mature plants. The larger the plant, the more extensive its root system that needs to be obtained. For species that have soil microbial associations (for example, mycorrhizal fungi), wildings will carry their associated microbes in the roots and soil.

Vegetative propagation. This is not a common technique used for sagebrush grassland ecosystems, but may be used in adjacent wet meadows or riparian areas. New individual plants arise from cuttings of mature plant stems, rhizomes, or stolons; and root production can be initiated through a number of techniques including, but not limited to, hormones, stem suckering, stem planting in moist soil, or crown division. Some species such as willows (Salix sp.) will root readily from stem cutting in moist soils, whereas upland species tend to be more problematic.

- Time required to obtain planting stock. This may range from months to years depending on the type of stock the project requires. There may be tradeoffs associated with the establishment success and the speed with which the species are placed in the ground, mature, and produce offspring. Shaw (2004) provides useful tables and figures for estimating the time required to produce adequate bare root or container seedlings for common species in the Intermountain West.

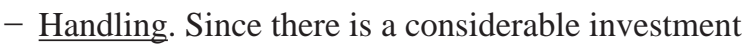
into the production of the planting stocks, it is good to follow some initial rules recommended by Stevens (2004, p. 739) to promote success. “(1) Never allow roots or stem ends to dry, (2) keep plants cool—do not allow them to overheat prior to planting, (3) plant during cool periods with adequate soil moisture, (4) compact soil around the roots at planting time, and (5) eliminate plant competition around the transplant."

- When to plant. Transplants need to be planted in late winter or early spring when soil moisture is high, wind is low, and temperatures are cold, but not likely to freeze and harm above ground plant tissues or result in frozen soils or frost heaving. As a guide, planting should occur just before plants growing 
within the region on similar sites would begin growth. Cool, overcast, windless, and humid days provide the best conditions for planting bare root or container stock. However, these conditions are difficult to find within the Intermountain West without the passage of a warm storm front that brings gentle warm rain to the area at the time of planting. Planting during sunny and windy days is potentially the most harmful toward transplant establishment due to high loss of water (transpiration) and poorly developed roots that cannot meet the water demands of the plants.

- How to plant. The most common approach used to plant seedlings on Intermountain West lands is to use manual planting of individual seedlings. Planting bare root or container seedlings requires attention to detail during plant handling, selection of locations to plant to reduce competition, proper hole construction, plant and root placement and soil tamping against roots. Diagrams of proper planting techniques are shown in Shaw (2004; figs. 15 and 16). Mechanical transplanters are available and can plant more transplants on landscapes where equipment can be used (http:// reveg-catalog.tamu.edu/10-Specialized\%20Planters. htm, accessed December 27, 2016)

- Number of plants and spacing among plants. Determine the area (A) in square feet $\left(\mathrm{ft}^{2}\right)$ or meters $\left(\mathrm{m}^{2}\right)\left(43,560 \mathrm{ft}^{2}=1\right.$ acre; $\left.1000 \mathrm{~m}^{2}=1 \mathrm{ha}\right)$ that will be planted. Next, determine the distance (D) in $\mathrm{ft}(\mathrm{m})$ between plant centers (from center to center of each plant) for each transplant. Assuming a square planting pattern, the number of plants $(\mathrm{N})$ will equal the area divided by the square of the distance between plants: $\mathrm{N}=\mathrm{A} / \mathrm{D}^{2}$. For example, typical sagebrush spacing for Wyoming big sagebrush (Artemisia tridentata ssp. wyomingensis) in the Great Basin is between 3.5 and $4.0 \mathrm{ft}$ (1.07 and $1.25 \mathrm{~m} ; \mathrm{D})$. Dense stands are less than $2.0 \mathrm{ft}(0.61 \mathrm{~m})$ between plants with sparse stands being greater than $7.0 \mathrm{ft}(2.13 \mathrm{~m})$ between plant centers.

So, for U.S. customary units, to plant 100 acres: $\mathrm{A}=100$ acres $\times 43,560 \mathrm{ft}^{2} / \mathrm{acre}=435,600 \mathrm{ft}^{2}$; then $\mathrm{N}=\mathrm{A} / \mathrm{D}^{2}=435,600 \mathrm{ft}^{2} /(3.5 \mathrm{ft} / \mathrm{plant})^{2}=435,600 / 12.25$ $\mathrm{ft}^{2} /$ plant $=35,559$ plants for 100 acres planted at 3.5-ft centers.

For metric units, the example is for 100 ha: A $=100$ ha $\times 10,000 \mathrm{~m}^{2}=100,000 \mathrm{~m}^{2}$; then $\mathrm{N}=\mathrm{A} /$ $\mathrm{D}^{2} 100,000 \mathrm{~m}^{2} /(1.07 \mathrm{~m} / \mathrm{plant})^{2}=100,000 / 1.1449$ $\mathrm{m}^{2}=114,490$ plants for 100 ha planted at $1.06-\mathrm{m}$ centers.

\section{Step 7. Post-Treatment Grazing Management}

Large animals may impact vegetation recovery after disturbances like fire and after revegetation treatments, thus deferment of grazing may be instituted to allow adequate establishment, recovery, or both. These disturbances should be treated differently since revegetation often depends on the establishment of seeded or planted individuals, whereas recovery after fire relies on regrowth of surviving adult plants and the pre-fire plant community composition. Recovery after fire may require only the recovery of the existing plants, or it may require colonization of patches previously occupied by fire sensitive plants. Colonization is done through either seed production, germination and establishment of new seedlings, or through vegetative expansion of surviving plants through root growth, stolons, or rhizomes.

\section{- What animals currently use the area?}

Consider small animals, especially ground squirrels and rabbits along with livestock, horses, burros, and ungulate wildlife. Small animal populations may cycle, and alternative measures to combat their impacts could be considered. Weigh any animal reductions against those animal conservation benefits for the ecosystem and against the time necessary for those animals to recover from reductions.

\section{- Deferment of Animal Use.}

Deferment of animal use can depend on several criteria including, but not limited to, the ecological site (sites resistance and resilience), the type of disturbance, posttreatment weather, post-treatment fuel loads, and the restoration species. Research publications lack detailed studies and produced mixed results across multiple sites making it difficult to draw general conclusions (Jirik and Bunting, 1994; Bunting and others, 1998; Bates and others, 2009; Roselle and others, 2010). After fires, generally defoliation of surviving perennial grasses during the first active growing season after the fire is harmful to grass growth and reproduction. Dormant-season grazing appears to have the least impact on the perennial grasses surviving after fires, but if the area is sage-grouse habitat, dormant-season grazing will reduce hiding cover and grass heights temporarily; and managers should be aware of this potential impact. Impacts of unmanaged or difficult to manage populations (for example, wild horses or burros) should be considered in conjunction with domestic livestock impacts during planning and evaluation. 
○ Length of deferment.

The time of deferment for livestock use is difficult to estimate since this may depend on the level of revegetation success or recovery and on environmental conditions including weather and herbivory outside of the manager's control (for example, insects, rodents, or rabbits). Setting trigger objectives for the resumption of grazing is an acceptable alternative to setting hard timelines. Since project objectives may be met while the ecosystem is recovering (as opposed to recovered), grazing may be resumed before full ecosystem recovery is realized (but after deferment objectives have been met). To avoid negative impacts, acceptable grazing practices and monitoring thresholds beyond the project timeline may be described to support adaptation of grazing practices to changing conditions in the project area.

- Objectives. Since a major objective in many revegetation projects is to achieve adequate densities of perennial grasses to resist invasions of invasive annual grasses, an achievable objective is a density of 2.15-3.23 deep-rooted perennial grasses per $10 \mathrm{ft}^{2}$ (2-3 grasses per $\mathrm{m}^{2}$ ). The less resilient and resistant (warmer and drier) the site, the density objective should be set closer to the 3.23 grasses per $10 \mathrm{ft}^{2}$ (3 grasses per $\mathrm{m}^{2}$ ). Another objective is to allow all grasses to become reproductive and to have adequate roots to withstand being pulled from the ground. Some revegetation projects are setting an average basal diameter of $3 \mathrm{in}$. $(7.62 \mathrm{~cm})$ for bunchgrasses to allow adequate root growth and spread from the parent plant. Another potential trigger for allowing periodic grazing may focus on fuel loads and fuel continuity, especially in warm-dry areas where invasive annual grasses may dominate. When these triggers are met, livestock grazing may be resumed. Additional monitoring of grazing effects, such as cover or basal area, to determine whether additional thresholds are crossed, may institute additional grazing rest or other grazing regime adjustments to sustain the trajectory of restoration until "full ecosystem recovery” has been reached.

- Suggested deferments based on expert opinions. Stevens (2004) included three tables to assist managers in considering deferments depending on vegetation type (table 12), site disturbance severity (table 13), and the establishment species (table 14).

Table 12. Recommended minimum number of growing seasons to defer defoliation to achieve restoration objectives.

[Based on Stevens, 2004. A bbreviations: in., inch; cm, centimeter]

\begin{tabular}{|c|c|c|}
\hline Vegetation type & $\begin{array}{l}\text { Long-term average } \\
\text { annual precipitation }\end{array}$ & $\begin{array}{l}\text { Recommended growing } \\
\text { seasons with no } \\
\text { grazing following seeding }\end{array}$ \\
\hline mountain brush & All & 2 \\
\hline $\begin{array}{l}\text { juniper (Juniperus sp.) and/or } \\
\text { piñon (Pinus edulis) }\end{array}$ & Greater than 14 in. $(36 \mathrm{~cm})$ & 2 \\
\hline $\begin{array}{l}\text { juniper (Juniperus sp.) and/or } \\
\text { piñon (Pinus edulis) }\end{array}$ & Less than or equal to 14 in. $(36 \mathrm{~cm})$ & 3 \\
\hline $\begin{array}{l}\text { mountain big sagebrush } \\
\text { (Artemisia tridentata ssp. vaseyana) }\end{array}$ & All & 2 \\
\hline $\begin{array}{l}\text { basin big sagebrush } \\
\text { (Artemisia tridentata ssp. tridentata) }\end{array}$ & Greater than 14 in. $(36 \mathrm{~cm})$ & 2 \\
\hline $\begin{array}{l}\text { basin big sagebrush } \\
\text { (Artemisia tridentata ssp. tridentata) }\end{array}$ & Less than or equal to 14 in. $(36 \mathrm{~cm})$ & 3 \\
\hline $\begin{array}{l}\text { Wyoming big sagebrush } \\
\text { (Artemisia tridentata ssp. wyomingensis) }\end{array}$ & Greater than 12 in. $(30 \mathrm{~cm})$ & 3 \\
\hline $\begin{array}{l}\text { Wyoming big sagebrush } \\
\text { (Artemisia tridentata ssp. wyomingensis) }\end{array}$ & Less than or equal to 12 in. $(30 \mathrm{~cm})$ & 4 \\
\hline $\begin{array}{l}\text { black sagebrush } \\
\text { (Artemisia nova) }\end{array}$ & All & 3 \\
\hline
\end{tabular}


Table 13. Additional years of deferment of large animal herbivory beyond those cited in table 12.

[From Stevens, 2004. Abbreviations: in., inch; cm, centimeter]

\begin{tabular}{|l|c|}
\hline \multicolumn{1}{|c|}{ Site conditions } & $\begin{array}{c}\text { Recommended additional growing seasons with no } \\
\text { grazing following seeding to add to the vegetation } \\
\text { type recommendation (table 12) }\end{array}$ \\
\hline Burned and broadcast seeded & 1 \\
\hline Slower growing shrubs seeded or released & $2-4$ \\
\hline $\begin{array}{l}\text { Seedings that are competing with invasive grasses [for example, cheatgrass (Bromus } \\
\text { tectorum), red brome (Bromus rubens), field brome (Bromus arvensis), medusahead } \\
\text { (Taniatherum caput-medusae), and North Africa grass (Ventenata dubia)] }\end{array}$ & $1-3$ \\
\hline Poor seedbed conditions & \\
\hline Erosive soils & 1 \\
\hline $\begin{array}{l}\text { Precipitation below long-term average by greater than or equal to } 2 \text { in. }(5 \mathrm{~cm}) \text { during } \\
\text { any of the first year of seedling growth }\end{array}$ & $1-3$ \\
\hline $\begin{array}{l}\text { Precipitation below long-term average by greater than or equal to } 2 \text { in. }(5 \mathrm{~cm}) \text { during } \\
\text { any of the second or third year of seedling growth }\end{array}$ & $1-3$ \\
\hline Outbreak of herbivorous insects & 1 \\
\hline High population levels of rodents or rabbits during the first 3 years of growth & $1-3$ \\
\hline
\end{tabular}

Table 14. Years normally required to establish, mature, and flower provided these plants are not defoliated.

[From Stevens, 2004]

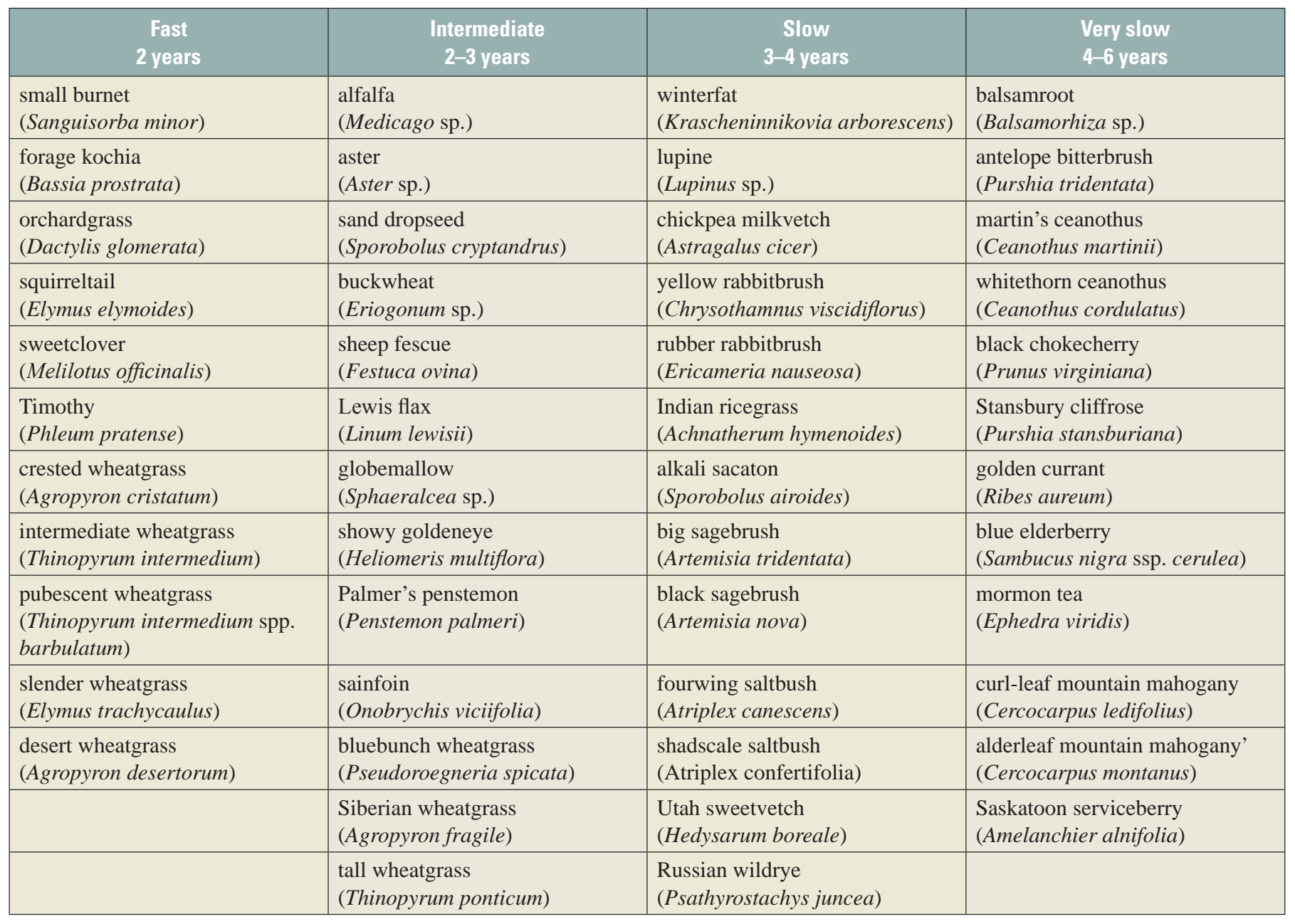




\section{Step 8. Implementation and Effectiveness Monitoring}

Implementation and effectiveness are two phases of monitoring that provide managers with documentation as to (1) when and what components of the restoration were accomplished relative to the plan and schedule (implementation) contrasted with (2) how well the restoration project met the stated quantitative objectives of the project (effectiveness).

\section{- Implementation Monitoring.}

Implementation monitoring tracks whether each stage in the restoration plan was completed as planned and documents any deviations from planned implementation (for example, modifications in seed mixture or time of planting). If modifications were necessary, the implementation monitoring should capture these changes. Most of this phase of monitoring can be accomplished through a checklist with a column for Proposed Implementation Date; a second column indicating when implementation occurred; and a third column for notes to allow users to enter potential impacts of delayed implementation (table 15). Photographs taken at the implementation stages are also valuable in interpreting results in the future. An often overlooked, but extremely important part of the implementation monitoring is tracking the final seed purchase, the purity data, the provenance information where the plant material came from (if available), and where plant material was sown on the project since these may assist in determining why objectives were not met during effectiveness monitoring. If this seed information is not confirmed through documentation, effectiveness monitoring can be affected in two ways. First, evaluators may search for species that were not sown. Second, evaluators may detect seedling species that were not listed as having been sown, when in fact they were. Both of these potential errors would result in inaccurate results and could impact later decisions pertaining to adaptive management of restoration in the future.

\section{- Effectiveness Monitoring.}

Monitoring the effectiveness of restoration treatments requires the collection of data to estimate whether the project quantitative objectives were met by the restoration treatment that was imposed. Many publications are written on monitoring. We refer readers to Elzinga and others (1998) and Herrick and others (2009) for instructions that guide the user through the process of establishing all aspects of effectiveness monitoring. We also suggest the use of computer tablet data entry software [for example, Database for Inventory Monitoring and Assessment (DIMA) http://jornada.nmsu.edu/monit-assess/dima, accessed December 27, 2016) that allow data storage in a database for future access. Here we briefly touch on the major elements that follow the defined objectives listed in the first section of this of this guide (Step 1. What are Site-specific Management and Sampling Objectives for Restoration?).

- Stratify the restoration project into monitoring units.

Monitoring units are areas with similar site characteristic (soil map units and ecological sites) and disturbance histories (for example, similar grazing management). Differences among site characteristics or disturbances and differences among treatment methods may invoke a new monitoring unit (for example, figure 2).

- Define the sampling unit.

Sample units are often areas of single or sets of plots, transects, or individual plants within the monitoring unit in which variables related to the quantitative objectives are measured (for example, Controls or Treatment Plots in figure 2). There are generally multiple plot areas that are randomly located within the monitoring unit and the total number of sample units provide the sample size over which estimates of central tendency (mean) and variation of the population are derived.

- Determine the variable to be measured in the sampling unit.

This relates directly to the variable listed in the quantitative objective. One or more measurements directly related to the objective should be recorded. Multiple objectives can be informed with each sampling event (visit to a sample unit) by creating a protocol which includes multiple measurements or the same measurement can address multiple objectives.

- Determine the number of sampling units, their locations, and the frequency of sampling.

You need at least three sampling units to make an initial estimate of the variation around a mean value. Generally, locations of the sample units are placed randomly within the monitoring unit. The frequency of sampling through time also requires a minimum of two time periods to determine an initial trend, but more samples over time will better determine the consistency of the trend.

- Determine the baseline for monitoring.

This can be viewed as the initial monitoring data.

$\circ$ Repeat monitoring for trend.

Repeat at multiple time intervals until the objective is achieved or until sufficient repeated monitoring can provide a trend that could be used to modify the timeframe indicated in the initial objective. 
Table 15. Example of the elements necessary for an implementation monitoring checklist.

\begin{tabular}{|l|l|l|l|}
\hline \multicolumn{1}{|c|}{ Activity } & \multicolumn{1}{|c|}{$\begin{array}{c}\text { Proposed date } \\
\text { Implementation date }\end{array}$} & \multicolumn{1}{c|}{$\begin{array}{c}\text { Reason for deviation between } \\
\text { proposed and implemented dates }\end{array}$} \\
\hline Herbicide application & November 1-15, 2015 & October 25, 2015 & Adequate precipitation occurred early \\
\hline Seeding & November 15-30, 2015 & February 15, 2016 & Snow and frozen soil by late November \\
\hline Transplanting & October 15-30, 2016 & October 20, 2016 & None \\
\hline
\end{tabular}

○ Compare to the monitoring objective and determine whether objective was met.

You can use statistical methods to determine whether the objective was met. A visual evaluation of data by comparing the mean and confidence interval is an easy approach (fig. 3). A spreadsheet with this graphical approach is available at http://fresc.usgs.gov/sites/ ESRMonitoring/Tools.htm (accessed December 27, 2016). Although some information may be gleaned from individual sample units (such as, recognizing areas with aberrant conditions), data should be evaluated collectively by treating sample units as replicates with summary statistics calculated across the project area, or ecological sites defined in the monitoring design.

\section{- Databases}

Data, analyses, and reports are best preserved if stored in an archival database along with the objectives, implementation monitoring information, and the final report of findings. Examples can be accessed in the Land Treatment Digital Library (LTDL) at https://tdl.wr.usgs. gov/ (accessed December 27, 2016).

- Compare among multiple projects using the same treatments to determine the consistency of the results

Adding ancillary information relating to other projects (for example, elevation and precipitation) may aid in understanding where objectives are met and where they are not.

\section{Step 9. Adaptive Management}

Are there adjustments to the restoration project that might increase the effectiveness of future projects? There are a number of definitions for adaptive management, but the one we feel best displays the intent that allows for flexible management adjustments over time was provided by The National Research Council (2004, p. 1-2):

"Adaptive management promotes flexible decision making that can be adjusted in the face of uncertainties as outcomes from management actions and other events become better understood. Careful monitoring of these outcomes both advances scientific understanding and helps adjust policies or operations as part of an iterative learning process. Adaptive management also recognizes the importance of natural variability in contributing to ecological resilience and productivity. It is not a 'trial and error' process, but rather emphasizes learning while doing. Adaptive management does not represent an end in itself, but rather a means to more effective decisions and enhanced benefits. Its true measure is in how well it helps meet environmental, social, and economic goals, increases scientific knowledge, and reduces tensions among stakeholders.”

Adaptive management depends on explicit objectives with expected outcomes for comparison to actual outcomes. Since we begin with quantifiable objectives and timeframes for our restoration treatments (see section, Step 1. What are Site-specific Management and Sampling Objectives for Restoration?), we can monitor and determine if, when, and where our objectives were achieved. Stating alternative management outcomes may aid in selecting potential adjustments in management or restoration techniques. Restoration alternatives may be applied in a single location (for example, multiple treatments within a location or project area) or spread over several projects within a region (for example, different individual treatments applied across several projects within a region) (fig. 4). Effectiveness of treatments in achieving objectives over several locations may help future restoration decisions or post-restoration management plans. 


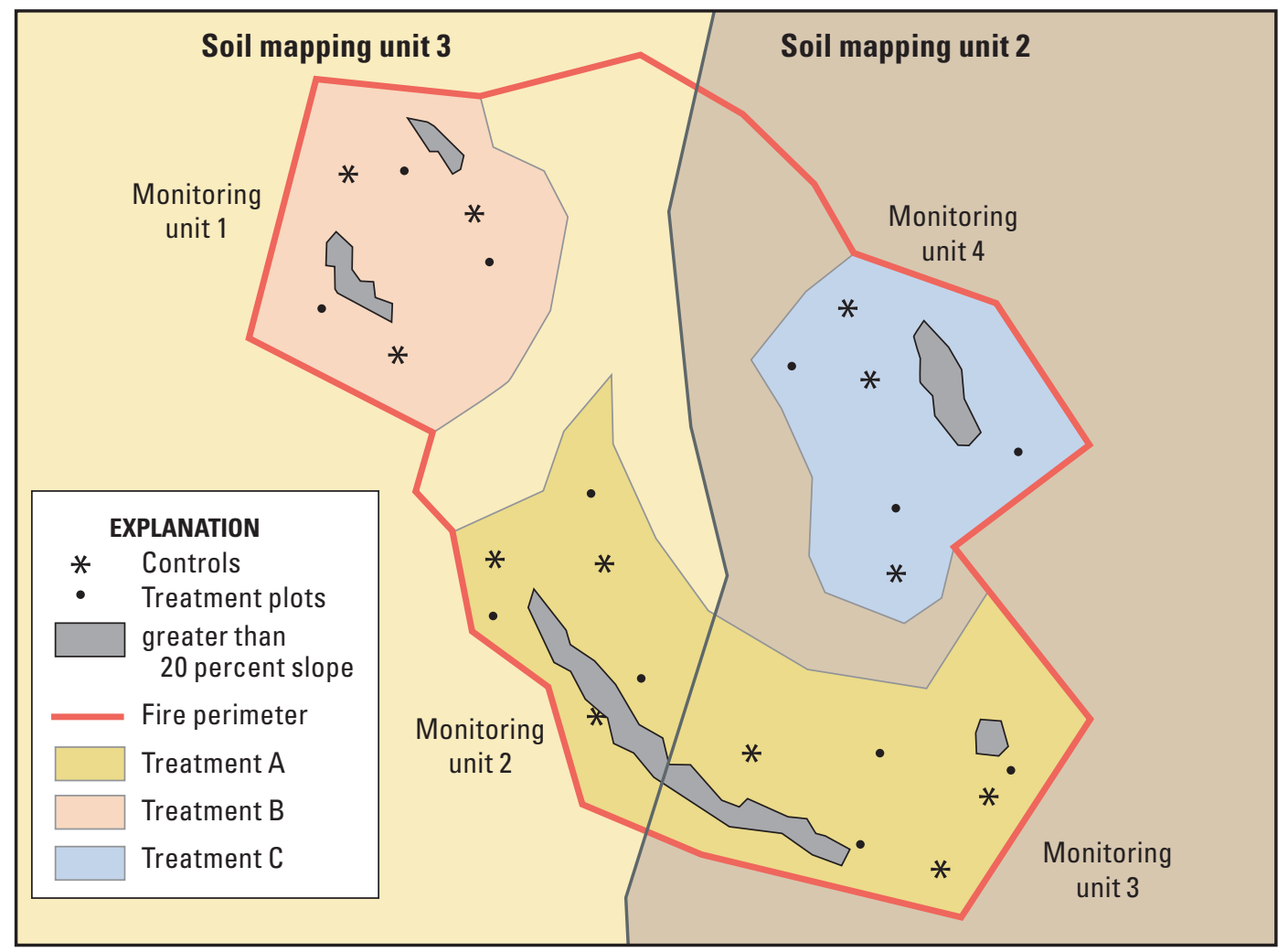

Figure 2. Hypothetical monitoring situation with three treatments and four monitoring units. Monitoring unit 1 consists of treatment $B$ within soil mapping unit 3. Monitoring unit 2 consists of treatment $A$ within soil mapping unit 3 . Monitoring unit 3 consists of treatment $A$ within soil mapping unit 2. Monitoring unit 4 consists of treatment $\mathrm{C}$ within soil mapping unit 2 (After Wirth and Pyke, 2007).

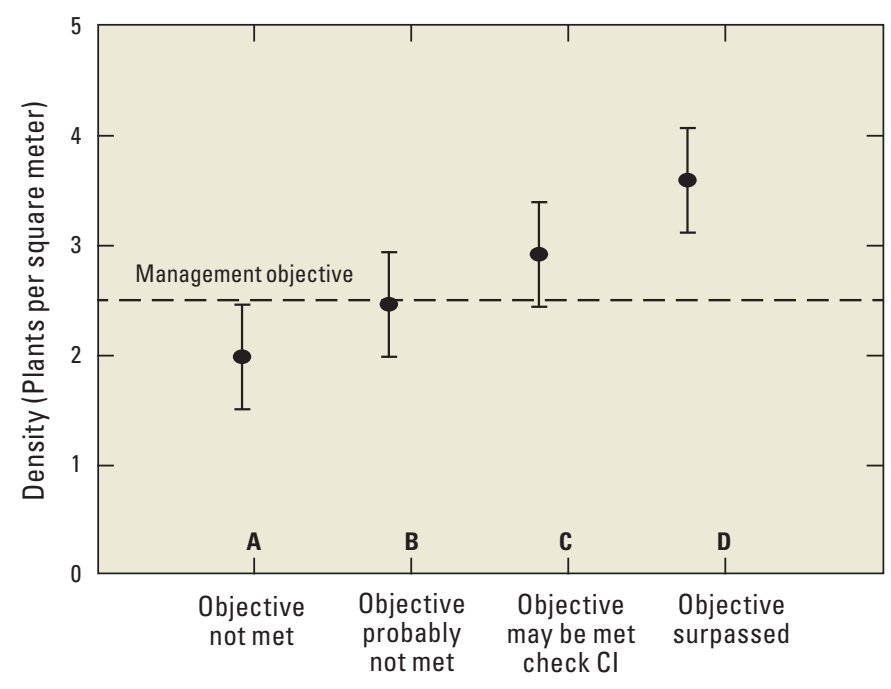

Figure 3. Mean plant density (filled circle) and 95 percent confidence interval around the mean relative to a set management objective (dashed line). Possible outcomes when comparing treatments to quantitative objectives. Means and 1- $\alpha$ confidence intervals are shown. (A) objective not met, $(B)$ objective probably not met (evaluate precision and consider additional sampling), (C) objective may be met, check confidence interval (CI), and (D) objective surpassed.
Knutson and others (2014) provided another example where they gathered weather and topographic information to help in determining conditions that led to successful restoration. Certainty of successfully achieving restoration objectives increased with elevation or precipitation, but this certainty of success changed with restoration treatment (aerial as opposed to drill seeding) and with type of vegetation (perennial grasses and shrubs). As uncertainty increases, our ability to control aspects of restoration treatments (for example, seeding methods and species selections) lend best to adaptive management decisions assisting in determining appropriate actions (Williams and others, 2009). In sagebrush steppe ecosystems, locations with low resistance and resilience (warm and dry soil temperature and moisture regimes) may benefit more from adaptive management approaches than locations with high resistance and resilience. 
A simple example of an adaptive management restoration project in a warm and dry sagebrush steppe location might include a drill seeding in combination with alternative methods for controlling cheatgrass. Areas with similar ecological sites could be treated with four alternatives for controlling cheatgrass: (1) an application of imazapic herbicide; (2) a bacterial application of Pseudomonas fluorescens, Strain D7 (D7); (3) a combination of the imazapic and D7; or (4) no control treatment. Since bacterial applications may require 3 years to control cheatgrass, comparisons of cover of cheatgrass among treatments might be done in years 4-6 post-treatment. In addition, measurements of the cover of seeded species would be tracked annually from year 2 onward. Consistent results from multiple locations where these alternatives were applied may provide information on best treatments for controlling cheatgrass and establishment of perennial species for future restoration efforts in warm and dry environments.

\section{Acknowledgments}

This is Contribution Number 105 of the Sagebrush Steppe Treatment Evaluation Project (SageSTEP), funded by the U.S. Joint Fire Science Program (05-S-08), the National Interagency Fire Center, the Bureau of Land Management, the Great Northern Land Conservation Cooperative, and the U.S. Geological Survey. Additional funding was provided by the Western Association of Fish and Wildlife Agencies (WAFWA) through an agreement with Pheasants Forever and the Intermountain West Joint Venture under the Sage-Grouse Initiative Strategic Watershed Action Team (SGI SWAT). We thank members of the WAFWA Sage and Columbia Sharptail Grouse Technical Committee for their guidance and input on this project. We thank L. Gilbert, S. Beldin and two anonymous people for reviews and input that improved this handbook.

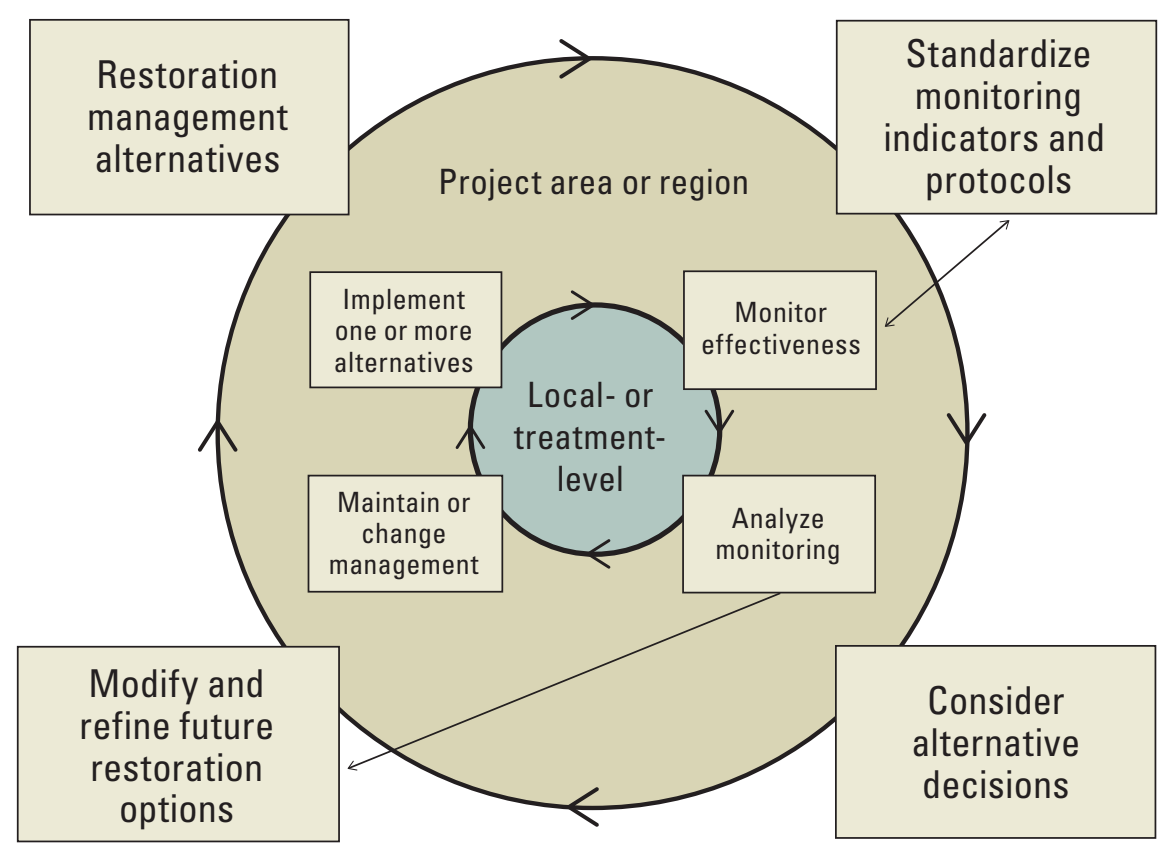

Figure 4. Simplified adaptive management for restoration decisions. The outer circle describes region- or project-wide stages (within which local- or treatment-level decisions) that may be conducted multiple times with alternative restoration methods or management options. 


\section{References Cited}

Bainbridge, D.A., 2007, A guide for desert and dryland restoration—New hope for arid lands: Washington, D.C., Island Press.

Baker, W.L., 2013, Is wildland fire increasing in sagebrush landscapes of the Western United States?: Annals of the Association of American Geographers, v. 103, p. 5-19.

Bates, J.D., Rhodes, E.C., Davies, K.W., and Sharp, R., 2009, Postfire succession in big sagebrush steppe with livestock grazing: Rangeland Ecology and Management, v. 62, p. 98-110.

Benson, J.E., Tveten, R.T., Asher, M.G., and Dunwiddie, P.W., 2011, Shrub-steppe and grassland restoration manual for the Columbia River Basin: Olympia, Washington Department of Fish and Wildlife, WDFW01330, accessed October 20, 2016, at http://wdfw.wa.gov/publications/01330/ wdfw01330.pdf.

Beyers, J.L., 2004, Postfire seeding for erosion controlEffectiveness and impacts on native plant communities: Conservation Biology, v. 18, p. 947-956.

Bradford, J.B., and Lauenroth, W.K., 2006. Controls over invasion of Bromus tectorum-The importance of climate, soil, disturbance and seed availability: Journal of Vegetation Science, v. 17, p. 693-704.

Bradley, B.A., 2009, Regional analysis of the impacts of climate change on cheatgrass invasion shows potential risk and opportunity: Global Change Biology, v. 15, p. 196-208.

Bunting, S.C., Robberrecht, R., and Defossé, G.E., 1998, Length and timing of grazing on postburn productivity of two bunchgrasses in an Idaho experimental range: International Journal of Wildland Fire, v. 8, p. 15-20.

Bureau of Land Management, 2015a, Record of decision and approved resource management plan amendments for the Great Basin region, including the greater sage-grouse sub-regions of Idaho and southwestern Montana; Nevada and northeastern California; Oregon; and Utah: Bureau of Land Management, accessed October 20, 2016, at http:// www.blm.gov/style/medialib/blm/wo/Communications_ Directorate/public_affairs/sage-grouse_planning/documents. Par.44118.File.dat/GB\%20ROD.pdf.
Bureau of Land Management, 2015b, Record of decision and approved resource management plan amendments for the Rocky Mountain region, including the greater sage-grouse sub-regions of Lewistown, North Dakota, northwest Colorado, Wyoming, and the approved resource management plans for Billings, Buffalo, Cody, HiLine, Miles City, Pompeys Pillar National Monument, South Dakota, Worland: Bureau of Land Management, accessed October 20, 2016, at http://www.blm.gov/style/medialib/ blm/wo/Communications_Directorate/public_affairs/sagegrouse_planning/documents.Par.57493.File.dat/RM\%20 ROD.pdf.

Dahlgreen, A.K., 1976, Care of forest tree seedlings from nursery to planting hole, in Baumgartner, D.M., and Boyd, R.J., eds., Tree planting in the inland Northwest-Short course proceedings held at Washington State University, Pullman, February 17-19, 1976: Pullman, Washington State University, Cooperative Extension Service, p. 205-238.

Dahlgreen, A.K., Ryker, R.A., and Johnson, D.L., 1974, Snow cache seedling storage-Successful systems: U.S. Forest Service, Intermountain Forest and Range Experiment Station, Ogden, Utah, General Technical Report INT-17.

Elzinga, C.L., Salzer, D.W., and Willoughby, J.W., 1998, Measuring and monitoring plant populations: Bureau of Land Management Technical Reference 1730-1, BLM/RS/ ST-98/005+1730, accessed October 20, 2016, at http://www. blm.gov/nstc/library/pdf/MeasAndMon.pdf.

Fleming, J., 2005, Vehicle cleaning technology for controlling the spread of noxious weeds and invasive species: U.S. Forest Service, San Dimas Technology and Development Center, California, 0551-1203 SDTDC.

Hardegree, S.P., Schneider, J.M., and Moffet, C.A., 2012, Weather variability and adaptive management for rangeland restoration: Rangelands, v. 34, p. 53-56.

Hardegree, S.P., Sheley, R.L., Duke, S.E., James, J.J., Boehm, A.R., and Flerchinger, G., 2016, Temporal variability in microclimatic conditions for grass germination and emergence in the sagebrush steppe: Rangeland Ecology and Management, v. 69, p. 123-128.

Herrick, J.E., Van Zee, J.W., Havstad, K.M., Burkett, L.M., and Whitford W.G., 2009, Monitoring manual for grassland, shrubland and savanna ecosystems: U.S. Department of Agriculture, Agricultural Research Service, Jornada Experimental Range, Las Cruces, New Mexico. 
Heyerdahl, E.K., Miller, R.F., and Parsons, R.A., 2006, History of fire and Douglas-fir establishment in a savanna and sagebrush-grassland mosaic, southwestern Montana, USA: Forest Ecology and Management, v. 230, p. 107-118.

Jirik, S.J., and Bunting, S.C., 1994, Post-fire defoliation response of Agropyron spicatum and Sitanion hystrix: International Journal of Wildland Fire, v. 42, p. 77-82.

Jones, R.O., Chambers, J.C., Board, D.I., Johnson, D.W., and Blank, R.R., 2015, The role of resource limitation in restoration of sagebrush ecosystems dominated by cheatgrass (Bromus tectorum): Ecosphere v. 6, no. 107, p. 1-21, DOI: 10.1890/ES14-00285.1.

Jorgensen, K.R., and Stevens, R., 2004, Seed collection, cleaning, and storage, chap. 24 of Monsen, S.B., Stevens, Richard, Shaw, N.L., compilers, Restoring western ranges and wildlands, volume 3: U.S. Forest Service, Rocky Mountain Research Station, Fort Collins, Colorado, General Technical Report RMRS-GTR-136-vol-3, p. 699-716.

Knutson, K.C., Pyke, D.A., Wirth, T.A., Arkle, R.S., Pilliod, D.S., Brooks, M.L., Chambers, J.C., and Grace, J.B., 2014, Long-term effects of seeding after wildfire on vegetation in Great Basin shrubland ecosystems: Journal of Applied Ecology, v. 51, p. 1,414-1,424.

Lambert, S., 2005, Guidebook to the seeds of native and nonnative grasses, forbs and shrubs of the Great Basin: Bureau of Land Management, Idaho State Office, Boise, Idaho BLM Technical Bulletin 2005-04.

McDaniel, K.C., and Balliette, J.F., 1986, Control of big sagebrush (Artemisia tridentata) with pelleted tebuthiuron: Weed Science, v. 34, p. 276-280.

Mealor, B.A., Mealor, R.D., Kelley, W.K., Bergman, D.L., Burnett, S.A., Decker, T.W., Fowers, B., Herget, M.E., Noseworthy, C.E., Richards, J.L., Brown, C.S., Beck, K.G., and Fernandez-Gimenez, M., 2013, Cheatgrass management handbook-Managing an invasive annual grass in the Rocky Mountain region: Laramie, University of Wyoming Extension Bulletin B-1246, 131 p.

Miller, R.F., Chambers, J.C., and Pellant, M., 2014, A field guide for selecting the most appropriate treatment in sagebrush and piñon-juniper ecosystems in the Great Basin-Evaluating resilience to disturbance and resistance to invasive annual grasses, and predicting vegetation response: U.S. Forest Service, Rocky Mountain Research Station, Fort Collins, Colorado, General Technical Report RMRS-GTR-322.
Miller, R.F., Chambers, J.C., Pyke, D.A., Pierson, F.B., and Williams C.J., 2013, A review of fire effects on vegetation and soils in the Great Basin region-Response and ecological site characteristics: U.S. Forest Service, Rocky Mountain Research Station, Fort Collins, Colorado, General Technical Report RMRS-GTR-308.

Miller, R.F., Knick, S.T., Pyke, D.A., Meinke, C.W., Hanser, S.E., Wisdom, M.J., and Hild, A.L., 2011, Characteristics of sagebrush habitats and limitations to long-term conservation, in Knick, S.T., and Connelly, J.W., eds., Greater sage-grouse-Ecology and conservation of a landscape species and its habitats: Berkeley, University of California Press, Studies in Avian Biology (volume 38), p. 145-184.

Miller, R.F., Svejcar, T.J., and Rose, J.A., 2000, Impacts of western juniper on plant community composition and structure: Journal of Range Management, v. 53, p. 574-585.

Monsen, S.B., and Stevens, R., 2004, Seedbed preparation and seeding practices, in Monsen, S.B., Stevens, R., and Shaw, N.L., compilers, Restoring western ranges and wildlands: U.S. Forest Service, Rocky Mountain Research Station, Fort Collins, Colorado, General Technical Report RMRS-GTR136-vol-1, p. 121-154.

Munson, S.M., Long, A.L., Decker, C., Johnson, K.A., Walsh, K., and Miller, M.E., 2015, Repeated landscape-scale treatments following fire suppress a non-native annual grass and promote recovery of native perennial vegetation: Biological Invasions, v. 17, p. 1,915-1,926.

National Research Council, 2004, Adaptive management for water resources planning: Washington, D.C., The National Academies Press.

Ott, J.E., Cox, R.D., Shaw, N.L., Newingham, B.A., Ganguli, A.C., Pellant, M., Roundy, B.A., and Eggett, D.L., 2016, Postfire drill-seeding of Great Basin plants - Effects of contrasting drills on seeded and nonseeded species: Rangeland Ecology \& Management, v. 69, p. 373-385.

Ott, J., Halford, A., and Shaw, N., 2016, Seeding techniques for sagebrush community restoration after fire: Reno, Nevada, Great Basin Fire Science Exchange, Fact Sheet 14, accessed October 20, 2016, at http://greatbasinfirescience. org/research-publications/2016/4/1/seeding-techniques-forsagebrush-community-restoration-after-fire.

Pellant, M., Shaver, P., Pyke, D.A., and Herrick, J.E., 2005, Interpreting indicators of rangeland health, version 4: Bureau of Land Management, National Science and Technology Center, Denver, Colorado, Technical Reference 1734-6, BLM/WO/ST-00/001+1734/REV05. 
Plant Conservation Alliance, 2015, National seed strategy for rehabilitation and restoration 2015-2020: Washington, D.C., Bureau of Land Management, BLM/WO/GI-15/012+7400, 50 p.

Pyke, D.A., Brooks, M.L., and D’Antonio, C., 2010, Fire as a restoration tool-A decision framework for predicting the control or enhancement of plants using fire: Restoration Ecology, v. 18, p. 274-284.

Pyke, D.A., Chambers, J.C., Pellant, M., Knick, S.T., Miller, R.F., Beck, J.L., Doescher, P.S., Schupp, E.W., Roundy, B.A., Brunson, M., and McIver, J.D., 2015, Restoration handbook for sagebrush steppe ecosystems with emphasis on greater sage-grouse habitat-Part 1, Concepts for understanding and applying restoration: U.S. Geological Survey Circular 1416, http://dx.doi.org/10.3133/cir1416.

Pyke, D.A., Knick, S.T., Chambers, J.C., Pellant, M., Miller, R.F., Beck, J.L., Doescher, P.S., Schupp, E.W., Roundy, B.A., Brunson, M., and McIver, J.D., 2015, Restoration handbook for sagebrush steppe ecosystems with emphasis on greater sage-grouse habitat-Part 2, Landscape level restoration decisions: U.S. Geological Survey Circular 1418, http://dx.doi.org/10.3133/cir1418.

Robichaud, P.R., Ashmun, L.E., and Sims, B.D., 2010, Postfire treatment effectiveness for hillslope stabilization:. U.S. Forest Service, Rocky Mountain Research Station, Fort Collins, Colorado, General Technical Report RMRSGTR-240.

Robichaud, P.R., Beyers, J.L., and Neary, D.G., 2000, Evaluating the effectiveness of postfire rehabilitation treatments: U.S. Forest Service, Rocky Mountain Research Station, Fort Collins, Colorado, General Technical Report RMRS-GTR-63.

Roselle, L., Seefeldt, S.S., and Launchbaugh, K., 2010, Delaying sheep grazing after wildfire in sagebrush steppe may not affect vegetation recovery: International Journal of Wildland Fire, v. 19, p. 115-122.

Roundy, B.A., Young, K., Cline, N., Hulet, A., Miller, R.F., Tausch, R.J., Chambers, J.C., and Rau, B., 2014, Piñon-juniper reduction increases soil water availability of the resource growth pool: Rangeland Ecology and Management, v. 67, p. 495-505.
St. John, L., Tilley, D. Scianna, J., Jacobs, J. Ogle, D., Majerus, M., and Holzworth, L., 2012, Mixing seed with rice hulls: Natural Resources Conservation Service Boise Idaho, Technical Note 7 (revised), 16 p.

Sankey, J.B., Germino, M.J., Benner, S.G., Glenn, N.F., and Hoover, A.N., 2012, Transport of biologically important nutrients by wind in an eroding cold desert: Aeolian Research, v. 7, p. 17-27.

Shaw, N.L., 2004, Production and use of planting stock, in Monsen, S.B., Stevens, R., and Shaw, N.L., compilers, Restoring western ranges and wildlands: U.S. Forest Service, Rocky Mountain Research Station, Fort Collins, Colorado, General Technical Report RMRS-GTR-136vol-3, p. 745-768.

Smith, B., Sheley, R., and Svejcar, T., 2012, Grazing invasive annual grasses - The green and brown guide: Corvallis, U.S. Department of Agriculture Agricultural Research Service and Oregon State University, Eastern Oregon Experiment Station, Publication 724.

Stevens, R., 2004, Establishing plants by transplanting and interseeding, in Monsen, S.B., Stevens, R., and Shaw, N.L., compilers, Restoring western ranges and wildlands: U.S. Forest Service, Rocky Mountain Research Station, Fort Collins, Colorado, General Technical Report RMRS-GTR136-vol-3, p. 739-744.

U.S. Forest Service, 2014, Field guide for managing cheatgrass in the southwest: U.S. Forest Service, Southwestern Region, TP-R3-16-04, Albuquerque, New Mexico, 7 p.

Whisenant, S.G., 1999, Repairing damaged wildlands-A process-oriented, landscape-scale approach: New York, Cambridge University Press.

Williams, B. K., Szaro, R.C., and Shapiro, C.D., 2009, Adaptive management-The U.S. Department of the Interior technical guide: Washington, D.C., Adaptive Management Working Group, U.S. Department of the Interior.

Wirth, T.A., and Pyke, D.A., 2007, Monitoring post-fire vegetation rehabilitation projects - A common approach for non-forested ecosystems: U.S. Geological Survey Scientific Investigations Report 2006-5048, 36 p. 


\section{Appendix A. Generalized State and Transition Models}

The following are five generalized state and transition models that span the Great Basin, Columbia and Snake River regions of the sagebrush biome (from Miller and others, 2014). These represent the following: (fig. A1) Mesic/aridic Wyoming big sagebrush in an 8-12 in. (203-305 mm) precipitation zone (PZ); (fig. A2) cool mesic to warm frigid/xeric big sagebrush 12-14 in. (305-356 mm) PZ; (fig. A3) cool mesic to cool frigid/xeric mountain big sagebrush in a 12-14 in. (305-356 mm) PZ; (fig. A4) cool frigid/xeric mountain big sagebrush with piñon pine and juniper 12-14 in. or greater (305-356 mm or greater) PZ; and (fig. A5) Cryic/xeric mountain big sagebrush/mountain brush in a 14 in. or greater (356 mm or greater) PZ. Large rectangles illustrate states that are comprised of community phases (smaller rectangles). Transitions among states are shown with arrows starting with T; restoration pathways are shown with arrows starting with R. The "at risk" community phase is most vulnerable to transitions to an alternate state.

Mesic/aridic

Wyoming big sagebrush (8-12 inch precipitation zone)

Low to moderate resilience and low resistance

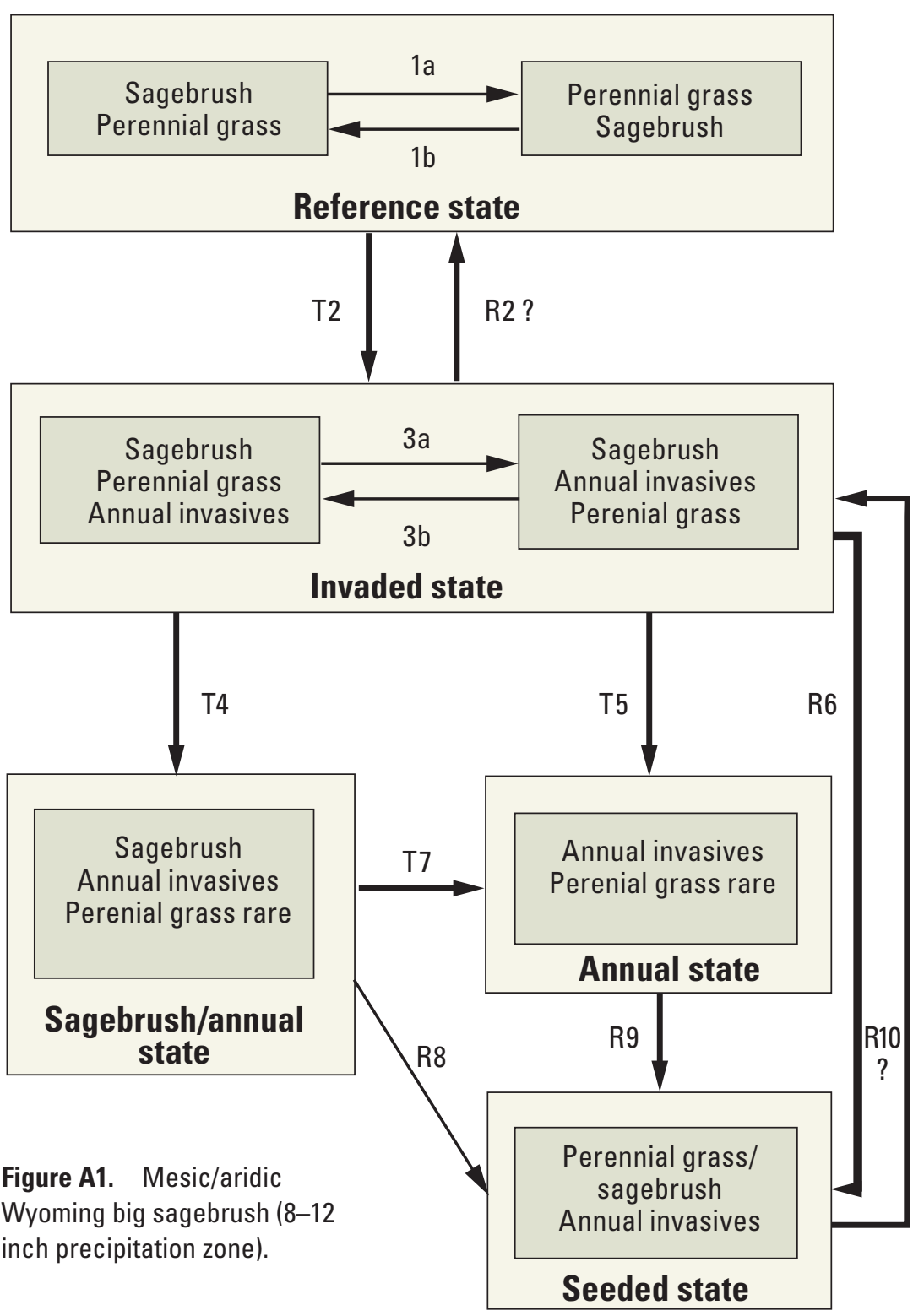

(1a) Perennial grass increases due to disturbances that decrease sagebrush, like wildfire, insects, disease, and pathogens.

(1b) Sagebrush increases with time.

(T2) An invasive seed source and/or improper grazing trigger an invaded state.

(R2) Proper grazing, fire, herbicides, and/or mechanical treatments are unlikely to result in return to the reference state on all but the coolest and wettest sites.

(3a) Perennial grass decreases and both sagebrush and invasives increase with improper grazing. Decreases in sagebrush due to insects, disease, or pathogens can further increase invasives.

(3b) Proper grazing and herbicides or mechanical treatments that reduce sagebrush may restore perennial grass and decrease invaders on wetter sites (10-12 inches). Outcomes are less certain on drier sites (8-10 inches) and/or with low perennial grass. (T4) Improper grazing triggers a largely irreversible threshold to a sagebrush/annual state.

(T5 and T7) Fire or other disturbances that remove sagebrush result in an annual state. Perennial grass is rare and recovery potential is low due to low precipitation, mesic soil temperatures, and competition from annual invasives. Repeated fire can cause further degradation.

(R6, R8, and R9) Seeding following fires and/or invasive species control results in a seeded state. Sagebrush may recolonize depending on patch size, but annual invasives are still present.

(R10) Seeding effectiveness and return to the invaded state are related to site conditions, seeding mix, an post-treatment weather. 
Cool mesic to warm frigid/xeric

Big sagebrush (12-14 inch precipitation zone)

Piñon pine and/or juniper potential

Moderate resilience and moderately low resistance

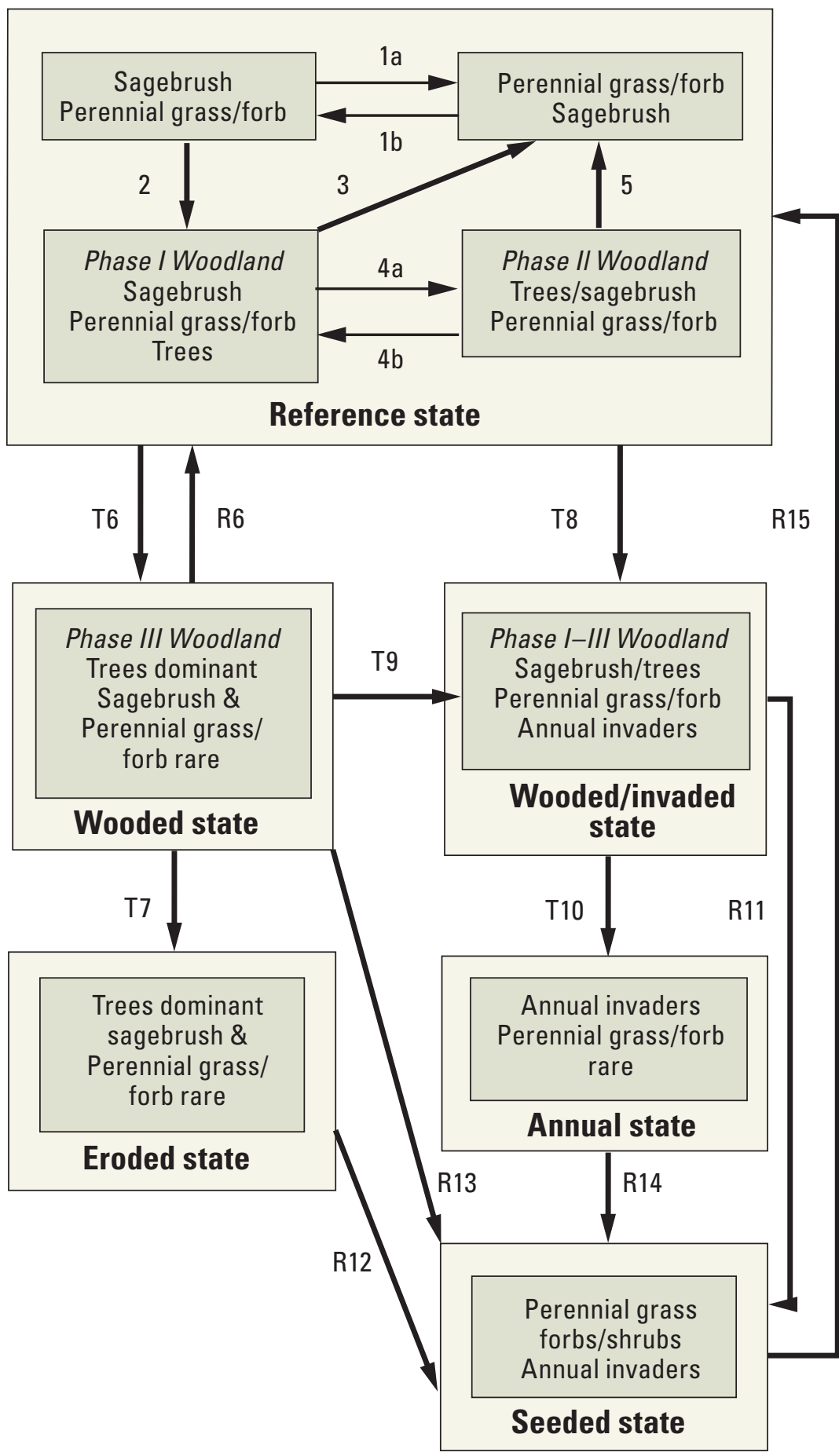

(1a) Disturbances such as wildfire, insects, disease, and pathogens result in less sagebrush and more perennial grass/forb.

(1b) Sagebrush increases with time.

(2) Time combined with seed sources for piñon and/or juniper trigger a Phase 1 Woodland.

(3 and 5) Fire and/or fire surrogates (herbicides and/or mechanical treatments) that remove trees may restore perennial grass/forb and sagebrush dominance on cooler/wetter sites. On warmer/drier sites with low perennial grass/forb abundance resistance to invasion is moderately low.

(4a) Increasing tree abundance results in Phase II Woodlland with depleted perennial grass/forb and shrubs.

(4b) Fire surrogates (herbicides and/or mechanical treatments) that remove trees may restore sagebrush and perennial grass/forb dominance.

(T6) Infilling of trees and improper grazing can result in biotic threshold crossing to a wooded state with increased risk of high severity crown fires.

(R6) Fire, herbicides and/or mechanical treatments that remove trees may restore perennial grass/forb and sagebrush dominance on cooler/wetter sites.

(T7) An irreversible abiotic threshold crossing to an eroded state can occur depending on soils, slope, and understory species.

(T8 and T9) An invasive seed source and/or improper grazing can trigger a wooded/invaded state.

(T10) Fire or other disturbances that remove trees and sagebrush can result in a biotic threshold crossing to annual dominance on warmer/drier sites with low resilience. (R11, R12, R13, and R14) Seeding after fire and/or invasive species control increases perennial grass/forb. Sagebrush may recolonize depending on seed sources, but annual invaders are still present. Seeded eroded states may have lower productivity. (R15) Depending on seed mix, grazing, and level of erosion, return to the reference state may occur on cooler and wetter sites if an irreversible threshold has not been crossed.

Figure A2. Cool mesic to warm frigid/xeric big sagebrush (12-14 inch precipitation zone). 
Cool mesic to cool frigid/xeric

Mountain big sagebrush (12-14 inch precipitation zone)

Moderate resilience and resilience

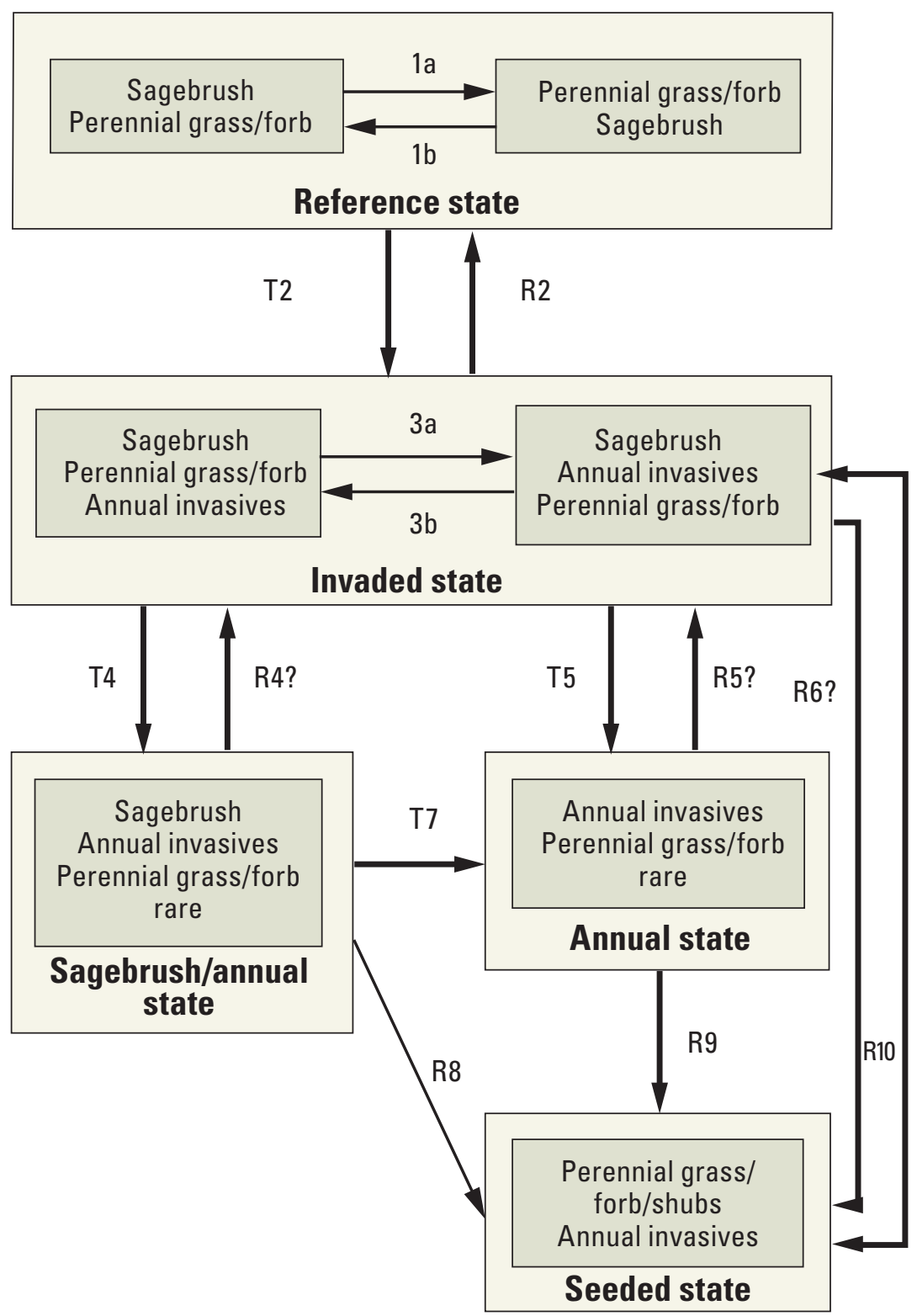

(1a) Perennial grass/forb increases due to disturbances that decrease sagebrush, like wildfire, insects, disease, and pathogens.

(1b) Sagebrush increases with time.

(T2) An invasive seed source and/or improper grazing trigger an invaded state.

(R2) Proper grazing, fire, herbicides, and/or mechanical treatments may restore perennial grass/forb and sagebrush dominance with few invasives.

(3a) Perennial grass/forb decreases and sagebrush and invasives increases with improper grazing by livestock. Decreases in sagebrush due to insects, disease, or pathogens can further increase invasives.

(3b) Proper grazing, herbicides, or mechanical treatments that reduce sagebrush may increase perennial grass/forb and decrease invasives.

(T4) Improper grazing results in a sagebrush/annual state.

(R4) Proper grazing may facilitate return to the invaded state on cooler/wetter sites if sufficient grass/forb remains.

(T5 and T7) Fire or other disturbances that remove sagebrush result in an annual state. Perennial grass/forb are rare and recovery potential is reduced. Repeated fire can result in a biotic threshold crossing to annual dominance on warmer/drier sites, and root-sprouting shrubs may increase.

(R5) Cooler and wetter sites may return to the invaded or reference state with lack of fire, proper grazing, and favorable weather. (R6, R8, and R9) Seeding following fires and/or invasive species control results in a seeded state. Sagebrush may recolonize depending on patch size, but annual invaders are still present.

(R10) Cooler and wetter sties may return to the invaded or possibly reference state depending on seeding mix, grazing, and weather.

Figure A3. Cool mesic to cool frigid/xeric mountain big sagebrush (12-14 inch precipitation zone). 


\section{Cool frigid/xeric}

Mountain big sagebrush (12-14 inch or greater precipitation zone)

Piñon pine and/or juniper potential

Moderate high resilience and resilience

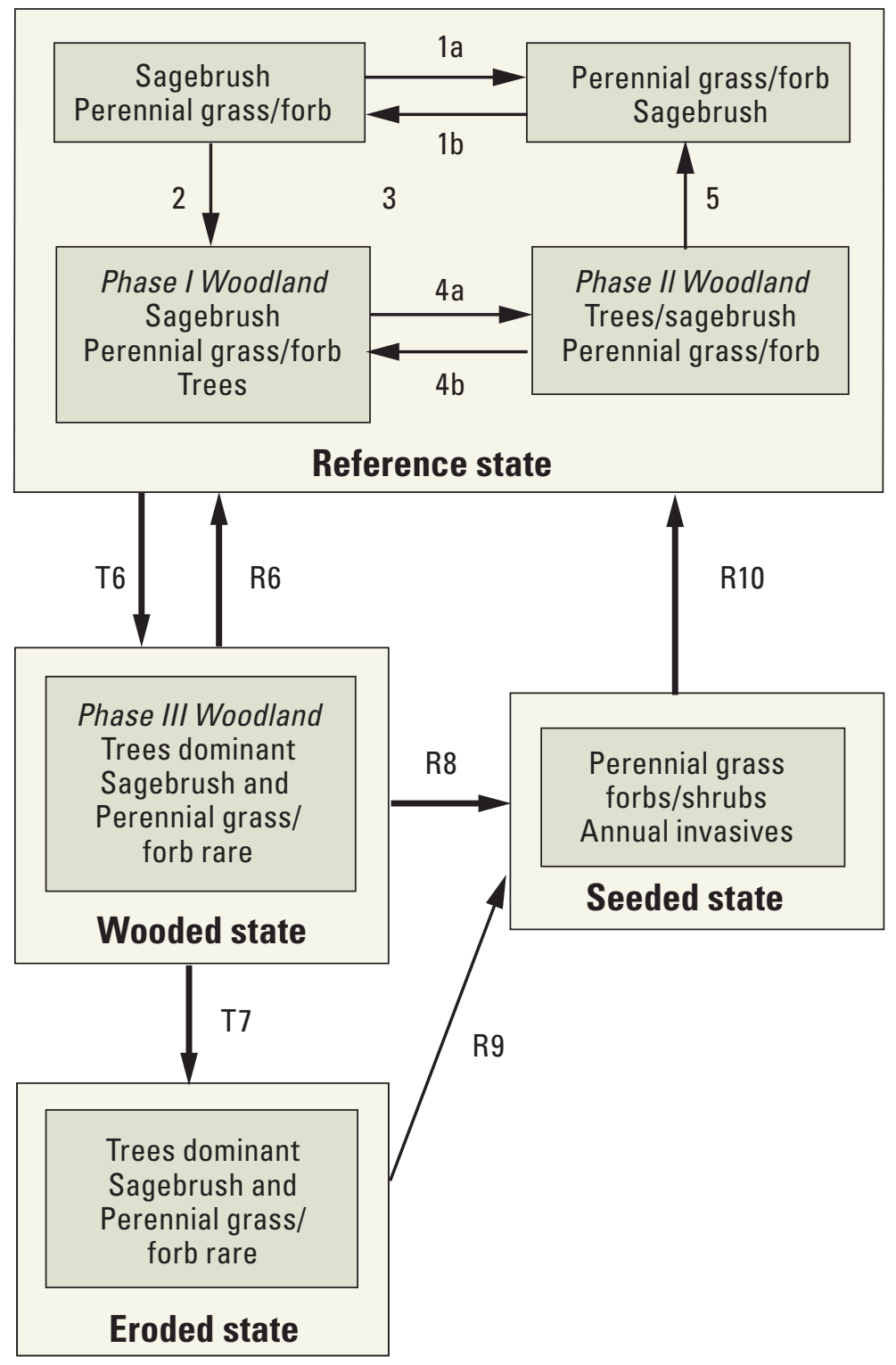

(1a) Disturbances such as wildfire, insects, disease, and pathogens result in less sagebrush and more perennial grass/forb.

(1b) Sagebrush increases with time.

(2) Time combined with seed sources for piñon and/or juniper trigger a Phase 1 Woodland.

(3 and 5) Fire and/or fire surrogates (herbicides and/or mechanical treatments) that remove trees may restore perennial grass/forb and sagebrush dominance.

(4a) Increasing tree abundance results in a Phase II Woodlland with depleted perennial grass/forb.

(4b) Fire surrogates (herbicides and/or mechanical treatments) that remove trees may restore sagebrush and perennial grass/forb and sagebrush dominance.

(T6) Infilling of trees and/or improper grazing can result in a biotic threshold crossing to a wooded state with increased risk of high severity crown fires.

(R6) Fire, herbicides, and/or mechanical treatments that remove trees may restore perennial grass/forb and sagebrush dominance.

(T7) An irreversible abiotic threshold crossing to an eroded state can occur depending on soils, slope, and understory species.

(R8 and R9) Seeding after fire may be required on sites with depleted perennial grass/forb, but seeding with aggressive introduced species can decrease native perennial grass/forb. Annual invasives are typically rare. Seeded eroded states may have lower productivity.

(R10) Depending on seed mix and grazing, return to the reference state may be possible if an irreversible threshold has not been crossed.

Figure A4. Cool frigid/xeric mountain big sagebrush (12-14 inch or greater precipitation zone). 
Cryic/xeric mountain big sagebrush/ Mountain brush (14 inch or greater precipitation zone) Moderate high resilience and high resilience

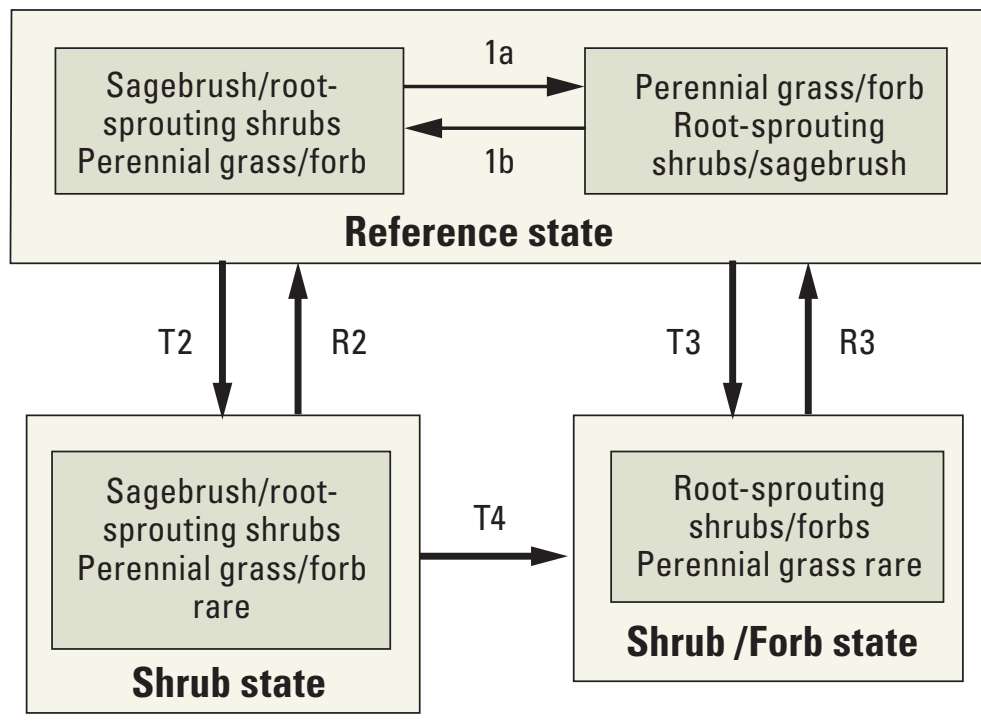

(1a) Perennial grass/forb increases due to disturbances that decrease sagebrush, like wildfire, insects, disease, and pathogens.

(1b) Sagebrush and other shrubs increase with time.

(T2) Improper grazing triggers a shrub dominated state.

(R2) Proper grazing results in a return to the reference state.

(T3 and T4) Fire or other disturbances that remove sagebrush result in dominance by root-sprouting shrubs and an increase in native forbs like lupines. (R3) Proper grazing and time result in return to the reference state.

Note: Resilience is lower on the cold cryic sites due to short growing seasons.

Figure A5. Cryic/xeric mountain big sagebrush/mountain brush (14 inch or greater precipitation zone). 
56 Restoration Handbook for Sagebrush Steppe Ecosystems with Emphasis on Greater Sage-Grouse Habitat—Part 3 


\section{Appendix B. Score Sheet for Pre-Treatment Site Resilience to Disturbance and Resistance to Invasive Annual Grasses in Sagebrush Steppe}

This score sheet is from Miller and others (2014, appendix 8). The first page describes the variables and potential scores for each variable. The second page is a blank form that may be copied for determining pre-treatment site resilience and resistance for each ecological site. Note that two to five plots should be scored to evaluate each ecological site in the restoration area depending on the size and variability across the area. Plots can vary in size but should be small enough to easily observe vegetation composition and structure by standing at one point or walking a short distance (about $100 \mathrm{ft}$ $[30.48 \mathrm{~m}])$. 


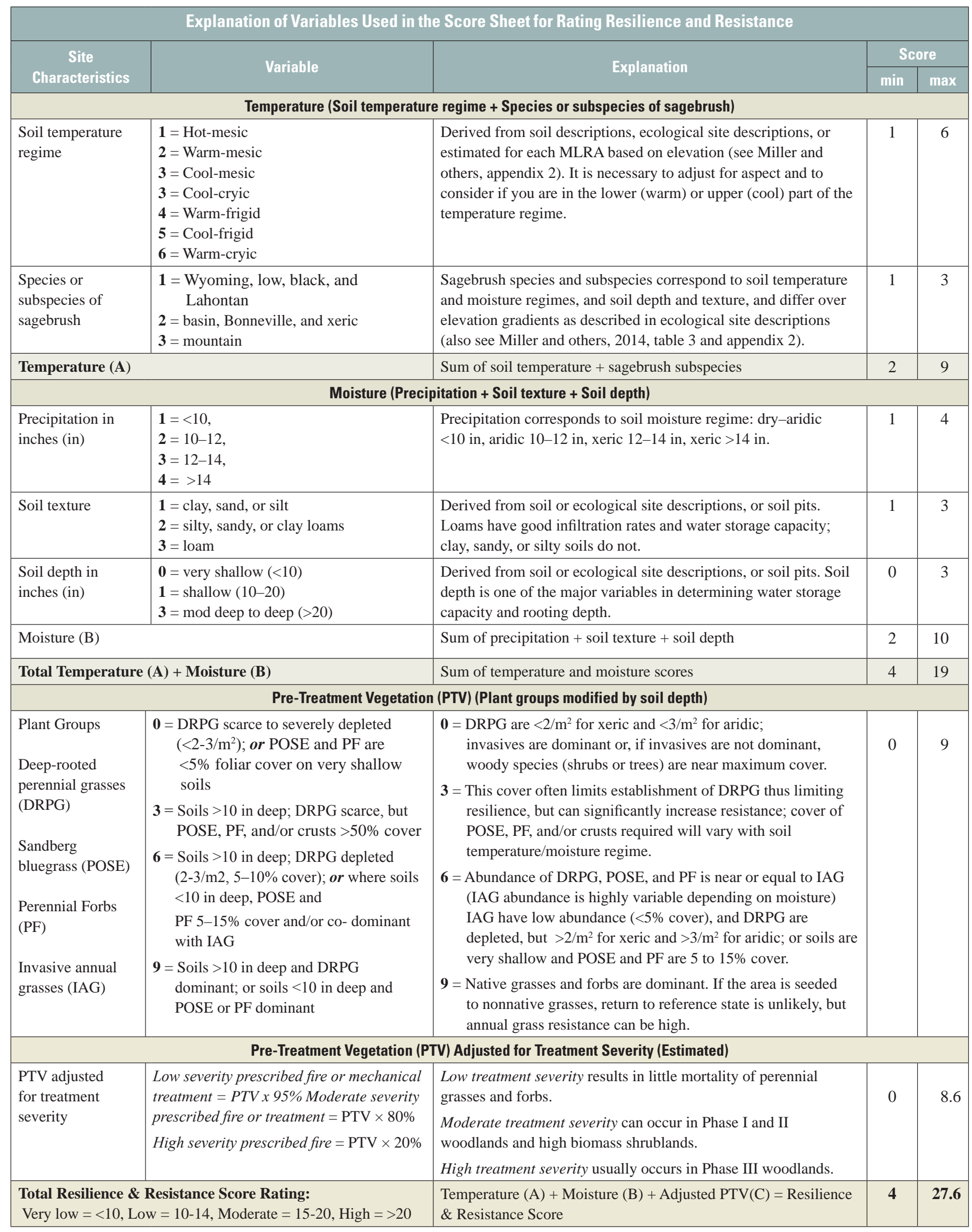




\begin{tabular}{|c|c|c|c|c|c|c|}
\hline \multicolumn{7}{|c|}{ Score Sheet for Rating Resilience to Disturbance and Resistance to Invasive Annual Grasses in the Great Basin } \\
\hline \multicolumn{2}{|c|}{$\begin{array}{l}\text { E cological Site or Type Name: } \\
\text { \% Area: } \\
\text { (Use ecological site descriptions or guidelines for the MLRA with field assessment to complete score sheet.) }\end{array}$} & \multicolumn{5}{|c|}{$\begin{array}{l}\quad \text { PL OT SCORE }{ }^{1} \\
\text { (Sample two to five plots } \\
\text { per ecological site depending } \\
\text { on size and variability of area.) }\end{array}$} \\
\hline SITE CHARACTERISTICS & SCORE FOR VARIABLE & 1 & 2 & 3 & 4 & 5 \\
\hline \multicolumn{7}{|c|}{ Temperature (Soil temperature regime + Species or subspecies of sagebrush) } \\
\hline Soil temperature regime & $\begin{aligned} \mathbf{1} & =\text { hot }- \text { mesic } \\
\mathbf{2} & =\text { warm-mesic } \\
\mathbf{3} & =\text { cool-mesic }, \text { or cool-cryic (resilience is low but } \\
& \quad \text { resistance is high) } \\
\mathbf{4} & =\text { warm-frigid } \\
\mathbf{5} & =\text { cool-frigid } \\
\mathbf{6} & =\text { warm-cryic }\end{aligned}$ & & & & & \\
\hline Species or subspecies of sagebrush & $\begin{array}{l}\mathbf{1}=\text { Wyoming, low, black, or Lahontan } \\
\mathbf{2}=\text { basin, Bonneville, or xeric } \\
\mathbf{3}=\text { mountain }\end{array}$ & & & & & \\
\hline \multicolumn{2}{|l|}{ A. Temperature Score = } & & & & & \\
\hline \multicolumn{7}{|c|}{ Moisture (Precipitation + Soil texture + Soil depth) } \\
\hline Precipitation in inches (in) & $\begin{array}{l}\mathbf{1}=<10 \\
\mathbf{2}=10-12 \\
\mathbf{3}=12-14 \\
\mathbf{4}=>14\end{array}$ & & & & & \\
\hline Soil texture & $\begin{array}{l}\mathbf{1} \text { = clay, sand, or silt } \\
\mathbf{2} \text { = silty, sandy, or clay loam } \\
\mathbf{3} \text { = loam }\end{array}$ & & & & & \\
\hline Soil depth in inches (in) & $\begin{array}{l}\mathbf{0}=\text { very shallow }(<10) \\
\mathbf{1}=\text { shallow }(10-20) \\
\mathbf{3}=\text { moderately deep to deep }(>20)\end{array}$ & & & & & \\
\hline \multicolumn{2}{|l|}{ B. M oisture Score = } & & & & & \\
\hline \multicolumn{2}{|l|}{ Temperature Score (A)+ M oisture Score (B) } & & & & & \\
\hline \multicolumn{7}{|c|}{ Pre-Treatment Vegetation (PTV) (Plant groups modified by soil depth) } \\
\hline $\begin{array}{l}\text { Plant G roups: } \\
\text { Deep-rooted perennial grasses (DRPG) } \\
\text { (potentially dominant in shallow to deep } \\
\text { soils }>10 \text { in) } \\
\text { Sandberg bluegrass (POSE) (potentially } \\
\text { dominant in very shallow soils }<10 \text { in) } \\
\text { Perennial forbs (PF) } \\
\text { Invasive annual grasses (IAG) }\end{array}$ & $\begin{aligned} \mathbf{0}= & \text { DRPG and POSE scarce to severely depleted (DRPG } \\
& <2-3 / \mathrm{m}^{2} \text { and/or less than } 5 \% \text { foliar cover) } \\
\mathbf{3}= & \text { DRPG on soils }>10 \text { in deep scarce, but POSE or PF are } \\
& >50 \% \text { foliar cover (resistance may be relatively high but } \\
& \text { resilience is low) } \\
\mathbf{6}= & \text { DRPG on soils }>10 \text { in deep depleted }\left(2-3 / \mathrm{m}^{2} \text { or about }\right. \\
& 5-10 \% \text { foliar cover), and } / \text { or co-dominant with IAG; or } \\
& \text { on soils }<10 \text { in deep, POSE and PF } 5-15 \% \text { foliar cover } \\
& \text { and co-dominant with IAG } \\
\mathbf{9}= & \text { DRPG and PF dominant on soils }>10 \text { in deep; or } \\
& \text { POSE and PF dominant on soils }<10 \text { in deep. }\end{aligned}$ & & & & & \\
\hline \multicolumn{7}{|c|}{ Pre-Treatment Vegetation (PTV) Adjusted for Treatment Severity (Estimated) } \\
\hline $\begin{array}{l}\text { C. Adjusted Pre-Treatment Vegetation } \\
\text { (Estimate fire severity by plot based on } \\
\text { fuels and burn prescription; estimate } \\
\text { mechanical treatment severity by plot } \\
\text { based on woody species biomass.) }\end{array}$ & $\begin{array}{l}\text { Low severity prescribed fire or mechanical treatment }= \\
\text { PTV } \times 95 \% \\
\text { Moderate severity prescribed fire or mechanical treatment }= \\
\text { PTV } \times 80 \% \\
\text { High severity prescribed fire }=\text { PTV } \times 20 \%\end{array}$ & & & & & \\
\hline \multicolumn{2}{|c|}{ Total R esilience \& R esistance Score = Temperature (A) + Moisture (B) + Adjusted PTV(C) } & & & & & \\
\hline \multicolumn{7}{|c|}{ Resilience \& R esistance R ating: Very low $=<10$, L ow $=10-14$, M oderate $=15-20, \mathrm{H}$ igh $=>20$} \\
\hline
\end{tabular}

${ }^{1}$ The plot should represent a plant community and fit within one ecological site. It can vary in size but should be small enough to easily observe vegetation composition and structure by standing at one point or walking a short distance (approximately $100 \mathrm{ft}$ ). 


\section{Appendix C. Calibration of a Seed Drill}

The purpose of this document is to provide information for how to calibrate a rangeland drill. Three methods are described: (1) wheel circumference; (2) seed per row-foot; (3) small bag per land area. These are repeated with metric units after the U.S. Customary units.

\section{Basic Adjustments to the Seed Boxes}

1. The seeding rate control for the cool season grain box is on the back of the seed box.

2. The derailleur speed changer for the fluffy/chaffy seed box is on the front left-hand side of the drill.

3. The small seed rate control for the small seed box is on the front left-hand corner of the seed box.

\section{Calculating the B ulk Seeding R ate per Acre}

Bulk seeding rate $(\mathrm{lb})$ per acre $=$ (pure live seeding rate $(\mathrm{lb})$ per acre $\div$ (percent of pure live seed per bulk pound (decimal).

Percent of pure live seed per bulk pound = germination $($ decimal $) \times$ purity $($ decimal $) \times 100$.

\section{Performing the Wheel Circumference M ethod}

1. Calculate the bulk seeding rate per seed drop.

Bulk seeding rate per seed drop $=($ bulk seeding rate $(\mathrm{lb})$ per acre $) \times($ acres in simulated run $) \div$ (number of seed drops on drill)

Acres in simulated run $=($ drill planting width $(\mathrm{ft})) \times($ simulated run $(\mathrm{ft})) \div\left(43,560 \mathrm{ft}^{2}\right.$ per acre $)$

2. Park the drill on a nearly level surface with the tires blocked.

3. Jack the end wheel or the drive wheel up on a traditional drill. Use the calibration wheel on a minimum- till drill.

4. On each drill, disconnect two seed hoses, one on the left side and one on the right side of the seed box being calibrated.

5. Place collection containers under each of these seed drops and fill the seed box with the planting mix.

6. Determine the number of revolutions the traditional drill's end wheel or the minimum-till drill's calibration wheel needs to be turned to simulate a $100-\mathrm{ft}$ (or other selected distance) run.

Wheel revolutions $=($ simulated run $(\mathrm{ft})) \div($ wheel circumference $(\mathrm{ft}$ and tenths $))$

7. Simulate a run of the drill (keep the drill stationary) by turning the end wheel or calibration wheel so seed moves through the drill.

8. Collect and weigh the seed. Compare this weight to the amount of bulk seed you want the drill to the amount delivered. Adjust and recalibrate if necessary.

\section{Performing the Seed per R ow-F oot M ethod}

1. The seeding rate control for the cool season grain box is on the back of the seed box.

Seeds per row foot $=($ seeds per square foot $) \times($ row width $(\mathrm{ft}))$

Seeds per square foot $=$ (seeds per acre $) \div\left(43,560 \mathrm{ft}^{2} /\right.$ acre $)$

Row width $=$ (planting width of the drill $(\mathrm{ft}) \div$ (number of rows planted)

2. Attach the drill to a tractor and fill the seed boxes with the planting mix.

3. Pull the drill to make sure seeds are flowing.

4. Pull the drill over a firm surface for several feet. Count the total number of seeds that were dropped in 4 or $5 \mathrm{ft}$ of a row and calculate the average number of seeds per row foot. Compare this result to the amount of seed you want the drill to deliver. Adjust and recalibrate if necessary.

\section{Performing the Small Bag per L and A rea M ethod}

1. Calculate the bulk seeding rate for the test run.

Bulk seeding rate for test run (lb) $=$ (bulk seeding rate (lb) per acre) $\times$ (acres in test run)

2. Calculate the pounds of seed remaining after the test run.

Pounds of seed remaining after the test run = (bulk seeding rate (lb) per acre) - (the bulk seeding rate (lb) for the test run)

3. Fill the seed boxes with enough seed mix to plant 1 acre.

4. Select a sample area to drill and drill 0.25 acre.

5. Stop and vacuum the remaining seed from the seed boxes and weigh it. Compare this weight to the weight of seed that should be left in the drill after drilling 0.25 acre. Adjust and recalibrate, if necessary. 


\section{M etric Units}

\section{Calculating the Bulk Seeding R ate per Hectare}

Bulk seeding rate $(\mathrm{kg})$ per hectare $(\mathrm{ha})=$ (pure live seeding rate $(\mathrm{kg})$ per hectare $\div$ (percent of pure live seed per bulk kilogram (decimal).

Percent of pure live seed per bulk kilogram $=$ germination $($ decimal $) \times$ purity $($ decimal $) \times 100$.

\section{Performing the Wheel Circumference $M$ ethod}

1. Calculate the bulk seeding rate per seed drop.

Bulk seeding rate per seed drop $=($ bulk seeding rate $(\mathrm{kg})$ per hectare $) \times($ hectares in simulated run $) \div($ number of seed drops on drill)

Hectares in simulated run $=($ drill planting width $(\mathrm{m})) \times($ simulated run $(\mathrm{m})) \div\left(10,000 \mathrm{~m}^{2} /\right.$ hectare $)$

2. Park the drill on a nearly level surface with the tires blocked.

3. Jack the end wheel or the drive wheel up on a traditional drill. Use the calibration wheel on a minimum-till drill.

4. On each drill, disconnect two seed hoses, one on the left side and one on the right side of the seed box being calibrated.

5. Place collection containers under each of these seed drops and fill the seed box with the planting mix.

6. Determine the number of revolutions the traditional drill's end wheel or the minimum-till drill's calibration wheel needs to be turned to simulate a $100-\mathrm{m}$ (or other selected distance) run.

Wheel revolutions $=($ simulated run $(\mathrm{m})) \div($ wheel circumference $(\mathrm{m}$ and tenths $))$

7. Simulate a run of the drill (keep the drill stationary) by turning the end wheel or calibration wheel so seed moves through the drill.

8. Collect and weigh the seed. Compare this weight to the amount of bulk seed you want the drill to deliver. Adjust and recalibrate if necessary.

\section{Performing the Seed per R ow-M eter M ethod}

1. The seeding rate control for the cool season grain box is on the back of the seed box.

Seeds per row meter $=($ seeds per square meter $) \times($ row width $(\mathrm{m}))$

Seeds per square $\mathrm{m}=$ (seeds per hectare $) \div\left(10,000 \mathrm{~m}^{2}\right.$ per ha)

Row width $=$ (planting width of the drill $(\mathrm{m}) \div$ (number of rows planted $)$

2. Attach the drill to a tractor and fill the seed boxes with the planting mix.

3. Pull the drill to make sure seeds are flowing.

4. Pull the drill over a firm surface for several meters. Count the total number of seeds that were dropped in 1 or $2 \mathrm{~m}$ of a row and calculate the average number of seeds per row meter. Compare this result to the amount of seed you want the drill to deliver. Adjust and recalibrate if necessary.

\section{Performing the Small Bag per L and Area M ethod}

1. Calculate the bulk seeding rate for the test run. Bulk seeding rate for test run $(\mathrm{kg})=($ bulk seeding rate $(\mathrm{kg})$ per hectare $) \times($ hectares in test run)

2. Calculate the kilograms of seed remaining after the test run. Kilograms of seed remaining after the test run = (bulk seeding rate $(\mathrm{kg})$ per acre) - (the bulk seeding rate $(\mathrm{kg})$ for the test run)

3. Fill the seed boxes with enough seed mix to plant 1 hectare.

4. Select a sample area to drill and drill 0.25 hectares.

5. Stop and vacuum the remaining seed from the seed boxes and weigh it. Compare this weight to the weight of seed that should be left in the drill after drilling 0.25 acre. Adjust and recalibrate, if necessary. 
Publishing support provided by the U.S. Geological Survey Science Publishing Network, Tacoma Publishing Service Center

For more information concerning the research in this report, contact the Director, Forest and Rangeland Ecosystem Science Center U.S. Geological Survey

777 NW 9th St., Suite 400

Corvallis, Oregon 97330

http://fresc.usgs.gov 


\section{兽}

흠

욱

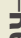

:

흥

. 